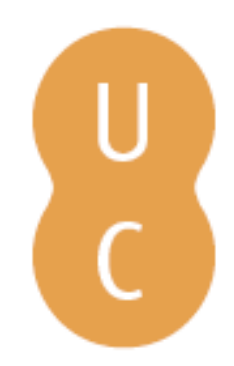

\title{
pompalina
}

\section{Crianças e jovens nas vidas de Plutarco}

Autor(es): $\quad$ Soares, Carmen; ed. lit.

Publicado por: Centro de Estudos Clássicos e Humanísticos da Universidade de

Coimbra; Imprensa da Universidade de Coimbra

URL

persistente: URI:http://hdl.handle.net/10316.2/5611

DOI: $\quad$ DOI:http://dx.doi.org/10.14195/978-989-721-004-4

Accessed : $\quad$ 26-Apr-2023 11:16:51

A navegação consulta e descarregamento dos títulos inseridos nas Bibliotecas Digitais UC Digitalis, UC Pombalina e UC Impactum, pressupõem a aceitação plena e sem reservas dos Termos e Condições de Uso destas Bibliotecas Digitais, disponíveis em https://digitalis.uc.pt/pt-pt/termos.

Conforme exposto nos referidos Termos e Condições de Uso, o descarregamento de títulos de acesso restrito requer uma licença válida de autorização devendo o utilizador aceder ao(s) documento(s) a partir de um endereço de IP da instituição detentora da supramencionada licença.

Ao utilizador é apenas permitido o descarregamento para uso pessoal, pelo que o emprego do(s) título(s) descarregado(s) para outro fim, designadamente comercial, carece de autorização do respetivo autor ou editor da obra.

Na medida em que todas as obras da UC Digitalis se encontram protegidas pelo Código do Direito de Autor e Direitos Conexos e demais legislação aplicável, toda a cópia, parcial ou total, deste documento, nos casos em que é legalmente admitida, deverá conter ou fazer-se acompanhar por este aviso.

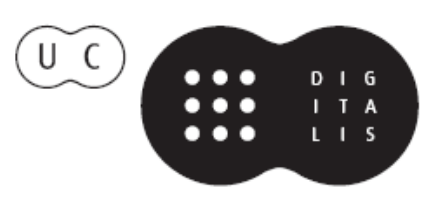


Colecção Autores Gregos e Latinos Série Ensaios

\section{Carmen Soares}

\section{CRIANÇAS E JOVENS nas Vidas de Plutarco}


Carmen Soares

Universidade de Coimbra

\section{Crianças e jovens nas Vidas de Plutarco}


Todos os volumes desta série são sujeitos a arbitragem científica independente.

\title{
Coordenaçáo: Carmen Soares
}

Título: Crianças e jovens nas Vidas de Plutarco

\section{Editor: Centro de Estudos Clássicos e Humanísticos IMPRENSA DA UNIVERSIDADE DE COIMBRA} EDIÇÃO: 1a/2011

\begin{abstract}
Coordenador Científico do Plano de Edição: Maria do Céu Fialho Conselho editorial: José Ribeiro Ferreira, Maria de Fátima Silva, Francisco de Oliveira, Nair Castro Soares

Director técnico da colecçấo: Delfim F. Leấo Concepção gráfica e paginaçấo: Rodolfo Lopes, Nelson Henrique
\end{abstract}

\author{
OBRA REALIZADA NO ÂMBITO DAS ACTIVIDADES DA UI\&D \\ Centro de Estudos Clássicos e Humanísticos \\ Universidade de Coimbra \\ FaCUldade de Letras \\ Tel.: 239859981 | Fax: 239836733 \\ 3000-530 CoImbra
}

ISBN: 978-989-721-003-7

ISBN DigitaL: 978-989-721-004-4

Depósito Legal: 337930/11

DOI: http://dx.doi.org/10.14195/978-989-721-004-4

Obra Publicada com o Apoio de:

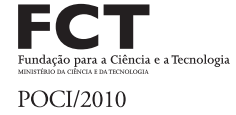

(C) IMPRenSA DA UniversidAde De CoImbra

(C) Classica Digitalia Vniversitatis Conimbrigensis (http://classicadigitalia.uc.pt)

( ) Centro de Estudos Clássicos e Humanísticos da Universidade de Coimbra

Reservados todos os direitos. Nos termos legais fica expressamente proibida a reprodução total ou parcial por qualquer meio, em papel ou em edição electrónica, sem autorização expressa dos titulares dos direitos. É desde já excepcionada a utilização em circuitos académicos fechados para apoio a leccionação ou extensão cultural por via de $e$-learning. 


\section{ÍNDICE}

$\begin{array}{ll}\text { Nota Prévia } & 7\end{array}$

$\begin{array}{ll}\text { INTRODUÇÃO } & 13\end{array}$

NOMENCLATURA PARA DESIGNAR CRIANÇAS E JOVENS

Metodologia das VIDAS No TRATAMENTO Da INFÂNCIA E JUVENTUde 26

Retrato Físico $\quad 29$

Retrato Psicológico 39

$\begin{array}{ll}\text { EDUCAÇÃO } & 61\end{array}$

CONTEÚDOS FORMATIVOS $\quad 64$

EDUCADORES

$\begin{array}{ll}\text { LOCAIS DE FORMAÇÃO } & 101\end{array}$

$\begin{array}{lr}\text { ObservaÇốes Finais } & 109\end{array}$

$\begin{array}{ll}\text { BibLIOGRAFIA } & 113\end{array}$

ÍNDICE ONOMÁSTICO 123

$\begin{array}{ll}\text { ÍNDICE DAS VIDAS } & 129\end{array}$ 


\section{Nota Prévia}

A reflexão sobre o retrato das crianças e jovens nas Vidas de Plutarco deriva de um gosto pessoal pelo estudo de "figuras menores" nas fontes para o conhecimento da História Antiga. Dentro desta rubrica inserem-se as figuras geralmente menos retratadas, as supra referidas, além da 'mãe' e do 'pai', ou seja a mulher e o homem no papel que desempenham no seio da dinâmica familiar ${ }^{1}$. Esse estatuto relativamente discreto que os escritores consagram no relato dos feitos humanos aos anos que antecedem a idade adulta em muito dificulta o conhecimento actual sobre a história da família no

${ }^{1} \mathrm{O}$ relacionamento entre pais e filhos na produção literária de Plutarco é um assunto que já abordei repetidas vezes; cf. Soares 2004, 2005, 2006 a, 2006 b, 2007 a, 2007 b, 2007 c, 2009. 
Mundo Grego e Romano. Se tivermos em conta apenas as fontes escritas, é necessário esperar precisamente por Plutarco para encontrarmos obras exclusivamente dedicadas a esses "pequenos" protagonistas das futuras façanhas do homem pleno, o adulto livre, cidadão da polis grega ou da civitas latina. Estou naturalmente a referir-me aos tratados morais Da educação das crianças e Sobre o Afecto aos Filhos ${ }^{2}$. Aí encontramos seguramente uma série de informaçóes preciosas para uma reflexão alargada sobre o tema da infância e juventude no mundo greco-romano.

No entanto, o desafio que encetamos de momento não visa o tratamento que o Autor consagrou à temática em textos essencialmente focalizados na questão em apreço, por me parecer que esta informação está mais acessível ao leitor e estudioso moderno, precisamente por ser objecto concreto de reflexão nas referidas obras. Pareceu-me mais útil enveredar por uma sistematização da abordagem dispersa que lhe dá ao longo das suas inúmeras Vidas Paralelas ${ }^{3}$.

${ }^{2}$ Ambos já traduzidos para português, o primeiro por Pinheiro (2008) e o segundo por mim (Soares 2010).

3 Que as Vidas e as Obras Morais formam um todo, cuja separação em dois blocos é uma convenção recente na história da transmissáo dos textos, é um dado que a própria unidade temática do conjunto da produção confirma. Aliás, o VII Congresso da International Plutarch Society subordinou-se precisamente a esse assunto, ao eleger por tema The Unity of Plutarch's Work, como se pode confirmar pela publicação das respectivas actas (Nikolaidis 2008 a). 
As edições usadas são as de K. Ziegler, Plutarchi Vitae Parallelae. Leipzig, Teubner, 1959-2002. As remissóes para passos das Vidas são feitas ao seu título em latim, abreviado e seguido do(s) número(s) do(s) respectivo(s) capítulo(s) e/ou parágrafo(s).

Considerando que o público deste trabalho pode desconhecer as línguas clássicas, optei por acompanhar o idioma original por traduçóes (colocadas entre aspas simples) e, nos casos em que os nomes gregos têm um sentido de linguagem técnica especializada (como é, entre outros, o caso da terminologia das faixas etárias), pela transliteração dos mesmos para caracteres latinos (apresentada em itálico). Assim, a título de exemplo, para a palavra 'criança', registam-se, além dos termos originais $\pi \alpha \tilde{\mathrm{l}}$ ( (gr.) e puer (lat.), a forma pais, transliterada do grego para o alfabeto latino.

Embora tenha seguido as abreviaturas adoptadas pelo Greek-English Lexikon de H. G. Liddell e R. Scott para os títulos das Vidas citadas, elenco de seguida a correspondência entre aquelas e as respectivas traduçóes em português, por forma a agilizar a identificação das mesmas:

Aem. $=$ Emílio Paulo
Ages. $=$ Agesilau
Agis $=$ Ágis
Alc. $=$ Alcibiades
Alex. $=$ Alexandre
Ant. $=$ Marco António

Arat.$=$ Arato

Arist. $=$ Aristides

Brut. $=$ Marco Bruto

$C G=$ Gaio Graco

Caes. $=$ César

Cam. $=$ Camilo 
Cat. Ma. = Catão Censor

Cat. Mi. = Catão de Útica

Cic. = Cícero

Cim. $=$ Cimon

Cleom. $=$ Cleómenes

Com. Cim. Luc. = Comparação entre Címon e Luculo

Cor. = Coriolano

Dem. $=$ Demóstenes

Demetr. $=$ Demétrio

Dio = Dion

Eum. = Eumenes

Fab. = Fábio Máximo

Galb. = Galba

Luc. = Luculo

Lyc. = Licurgo

Lys. = Lisandro

Mar. = Gaio Mário

Marc. = Marcelo

Nic. $=$ Nicias

Num. = Numa

Pel. = Pelópidas

Per. $=$ Péricles

Phil. $=$ Filopémen

Phoc. $=$ Fócion

Pom. = Pompeio

Pyrrh. = Pirro

Rom. $=$ Rómulo
Sert. $=$ Sertório

Sol. = Sólon

Sull. = Sula

$T G=$ Tibério Graco

Them. = Temistocles

Thes. = Teseu

Tim. = Timoleonte 
Quanto à bibliografia indicada no final deste estudo, distinguem-se duas secçôes: uma consagrada às edições, traduçóes e comentários; a outra aos estudos. $\mathrm{Na}$ primeira, os títulos são elencados por ordem cronológica crescente; na segunda, o critério de apresentaçáo seguido foi a tradicional ordenação alfabética. Os títulos das revistas estão abreviados, de acordo com a nomenclatura estabelecida pelo índice bibliográfico L'Année Philologique. 


\section{INTRODUÇÃO}

\section{Nomenclatura para designar crianças e jovens}

Por inerência temática do género literário em apreço, a leitura de uma obra de natureza biográfica cria nos seus leitores a expectativa legítima de abordar a vida de uma pessoa desde o nascimento até à morte. No período de tempo, de amplitude variável, que vai da infância à idade adulta ou, na melhor das hipóteses, à velhice, o indivíduo passa por um processo de desenvolvimento psico-somático que deu azo à divisão do ciclo da vida em diversas etapas. Da leitura desses passos, em que escritores gregos e latinos identificam entre três a sete fases distintas da vida do ser humano, chegamos à seguinte conclusão: não concordância ao nível quer da designação quer das barreiras etárias estabelecidas para cada uma das etapas (Golden 1990: 12-22, Eyben 1996: 80-82, Harlow and Laurence 2002: 15-17, Rawson 2003: 134-145, Ferreira 2010: 142-148). A reflexão que nos propomos fazer incide, naturalmente, apenas sobre as duas principais etapas em que se divide a vida antes da chegada à idade adulta, habitualmente designadas 'infância' e 'juventude'.

${ }^{1}$ A discussão em torno das faixas etárias evidencia de tal forma a dificuldade em encontrar (porque não o há) um único termo para cada etapa, que, recentemente surgiu a designação "emerging 
Em termos metodológicos, a nossa pesquisa partiu do levantamento das ocorrências nas Vitae das palavras empregues por Plutarco para referir crianças e jovens. Para podermos ter uma visão prévia da multiplicidade de vocábulos de que dispunha o autor e dos sentidos a eles associados iremos considerar os passos que melhor ajudam ao esclarecimento semântico das palavras em questão, cujos nomes transliterados do grego para latim são: brephos, nepios, paidion, paidarion, pais, antipais, meirakion, neos, neanias, neaniskos, ephebos. $\mathrm{O}$ primeiro esclarecimento a fazer é que nem todos os termos apresentam um sentido unívoco. De facto, conforme veremos de seguida, para designar uma mesma realidade, o autor dispóe, na maioria dos casos, de várias palavras.

Brephos (pl. brephe) significa sempre 'bebé, conforme atestam os passos em que o termo é referido: aos gémeos recém-nascidos, Rómulo e Remo (Rom. 2. 7 , 3. 5, 4. 1, 2 e 4, 6. 1); à criança que a rainha, viúva do rei espartano Polidectes, está para dar à luz (Lyc. 3. 3; mais exactamente, uma vez que se refere a uma criança ainda no ventre materno, brephos pode também traduzir-se por 'feto'); aos cuidados prestados pelas amas da Lacónia aos bebés que criam (Lyc. 16. 4); aos bebés das mães

adulthood" para a fase em que se insere o adolescente e o jovem adulto (Arnett 2004). Com base nas distinçôes que encontramos nas Vidas, continuamos a preferir separar adolescentes de jovens adultos, embora ambos projectem já as expectativas de se passar à maturidade. 
espartanas (Lyc. 17. 8); ao filho de Catão Censor, que a esposa lava e enfaixa (Cat. Ma. 20. 4); ao recém-nascido filho de Pompeio e neto de Júlio César (Caes. 23. 6).

Nepios (pl. nepia) cobre um significado mais amplo, que poderíamos designar por 'criança pequena', pois vem aplicado tanto com o sentido de 'bebé' como de 'criança de tenra idade'.

Quanto ao primeiro significado, atesta-se nas referências: aos gémeos amamentados pela loba (Rom. 21. 8); a Dioniso, o deus recém-nascido, lavado pelas amas depois do parto (Lys. 28. 7). Neste caso é um sinónimo de brephos.

O entendimento de 'criança de tenra idade' deduzse de forma inequívoca sobretudo dos passos em que é usado com sentido adjectival (a) ou como sinónimo de substantivo com esse mesmo valor (b). Assim acontece quando:

a) ao diminutivo paidia ('criancinhas') Plutarco adiciona o adjectivo nepia, para identificar os filhos que as Sabinas carregam nos braços (Rom. 19. 2) - ou seja, um nepios é uma 'criança de colo'; o substantivo tekna (pl. de teknon, 'filho') vem qualificado de nepia (Cam. 21. 1) ou determina este neutro do plural substantivado

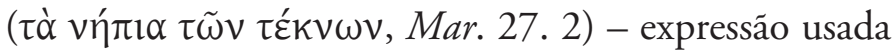
para significar 'filhos pequenos'; a palavra nepios ajuda a clarificar o sentido que se quer dar ao termo mais impreciso pais (Sull. 37. 6; Luc. 31. 3);

b) Pirro vem referido, no mesmo passo (Pyrrh. 2. 1), como nepios e paidion que necessita dos cuidados de amas. 
Paidion (pl. paidia), tratando-se de um diminutivo formado a partir de pais e do sufixo -ion, é um sinónimo dos dois vocábulos anteriormente considerados, brephos e nepios.

Significa 'bebé', valor evidente: no seu emprego, no mesmo passo, em alternância com brephos (Rom. 2.

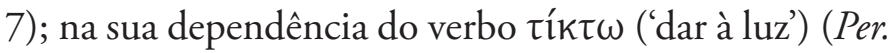
1. 1 ; Pom. 53. 5).

O sentido 'criança pequena' reforça-se de várias maneiras: a sua junção, já assinalada, a nepion (Rom. 19. 2) ou ao adjectivo mikron ('pequeno') (Ages. 25. 11; Brut. 31. 4); a sua utilização, no mesmo trecho, como sinónimo de nepios (Aem. 33. 6) ou do diminutivo 'filhinha' (Өuүó́tpiov, Aem. 10. 6); a referência de que paidia são crianças 'que se carregam ao colo' (Cor. 33. 4) ou que a mãe pode pendurar ao seu pescoço (Brut. 31. 5).

Paidarion (pl. paidaria), outro diminutivo da palavra pais, não só cobre os campos semânticos de paidion, mas também designa crianças mais velhas.

Que se refere a bebés, atestam-no o facto de se aplicar: aos gémeos Rómulo e Remo, quando foram expostos (Rom. 8. 2); ao recém-nascido, órfão do rei Polidectes e sobrinho de Licurgo (Lyc. 3. 5); aos bebés espartanos, cuja robustez física e consequente direito à vida eram avaliados por um conselho de anciáos da respectiva tribo ( $L y c$. 16. 1); aos filhos de escravos amamentados pela mulher de Catão (Cat. Ma. 20. 5); 


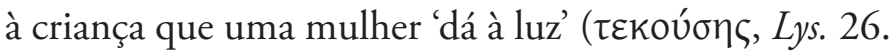

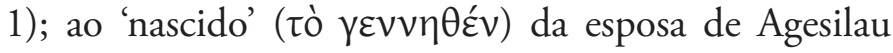
(Ages. 3. 1).

Também o sentido 'criança pequena' decorre da junção ao adjectivo 'pequeno' ( $\mu$ ıkpóv, Cat. Mi. 3. 8) e à indicação de que tinha força suficiente para bater no pedagogo (Lyc. 30. 7). Claro que nenhuma destas duas últimas ocorrências nos permite advogar um tecto máximo para a idade de um paidarion.

Contudo, os trechos que de seguida passamos a indicar parecem sugerir que a designação incluiria crianças mais velhas do que todas aquelas que já referimos, pois são capazes de levar a cabo as seguintes tarefas: fugir do acampamento inimigo e levar aos compatriotas informações preciosas para lhes levantar a moral (Luc. 9. 7); participar em combate naval, conduzindo pequenas embarcaçóes, das quais lançam insultos provocatórios aos adversários (Nic. 24. 1); arrastar um cadáver pela cidade, promovendo o ultraje público do defunto (Dio 35.6).

Pais (pl. paides) apresenta-se como o vocábulo de utilização polissémica por excelência. A verdade é que funciona de sinónimo para todos os restantes termos usados na denominação dos indivíduos que se encontram na infância e juventude.

Um dos sentidos mais abrangentes é o de 'filho de’ $^{2}$. Dentro dessa aplicação de carácter genérico,

${ }^{2} \mathrm{O}$ termo pais é largamente usado com esse sentido ao longo 
constatamos o seu uso para significar 'aquele que ainda não é um homem adulto ('óvńp)', como se o ciclo da vida se dividisse em três períodos principais: aquele em que se é pais, o de aner e o do geron ('anciáo'). A propósito da valentia exibida pelo espartano Ísidas durante o ataque surpresa dos Tebanos (Ages. 34. 9), Plutarco afirma que a fase da vida em que os seres humanos atingem o apogeu da perfeição (à letra: 'fazem

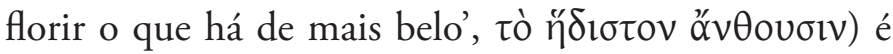
quando passam de paides a andres. A mesma dicotomia crianças/adultos ressalta da Vida de Fócion (cap. 7. 3), quando, após a morte do amigo Cábrias, o protagonista toma a seu cargo a missão de educar o órfăo Ctesipo, de modo a fazê-lo passar de 'menino' (

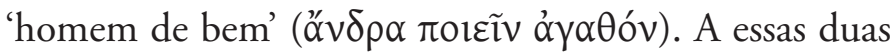
fases há que juntar a derradeira, a da velhice, tripartição que Plutarco sugere quando, a propósito da participação dos líderes romanos na guerra (Marc. 1. 5), afirma que

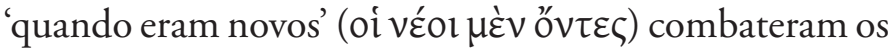
Cartagineses na Sicília, 'quando estavam na maturidade'

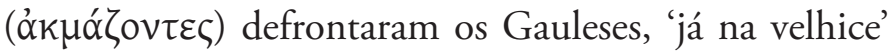

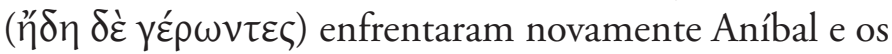
Cartagineses.

das Vitae. Aparece com regularidade nos capítulos de abertura, em que se apresenta a genealogia da personagem biografada. Como esclarece Golden (1990) 15: "When it does not mean "child of", it refers to a male child before his enrollement in a deme and his consequent entry into civil life, and (less strictly) to a female child before her corresponding change in status, her marriage". Os rapazes rondariam os 17/18 anos. 
Contudo, é frequente considerar-se haver uma subdivisão no período que antecede a idade adulta e a velhice. Veja-se a observação feita a propósito da beleza física de Alcibíades (Alc. 1. 4), constante em todas as idades e fases do seu crescimento, referidas pela seguinte sequência: pais, meirakion, aner e 'outono' ( $\mu \varepsilon \tau o ́ \pi \omega \rho o v)$. Em termos de idades, as quatro etapas elencadas correspondem a 'infância', 'juventude', 'idade adulta' e 'velhice'. A mesma sequência de idades, com a exclusão da última, reaparece, desta feita, em Alex. 11. 6.

Ao nível da preparação física dos jovens no domínio da luta havia uma distinção relacionada com a faixa etária. Como se lê na Vida de Eumenes (cap. 1. 2), o pancrácio, certamente por ser mais violento, era praticado pelos mais velhos, os meirakia ( $\pi \alpha \gamma \kappa \rho \alpha ́ \tau ı \alpha$

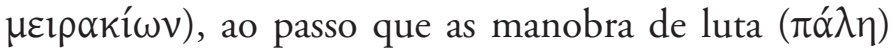
podiam ser executadas pelos mais novos, os paides ( $\pi \alpha \lambda \alpha i ́ \sigma \mu \alpha \tau \alpha \pi \alpha i \delta \omega \nu)$.

Quando é que se passa a baliza cronológica da infância para se entrar na juventude é uma pergunta para a qual as Vidas de Plutarco não oferecem uma resposta categórica, mas revelam as concepçôes gerais na época. Enquanto é pais (tradução grega para a palavra latina puer), a criança romana usa uma toga com uma faixa púrpura (toga praetexta) e traz pendurada ao pescoço a bulla (Sert. 14. 4) $)^{3}$ O abandono desses dois

${ }^{3}$ Este amuleto, que acompanhava a criança ao longo da sua infância, corresponde, como se diz na Vida de Rómulo (20.4), a um 
adereços conotados com a infância e a substituição por uma nova veste (toga virilis), toda branca, assinalam o ritual de passagem à juventude. Segundo a tradição grega, a passagem de uma etapa à outra assinalavase inscrevendo o nome do menino no treino militar obrigatório, a ephebia, momento a partir do qual ele passa a ser um ephebos ${ }^{4}$. Como observa Rawson (2003: 142) a propósito do costume romano, não havia uma data fixa para se proceder a essa passagem, que se daria, geralmente, entre os 13 e os 18 anos. Os pais eram livres de escolher o momento mais oportuno e de assinalálo de acordo com as suas posses ${ }^{5}$. Também a passagem da juventude à idade adulta se caracteriza pela mesma variação quanto à identificação de uma idade exacta para tal se dar. Já referimos que, com 20 anos, Alexandre é chamado tanto de pais como de meirakion (Alex. 11. 6). Com a mesma idade, Augusto assume o consulado, concessão extraordinária para quem 'não passava de um

'acessório parecido com uma bolha que usavam à volta do pescoço' (Leão-Fialho 2008: 152). Ou seja, o nome advém-lhe da forma de bulla ('bolha'). Plutarco fala deste mesmo objecto em Questóes Romanas 101.

${ }^{4}$ A tradição grega e a romana vêm mencionadas lado a lado, ambas impostas pelo mesmo progenitor ou tutor, Marco António, a dois adolescentes: Antilo, nascido da união do romano com Fúlvia, e Cesarião, filho de Cleópatra e César (Ant. 71. 3).

${ }^{5}$ Dependendo das posses dos progenitores, o final da infância podia ser assinalado com maior ou menor magnitude. De acordo com a vida de luxo e opulência extravagantes que leva no Egipto, Marco António comemora a integração dos jovens Antilo e Cesariáo no mundo dos adultos promovendo, durante muitos dias, simpósios, cortejos e festins em Alexandria (Ant. 71. 3). 
meirakion' (Brut. 27. 3). Do ponto de vista legal, "o jovem romano era (...) um menor até ter completado os 25 anos" (Eyben 1981: 329). Aliás, mesmo na vida pública, um jovem tinha de esperar pelos 27 anos (a partir de 180 a. C., segundo a Lex villia annalis), pelos 30 (sob o governo de Sula) ou 25 (a partir de Augusto), ou seja, por ser 'adulto', para poder iniciar a sua carreira política, o chamado cursus honorum (Eyben 1981: 332). Havia, no entanto, excepçóes à regra, conforme atesta o já referido caso do próprio Augusto ${ }^{6}$.

Antipais (pl. antipaides), formado pela junção do prefixo anti- ('contra, diante de, em vez de') ao substantivo pais, refere-se ao indivíduo que se encontra no limiar da meninice, i. e., que deixou de ser menino há pouco tempo, aquele a quem se costuma chamar 'adolescente' (Aem. 22. 4; Pom. 76. 7; Cic. 7. 7; Dio 55. 4).

Um trecho da Vida de Filopémen (cap. 1. 2) não deixa dúvidas quanto a um antipais situar-se na faixa etária que segue a infância. De facto alude-se a uma formação de carácter filosófico (ministrada por dois discípulos da Academia, Ecdelo e Demófanes), conhecimento a que teria acesso não uma 'criança' (pais), mas alguém que está 'à frente/para lá da meninice', um antipais.

${ }^{6}$ Cf. Harlow and Laurence 2002: 104-116, para uma análise detalhada das mudanças ocorridas na idade e na ordem das magistraturas entre os sécs. II a. C.-I A. D. 
Meirakion (pl. meirakia), como vimos supra (Alc. 1. 4), corresponde a um substantivo empregue para significar 'jovem'.

Atributo principal dessa idade é a força física

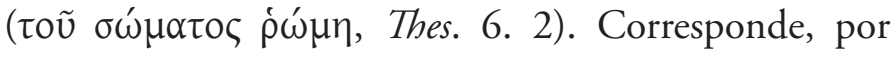
conseguinte, à fase da vida em que se inicia a carreira militar (Cor. 3. 1), por volta dos 17 anos (Cat. Ma. 1. 8). É, por tudo isso, a altura em que o indivíduo está

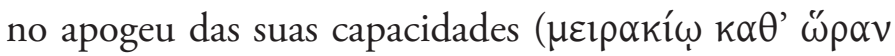

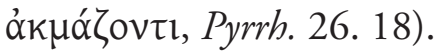

Embora não possamos estabelecer barreiras cronológicas fixas para o início e final da juventude, a verdade é que Plutarco nos fornece alguns números precisos. Apelida de meirakion o jovem Augusto com os seus 20 anos (Brut. 27. 3) e Catáo Censor, tanto aos 17 (como acabámos de referir) como aos 25 (Cat. Ma. 2. 3) ${ }^{7}$. Claro que jovens que combatem e comandam com sucesso, como é o caso das duas personalidades acabadas de referir e de muitas outras, acabam por ser

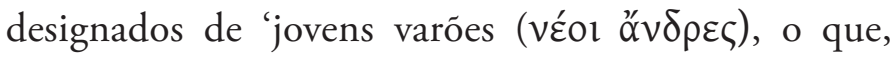
em contexto militar, é sinonimo de 'soldados'. Entre outros exemplos, atestam essa acepção os seguintes passos:

- Cic. 45. 1-2: Augusto é simultaneamente apelidado de meirakion e 'jovem varão (véov ớv $\delta \rho \alpha$ );

- Phil. 7. 5: Filopémen inspira brio militar em

${ }^{7}$ Idade calculada pela indicação de que Catáo Censor (nascido em 234 a. C.) era um meirakion quando Fábio Máximo tomou Tarento (em 209 a. C., no decurso da Segunda Guerra Púnica). 


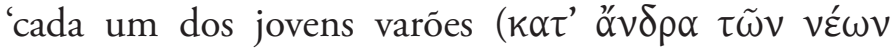
ह̌ $\kappa \alpha \sigma \tau O V)$;

- Caes. 45. 3: a cavalaria de Pompeio é apelidada

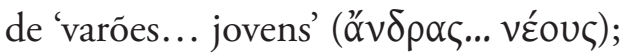

- Arat. 36. 5: Cleómenes, por contraste com o seu adversário, Arato, encontra-se no apogeu do vigor, daí que seja apresentado como 'um varão audacioso e

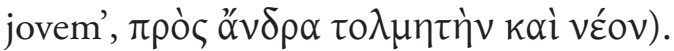

Neos (masc. pl. neoi) também pode surgir com a indicação precisa da idade do 'jovem', caso de Demétrio (Demetr. 5. 3), filho de Antígono da Macedónia, que, com 22 anos, apesar de 'jovem e inexperiente' (vÉo

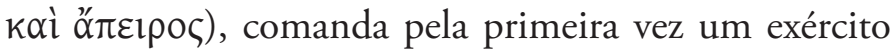
contra um 'homem adulto' (ảv $\delta \rho i ́)$, Ptolomeu. O presente trecho deixa perceber que a oposição entre os dois adversários se processa não só por se encontrarem em lados contrários do conflito, mas também em termos etários. $\mathrm{O}$ vencido não passa de um neos, enquanto o vencedor já se encontra na fase seguinte, a do aner.

Entre as numerosas ocorrências do adjectivo neos, destacamos aquelas em que a palavra é escolhida nitidamente para se contrapor a 'anciáo', tanto na forma presbyteros (Aem. 39. 8; Mar. 46. 7; Agis 6. 1-2; Cleom. 12. 4; Nic. 11. 3; Pom. 8. 3 e 5; Alex. 53. 1), como geron (Cic. 46. 1; Nic. 12. 1). Entre os sinónimos de neos, encontram-se dois termos também eles de sentido equivalente, o já referido meirakion (Cim.4.4) e neanias (Cic. 46. 2). 
Neanias (substantivo da família do adjectivo neos) e/ou o respectivo diminutivo, neaniskos (pl. neaniskoi), formas recorrentes para designar 'jovem', servem frequentemente de sinónimos a outras palavras com o mesmo significado: meirakion (Mar. 14. 5-6; Arat. 6. 4-5; CG 16. 1-2; Cam. 15. 3-4; Phoc. 20. 1, 4) e neos (Cat. Ma. 22. 2-3).

Também relativamente a neaniskos, tanto pode ser sinónimo do vocábulo genérico para 'filho', i. e., pais (Pyrrh. 30. 6-7), como temos passos que atestam tratar-se de um termo distinto daquele, e, neste caso, designa precisamente a etapa que antecede a do pais (Aem. 33. 6: neaniskoi e paides são identificados como elementos distintivos que integram um mesmo cortejo sacrificial), e a que a sucede, a do aner (Cat. Ma. 22. 4: Carnéades, filósofo académico, e o estóico Diógenes, apresentados como andres gregos que despertam enorme entusiasmo entre os 'jovens' neaniskoilneoi - de Roma). Ainda dentro da mesma linha de confronto com palavras de sentido diverso, note-se que, tal como sucede com o termo neos, neaniskos designa 'jovem' por contraste com 'anciāo', presbyteros (Lyc. 12. 12).

Ephebos (pl. epheboi) corresponde à fase imediatamente a seguir à infância, conforme vimos a propósito da referência à passagem de Cesarião de pais a ephebos (Ant. 71. 3) e segundo confirmam diversos passos em que se distinguem epheboi de paides (Pel. 33. 5; Phil. 16. 8; Pom. 40. 3; Cat. Mi. 13. 1; Arat. 53. 6). 
Por volta dos 18 anos os rapazes iniciavam a preparação militar, que durava geralmente dois anos. Não obstante a evoluçáo por que passou a formação conhecida por ephebia, tratou-se sempre de um período probatório, findo o qual o jovem era considerado apto a desempenhar uma das principais funçóes próprias de um cidadão no esplendor das suas forças físicas: ser soldado.

Ou seja, em termos práticos, enquanto os epheboi são aqueles que se preparam para vir a combater, os neaniskoi são jovens soldados (Phil. 11. 2; Aem. 17. 3; Fab. 22. 3; Thes. 26. 3 e 5-7; Pyrrh. 30. 6, 33. 2; Phoc. 7. 4). Apesar dessa distinçáo clara (que também se faz relativamente a outra palavra usada para significar 'jovem', neos: Cleom. 2. 2), epheboi e neaniskoi, devido à necessidade de se manterem em excelente forma física, frequentam o mesmo espaço destinado aos exercícios, o 'pórtico' ( $\sigma \tau o \alpha ́)$, uma parte coberta ou galeria pertencente ao recinto do ginásio (Cim. 16. 5)8 .

A este vasto leque de termos usados para designar os indivíduos, é preciso acrescentar duas expressóes que designam as noçôes abstractas 'infância' e 'juventude'.

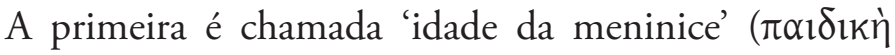

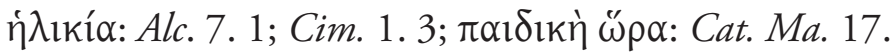

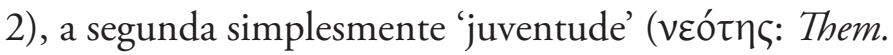
2. 7; Comp. Cim. Luc. 1. 4; Cic. 10. 4; Marc. 1. 4).

Do ponto de vista sociológico fica de fora do nosso estudo uma análise exaustiva do universo feminino,

${ }^{8}$ Cf. infra, rubrica intitulada "Locais de formação". 
exclusão que se impóe justificar. $\mathrm{O}$ material sobre o qual nos debruçámos, as Vidas, determinou como natural essa nossa opção. De facto, sendo do sexo masculino todos os protagonistas da mais de meia centena de biografias, as referências à infância e juventude de mulheres é bastante secundária?. Pelo que as nossas referências a meninas e donzelas serão esporádicas.

\section{Metodologia das Vidas no tratamento da infância e juventude}

Apesar de, na sua totalidade, o número de passos em que se fala de crianças e jovens andar pelas centenas, não espere o leitor desprevenido encontrar nas Vidas uma abordagem sistemática do assunto. Não só as referências podem figurar em qualquer momento da narração (se bem que, por razóes cronológicas, sejam mais recorrentes nos capítulos iniciais), como dizem respeito quer ao biografado, quer a outros indivíduos.

Em termos do tipo de informação fornecida, o estudo que fazemos é mais de natureza sociológica do que ética. Ou seja, buscámos dados relativos à condição da criança e do jovem na sociedade em que se insere. Sendo assim, não nos interessou enveredar por uma análise do

9 Sobre a mulher em Plutarco, vd.: Le Corsu (1981), Nikolaidis (1997) e (2008 b), Stadter (1999), Walcot, (1999), Castellani (2002), McInerney (2003). Como observa Golden (1990: 3), o interesse dos autores em assinalar as diferenças entre crianças e adultos é um factor responsável por colocar num segundo plano a caracterizaçáo da identidade feminina das crianças. 
texto dentro do texto (que consideraria o carácter e os actos das crianças e jovens como parte da heurística da respectiva Vida), mas do texto dentro do seu contexto (que permite perceber uma visão da infância e juventude aos olhos de um escritor greco-romano do séc. II A. D.).

Consequentemente, a imagem que as Vidas de Plutarco nos permitem delinear desses dois períodos iniciais da existência de uma pessoa está condicionada não só pela bagagem cultural do autor, mas por um princípio de natureza metodológica por ele perfilhado o princípio da selectividade qualitativa. Como na Vida de Alexandre (1.2), a narração que faz não relata todos os feitos famosos dos homens em apreço (método próprio da história), mas dá conta sobretudo de factos (que podem nem ser os mais ilustres), ditos ou anedotas que revelem o seu carácter (método próprio do género biográfico).

Conforme sugere o trecho referido, o princípio da selectividade qualitativa aplica-se a cada uma das Vidas considerada no seu conjunto. Plutarco consegue ser um pouco mais específico sobre esse princípio, aplicando-o precisamente às duas fases principais em que se divide a vida de um homem, a idade adulta e o período que a precede. Tal como um atleta, a partir do momento que obtém um prémio na categoria de adulto ( $\left(\mathcal{\varepsilon} \vee \alpha^{\prime} v \delta \rho \alpha \sigma\right)$ ), deixa de falar das suas vitórias na

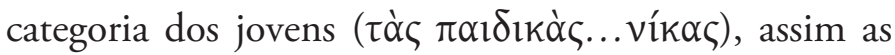
façanhas realizadas na juventude, não obstante a sua excepcionalidade, acabam por ser obscurecidas pelo elevado número e grandiosidade das provas e guerras posteriores (Pom. 8. 7). O mesmo é dizer que, apesar de 
a juventude poder apresentar-se como um período fértil em dados biográficos, estes podem ser sacrificados, para dar espaço ao relato dos feitos da maturidade.

Para além destes condicionalismos de ordem metodológica, Plutarco via os seus conhecimentos sobre a infância e juventude das figuras biografadas limitados pelas próprias fontes. Segundo advoga Pelling (1990: 216), a abundância ou carência de dados sobre esses períodos da vida dependem do que as fontes revelavam. Pelo que, continua o estudioso, quando o autor não fala de determinado aspecto é porque ele não constava da fonte disponível e não por omissão deliberada.

Considerando que a análise onomástica dos vocábulos relativos à infância e juventude revelou que um mesmo termo (pais) designa um indivíduo desde que nasce até aos 24 anos e que, não obstante alguns aspectos exclusivos de cada uma das idades, os dois períodos de tempo confrontam o indivíduo com algumas realidades similares, não optámos por iniciar por uma reflexão tradicional, bipartida em infância e juventude. Em vez disso, preferimos individualizar dois aspectos marcantes da identidade psico-somática do indivíduo nessas duas fases da vida: o retrato físico e o retrato psicológico ${ }^{10}$.

10 Para uma síntese sobre a produção bibliográfica mais importante e recente sobre um tema tão rico e vasto como infância e juventude em geral, veja-se a introdução e a vasta bibliografia final de Cohen and Rutter (2007). 
Retrato Físico 


\section{Retrato Físico}

Mesmo antes de nascer, a condição física do bebé pode ser um dos aspectos tidos em conta nas considerações do nosso Autor. Ao que parece, a dieta da mãe durante a gravidez influencia a constituição do feto. Uma alimentação frugal (ỏyoorıía) é a chave para dar à luz bebés 'magros, mas perfeitos e bonitos' (Lyc. 17. 8). Aliás este ponto podia ser tâo vital que, entre os Espartanos, a boa constituição e a robustez do recém-nascido eram requisitos determinantes para garantir a sobrevivência do mesmo (Lyc. 16. 1). O conselho de anciáos que decidia sobre o direito à vida da criança determinava a exposição precisamente com base nesse critério físico. Um bebé que fosse 'indesejado' ${ }^{1} \mathrm{e}$

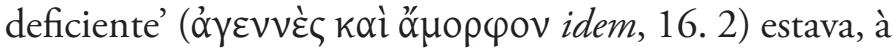
partida, condenado a morrer ${ }^{2}$.

Ter boa figura e vigor constituem características físicas recorrentemente mencionadas também a

${ }^{1}$ Traduzo por 'indesejado' o adjectivo que, à letra, significa 'mal nascido, de vil nascimento'.

${ }^{2}$ Que haveria excepçóes, nomeadamente ao nível da linhagem real, atesta-o o facto de o rei Agesilau II ser coxo (Ages. 2. 3). Quanto ao relato de Plutarco a propósito da inspecção dos bebés pelo conselho da tribo e eventual infanticídio, vd. Huys (1996) 48-56. Sobre a exposiçâao e abandono de bebés no mundo grego e romano em geral, vd. Russel (1943), Patterson (1985), Harris (1994), Haentjens (2000), Corbier (2001) e Ingals (2002). 
propósito das crianças e dos jovens, mas não dos velhos.

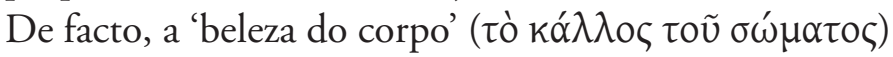
é um atributo que, de regra, não vigora na velhice. Com o passar dos anos 'a beleza de um pais morre' (Arist. 2. 4). A excepção que confirma a regra encontra-a Plutarco em Alcibíades, dotado de 'beleza natural e perfeição física' (Alc. 1. 4), ao longo de toda a vida. Quanto ao vigor físico, por duas vezes, em contextos semelhantes - o cortejo fúnebre de um general grego (Pelópidas) e de um romano (Emílio Paulo) - aquele atributo vem atestado ao afirmar-se é a quem tem mais força e simboliza a pujança da vida que cabe carregar pesos e homenagear o defunto. No primeiro caso são 'jovens e

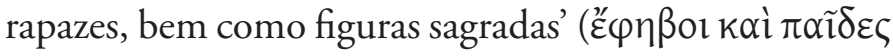

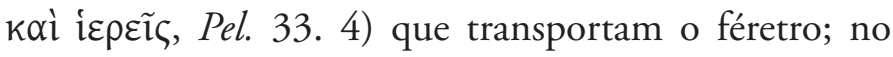
segundo é mais óbvia a alusão à força, uma vez que Plutarco escreve que é 'quem possui corpos robustos e os

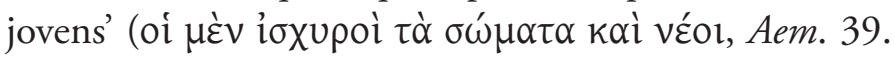

8) que carrega o féretro, por contraste com os anciáos (oi $\delta \dot{\varepsilon} \pi \rho \varepsilon \sigma \beta u ́ \tau \varepsilon \rho o 1)$, que seguem o defunto invocando os seus títulos de glória.

Aliás, as referências à beleza e à força tanto figuram no texto como mais um elemento da caracterização dos indivíduos, como comportam uma importância causal na história. Quanto à indicação de que um pais é belo, sem que dessa característica física decorra qualquer implicação nos acontecimentos da história, refira-se: a aparência bela de Cleónimo, por quem se enamorou

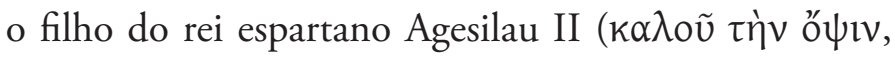
Ages. 25. 1), também ele outrora apaixonado por um 
rapaz de beleza extraordinária (kó $\lambda \lambda ı$ $\sigma o v, 11.2$ );

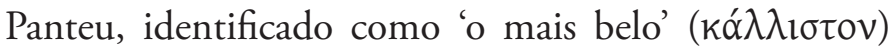
dos jovens por quem se enamorara o rei Cleómenes (Cleom. 37. 14); Antífates, um meirakion 'dos diversos

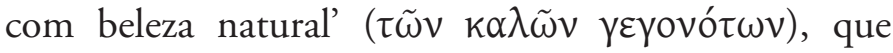
inicialmente despreza o pretendente Temístocles (Them. 18. 2); a fraqueza de Gaio Lúsio, sobrinho de Mário, por 'jovens belos' ( $\mu \varepsilon ı \rho \alpha \kappa i ́ \omega v ~ \kappa \alpha \lambda \tilde{\omega} v$, Mar. 14. 4); o filho mais novo do cônsul M. Fúlvio Flaco, um

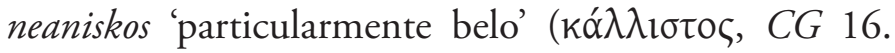
1). Ainda dentro desta linha discursiva de referência neutra a aspectos físicos dos indivíduos é de considerar

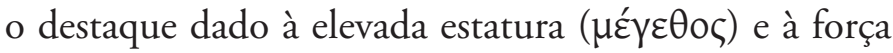
( $\rho \omega ́ \mu \eta)$ do jovem Remo (Rom. 7. 5).

Passemos, de seguida, a analisar os passos em que a beleza e/ou a boa constituição física despoletam acontecimentos ou são o resultado directo deles. Em sociedades em que os relacionamentos homoeróticos, em geral, e a pederastia, em particular, eram práticas aceites $^{3}$, a atracção física decorrente dos atributos

${ }^{3}$ Muito se tem discutido sobre a posição moral de Plutarco face à homossexualidade. As suas críticas são nítidas ou um pouco veladas, quando se trata de abusos sexuais (como veremos no seguimento deste estudo, a propósito das tentativas fracassadas, narradas em Marc. 2. 3, e de Demetr. 24. 5 e Cim. 1. 2). No entanto, o caso dos Espartanos surge como paradigmático para a sua aceitaçấo, quando as relaçóes assentam num profundo respeito

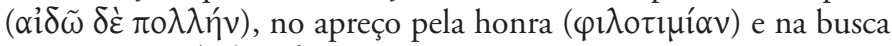

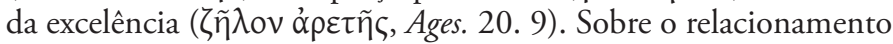
sexual entre jovens, e adultos e jovens, vd. Golden (1990) 57-62. A este assunto voltaremos mais adiante, na rubrica "locais de 
exteriores do indivíduo exerce-se tanto sobre homens como mulheres. Uma série de episódios apresenta o seguinte denominador comum: a beleza e boa figura da criança ou jovem origina a paixão de um adulto ${ }^{4}$. Em termos de consequências sobre as vidas dos envolvidos, os resultados diferem: a disputa pelo amor do mesmo amante (o belo Estesilau), entre Temístocles e Aristides, é responsável por uma rivalidade juvenil que se há-de transpor para a vida política dos dois estadistas atenienses (Them. 3. 2; Arist. 2. 2-4); a condenação do pretendente, Capitolino, pelo senado, acusado pelo pai do menino assediado, Marcelo (Marc. 2. 3); o suicídio

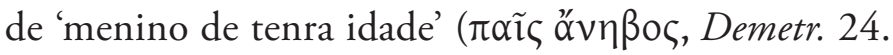
3), quando surpreendido sozinho por um pretendente cujas investidas sistematicamente evita - sacrifício que

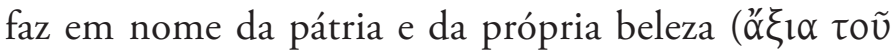

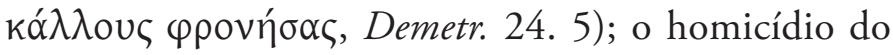
pretendente, que, tal como o anterior, estava disposto a usar da força para conseguir os favores do jovem, possuidor de 'beleza física e nobreza de espírito'

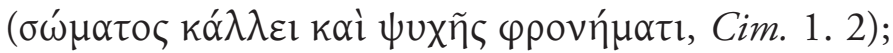
é também por causa da beleza que os jovens cavaleiros

formação", incluída no cap. "Educação".

${ }^{4}$ Sobre a pederastia, características e diferenças entre os códigos comportamentais gregos (baseados no relacionamento entre cidadáos livres) e romanos (em que se admitia o relacionamento do adulto apenas com crianças ou jovens escravos ou náo cidadáos), vd. Lear and Cantarella (2008), D'Ippolito (2007), Hubbard (2006), Skinner (2005: 118-124), Younger (2005: s. v. 'paiderastia' e 'boy-love') e Williams (1999: 63-82). 
de Pompeio perdem a batalha de Farsália contra César, pois, com medo de ficarem deformados com os golpes das lanças que os inimigos lhes arremessam à cara e aos olhos, batem em retirada (Caes. 45. 3-4; Pom. 69. 5-6); a boa figura do jovem Mário desperta compaixão e amor numa das concubinas do rei da Numídia, sentimentos que a levam a ajudá-lo a fugir do cativeiro em que se encontrava (Mar. 40. 11-12); outra forma de libertação conseguida devido, em primeira instância, à grande beleza e estatura elevada do sujeito é a que Nícias concede a um escravo ainda imberbe, cujos atributos físicos lhe mereceram um caloroso aplauso pela sua interpretação do papel do deus Dioniso (Nic. 3. 4).

Se este último passo ilustra o princípio de que os dotes físicos trazem um benefício social evidente ao seu portador, consideremos um caso em que se dá precisamente o contrário. Ou seja, um desempenho militar exemplar, resultando na salvação da sua cidade, acarreta para o neanias lacedemónio Acrótato um nítido favorecimento do seu retrato físico. Segundo conta Plutarco (Pyrrh. 28. 5), ao regressar ao seu posto, coberto de sangue, mas vitorioso, pareceu às mulheres espartanas que se tornara 'mais alto e mais belo' ( $\left.\mu \varepsilon \hat{\imath} \zeta \omega \nu . . . \kappa \alpha \lambda \lambda \hat{i}^{\prime} \omega \nu\right)$.

Porque a beleza os torna apetecíveis, os paides de aparência extraordinária tornam-se um "produto" que se vende ou se oferece como presente a importantes homens adultos (podendo estes considerar o negócio ou a oferta ofensivos, cf. Alex. 22. 1). 
Num contexto em que a beleza colhe particular ênfase, não é de estranhar que o seu oposto, uma aparência feia e ridícula, sirva de contraponto na apresentação de um servo de Alexandre, que, por contraste com tal falta de graça, é um cantor exímio (Alex. 35. 6). Também a fraqueza e debilidade físicas podem determinar, como sucedeu com Demóstenes, o impedimento de um pais receber a preparação física adequada à sua idade (Dem. 4. 4). As alcunhas recebidas na infância podem igualmente reflectir essas mesmas duas realidades contrastantes. A 'boa constituição física'

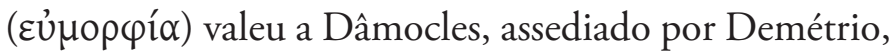

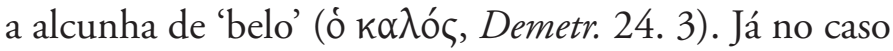
de Demóstenes, fora a aparência física frágil e adoentada que fizera com que as outras crianças lhe colocassem a alcunha de "Bátalo" (Dem. 4. 5) . Mais, o costume de pôr alcunhas vem apresentado como um acto típico dos jovens ( $\mu \varepsilon \imath \rho \alpha \kappa \iota \omega ́ \delta \eta \ldots \pi \rho \circ \sigma \omega v v \mu i ́ \alpha v$, Per. 39. 2), i. e., não próprio de adultos (que, à partida, ao que supomos, atingiram a plena racionalidade e educação).

Poder-se-ia concluir que uma boa aparência física é um dom que se recebe (ou não) da natureza. Daí as já referidas importância da dieta materna durante a gravidez e a motivação dos Espartanos para eliminar os bebés portadores de deformidades. No entanto

5 Plutarco apresenta várias interpretaçôes para o sentido da alcunha, sendo que todas ridicularizam o seu aspecto físico: nome de flautista efeminado; nome de poeta de versos brejeiros; nome usado na região da Ática para denominar os genitais (Dem. 4. 6-7). 
essa seria uma conclusão precipitada, pois Plutarco dá conta da crença dos efeitos da formação sobre o corpo. Para Alexandre (Alex. 71. 1) a educação que mandara ministrar aos paides persas (tanto os treinos como o estudo) produziram efeitos físicos visíveis: corpos viris e belas figuras. Ainda a propósito da importância da dieta e sua adequação à faixa etária e à profissão do indivíduo, não podemos esquecer que é dado como próprio dos jovens e dos soldados (ambos numa fase em que o corpo gasta muitas calorias e, por isso, exige maiores quantidades de nutrientes) não serem capazes de seguir um regime rigoroso (Alex. 72. 2). Situação que, no caso de um doente, acaba por lhe custar a própria vida, pois, mal o médico se afasta, devora um galo cozido e bebe vinho fresco em abundância. Essa seria uma alimentação rica e adequada, ao que se depreende, caso tivesse saúde!

Se a virilidade do corpo masculino se trabalha, tal significa que, do ponto de vista físico, (alguns) jovens podem não possuí-la, e assim o mesmo é dizer que se assemelham a 'donzelas' ( $\pi \alpha \rho \theta \varepsilon ́ v o l) . O u$ seja, têm uma aparência feminina $(\theta \eta \lambda \nu \varphi \alpha v \varepsilon \tilde{i} \varsigma)$, como sucede com dois companheiros de Teseu (Thes. 23. 2 ), imagem que pode ser facilitada por características naturais ou artificialmente conseguidas. Um aspecto fresco (veapoúc, ibidem) e o facto de serem imberbes (caso de Clódio - cf. Caes. 10. 1 e Cic. 28. 2 - e dos jovens Atenienses industriados por Sólon - cf. Sol. 8. 5) são traços naturais que facilitam o travesti ou, como diz o texto grego, o 'assemelhar-se a donzelas' ( $\pi \alpha \rho \theta \varepsilon ́ v o r \varsigma$

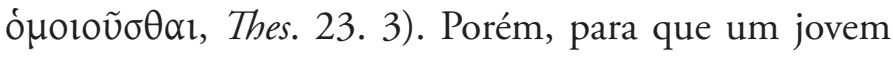


assuma a imagem convincente de uma donzela, há outros ajustes que é necessário fazer ao nível do retrato físico. A descrição pormenorizada que dessa operação de cosmética oferece Plutarco na Vida de Teseu fornecenos, de forma indirecta, dados importantes sobre a imagem física da parthenos e a maneira de obtê-la.

Para se parecerem com donzelas, os jovens têm de apresentar a tez clara (conforme se deduz da prática de mantê-los resguardados do sol e de lhes dar banhos quentes), a pele macia e os cabelos bem tratados (recorrendo, para tal, à aplicação de unguentos) e necessitam de adoptar um tom de voz, roupas e modo de andar femininos (Thes. 23. 3). Os retoques podem, como se lê na Vida de Sólon (cap. 8. 5), passar pelo uso de tiaras e sandálias. Que a voz é dos pontos-chave da identidade feminina, conclui-se do facto de o disfarce de Clódio como flautista perder efeito quando o ouvem falar (Caes. 10. 3; Cic. 28. 3). 
Retrato Psicológico 


\section{Retrato Psicológico}

Antes de passarmos em revista os traços psicológicos mais marcantes das crianças e jovens, há que notar que, tal como hoje, circulavam duas opiniôes, contraditórias, sobre a relação entre o corpo (soma) e o espírito (psyche). $\mathrm{Ou}$ o retrato físico reflecte as características da mente ou difere completamente delas. A primeira tese apresenta-a Plutarco nos seguintes passos: os corpos dos infantes, Rómulo e Remo, que a natureza fez grandes e belos, revelam que as crianças se hão-de transformar em indivíduos corajosos e viris (Rom. 6. 3); quando Plutarco escreve que é 'olhando para o rosto (prosopon)' de Remo que Numitor detecta 'a confiança e ousadia de um espírito (psyche) indómito e impassível diante dos perigos' ${ }^{1}$ (Rom. 7. 5), dá voz à ideia de que o rosto é o espelho da alma; para além da face, também a voz e a actuação (mesmo que se trate de brincadeiras de crianças) são formas de exteriorizar o carácter do indivíduo (Cat. Mi. 1. 3). A opiniáo inversa, de que a aparência nada tem a ver com a maneira de ser, deduzimo-la de Thes. 23. 2, pois os supra referidos neaniskoi de 'aparência feminina' têm 'mentes

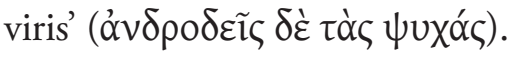

Passemos agora em revista o elenco das principais características psicológicas associadas a quem ainda não

${ }^{1}$ Trad. de D. Leão (cf. Leão-Fialho 2008: 123). 
atingiu a idade adulta. A primeira observação a fazer, como seria de esperar, é a existência de grande variedade, por vezes contrastante, de retratos psicológicos. Comecemos, precisamente, por dar conta dessa consciência de caracteres opostos. Comparando as vidas de Címon e Luculo, o biógrafo conclui que a 'juventude' (neotes) daquele se qualifica de 'censurável e licenciosa"

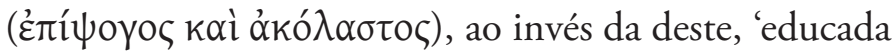

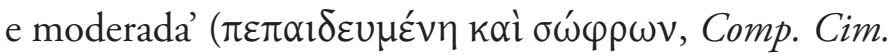
et Luc, 1. 4). Vejamos os comportamentos reveladores dos traços mais marcantes dessas realidades contrárias. Antes, porém, importa notar que, enquanto as más condutas são criticadas, as boas são louvadas. Como se lê em Lyc. 14. 5, do sexo oposto, das parthenoi, partem tanto os 'elogios' (enkomia) cantados aos neaniskoi que possuem 'qualidades viris' (andragathia) como 'insultos' (skommata) para aqueles que delas estão desprovidos.

Por se tratar de uma característica vulgarmente associada aos jovens, a propensão para a licenciosidade é explorada por adultos interessados em captar o seu apoio. Catilina corrompe a juventude romana,

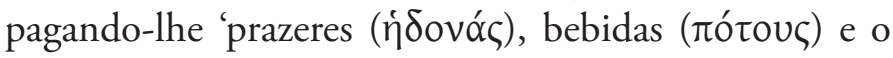

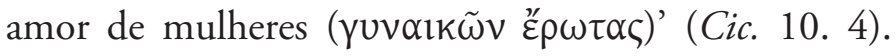
Particularmente permeáveis à influência dos mais velhos, os jovens podem enveredar pelos caminhos da má vida (i. e. das hedonai e dos potoi) por causa dos ensinamentos que recebem de mestres inapropriados (razão que teria levado Cícero a afastar o professor de retórica Górgias da companhia do seu filho, Cic. 24. 8). Também o jovem Marco António revela a mesma permissividade à 
influência das companhias. Cúrio 'iniciou-o na bebida, nas mulheres e em gastos exorbitantes e despropositados'

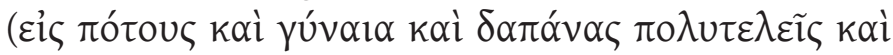

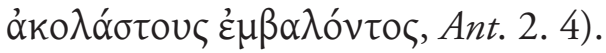

Destes exemplos ressalta outra característica psicológica própria de quem está em crescimento, uma susceptibilidade superior à dos adultos no que à influência de terceiros diz respeito. $\mathrm{O}$ homicida de Filipe da Macedónia, pai de Alexandre, corresponderia a esse tipo do jovem influenciável, pois teria agido instigado pela mãe do herdeiro, Olímpia (Alex. 10. 6). Porque se encontram numa fase de aprendizagem e formação do carácter, os jovens são mais maleáveis ou, como se lê em Cat. Mi. 1. 9, deixam-se persuadir mais facilmente do que os anciấos. Contudo, a situação inversa também é verdadeira: a de um pai ou mentor mais velho que sucumbe à influência que exerce um jovem filho ou protegido, a quem os laços de afecto propiciam esse controlo do (à partida) maior discernimento do adulto. Basta lembrar que Augusto persuade o velho Cícero a conseguir o consulado para ele e para si (que, com apenas 20 anos, ainda não tinha idade para tal, Brut. 27. 3).

Retomemos o tema do hedonismo dos jovens. Quando pretende enganar os espióes de Nícocles, tirano de Sícion, Arato, exilado em Argos e líder de um golpe para depor o déspota da sua cidade natal, encena um dia típico de um jovem endinheirado (Arat. 6. 4). Depois de passar algum tempo a conversar na ágora com os amigos e de se exercitar no ginásio e na palestra, faz 
de conta que se entrega 'aos prazeres e às bebidas' (

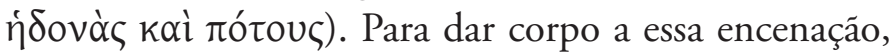
o meirakion recolhe-se a casa com alguns jovens, os servos compram grinaldas de flores e archotes e parecem contratar tocadoras de cítara e flauta, responsáveis pela animação musical do pretenso banquete. Desta forma os espiôes ficam convencidos de que o jovem Arato era inofensivo, pois entregava-se às ocupaçóes próprias dos indivíduos da sua idade. Também os aduladores do tirano da Sicília, Dionísio, rodeavam o jovem de entretenimentos habituais para a sua idade, bebidas, mulheres e aquilo que genericamente o Autor designa

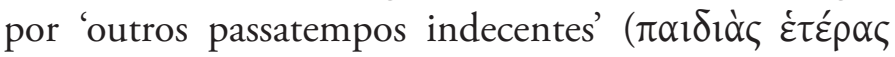

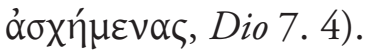

A confirmação de que a 'sedução pelo prazer' que Plutarco chega a designar através do substantivo composto philedonia - é uma característica aceite nos jovens, mas não nos anciãos, percebemo-la da observação feita a propósito do general romano Sula, de quem se diz que, nem mesmo depois de velho, abandonou 'a sua inclinação para o amor e entrega à

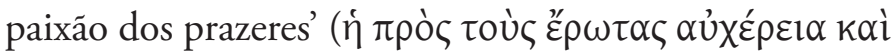

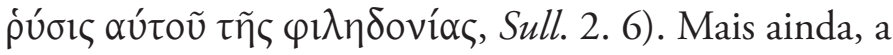

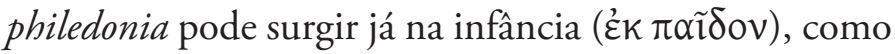
sucedeu com o imperador Otão (Galb. 19. 1). A ingestão de vinho, ontem como hoje, pode tornar-se, por vezes, um vício. Ser philopotes ('amante das bebidas') e ataktos ('indisciplinado') são dois defeitos apontados ao filho de Fócion (Phoc. 20. 1). Também Címon (Cim. 4. 4) é caracterizado de forma idêntica, apenas com a variante 
de ser apelidado de polypotes ('o que bebe muito', i. e. 'beberrão'). O esclarecimento de que, neste último aspecto, se 'assemelha à natureza do avô' indica a crença dos antigos na herança comportamental genética. Em determinadas circunstâncias, Plutarco sugere que a ingestão de akratos, o vinho estreme (contrariando o hábito grego e romano de misturar-lhe água), torna os

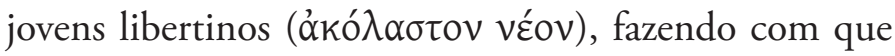
as suas brincadeiras descambem em actos de violência (Alc. 18. 8).

Aliás, ao que se deduz, por exemplo, do apreço geral que as lutas de galos colhiam entre os jovens ( $L y c$. 20. 14), bem como, noutra esfera, do seu entusiasmo pela guerra, um temperamento aguerrido é próprio dos mais novos. Os jovens distinguem-se dos velhos por serem polemopoioi ('fazedores de guerra'), ao passo que estes são eirenopoioi ('fazedores da paz') (Nic. 11. 3). Mesmo na infância o recurso à violência física serve para exteriorizar a raiva, como vemos na atitude de Cássio,

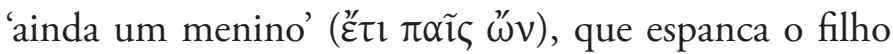
de Sula, por este louvar o poder absoluto do pai (Brut. 9. 1-2).

Dependendo do carácter do indivíduo ou do progressivo amadurecimento trazido pelo passar dos anos, há formas não violentas de manifestar a raiva. Veja-se o caso de Catão de Útica (cap. 7), que, qual o poeta grego Arquíloco, encontra na poesia iâmbica um

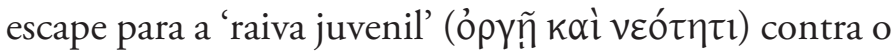
rival que lhe roubara a noiva. Porém, de um modo geral, as crianças, e até mesmo os jovens, apresentam uma 
carência de coragem que as distingue dos adultos. Duas demonstraçóes típicas dessa "moral incompetence" (Golden 1990: 5) são o medo que os bebés têm do escuro ou de ficar sozinhos (Lyc. 16. 4) e os tremores que os jovens têm quando passam por algum ritual de iniciação (Cic. 22. 2). Menos honroso, mas digno de menção neste ponto, é o medo que os jovens soldados podem demonstrar em campo. $\mathrm{Na}$ argumentação que usa para rebater o apelo de um jovem imponderado e pretensioso, Leóstenes, a que os Atenienses se envolvam na chamada Guerra Lamíaca ${ }^{2}$ (Pyrrh. 1), Fócion adianta, entre outras coisas, que esse dia só deve chegar quando passar 'a ver que os jovens não demonstram vontade de abandonar o seu posto' (Phoc. 23. 3). Dessa cobardia acusará o octogenário Fócion e estratego da expedição contra a Beócia um meirakion que, abandonando o seu posto sem autorização, avança cheio de vã glória contra o inimigo, para de imediato recuar. Particularmente em contexto de guerra, a 'indisciplina' (ataxia, à letra: 'abandono do seu posto') e a 'fraqueza' (malakia), grupos semânticos em que entra, sem dúvida, a cobardia, são considerados crimes à luz das leis grega romana. Atesta-o nas Vidas o facto de uma das causas brilhantes de Cícero, enquanto questor, ter consistido precisamente em absolver um punhado de jovens de

2 Após a morte de Alexandre, em 323 a. C., Atenienses, Tessálios e Beócios formam uma aliança de insurreição contra os Macedónios. Ainda conseguem derrotar Antípatro, que se refugia em Lâmias, mas acabam por ser vencidos, com a tomada do porto do Pireu a simbolizar o fim da liberdade grega. 
ilustres famílias romanas, acusados de semelhante delito perante o pretor da Sicília (Cic. 6. 2).

Reverso da cobardia, a coragem também surge como um traço de carácter de crianças e jovens, revelada em contexto de guerra ou revolucionário. Comecemos pelos de mais tenra idade, as 'crianças pequenas' ( $\tau \grave{\alpha}$

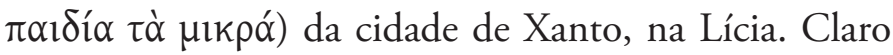
que a própria faixa etária em que se inserem sugere que, em grande parte, a decisão dos seus actos cabia aos progenitores. Mas, a forma como Plutarco descreve a sua participação no suicídio colectivo dos habitantes cercados por Bruto revela autonomia das crianças, isto é, iniciativa própria (Brut. 31. 4). É na forma do particípio do verbo 'ordenar, exortar' ( $\varepsilon \varepsilon \lambda \varepsilon u ́ \omega)$ que notamos a participação activa dos menores num acto tão violento, mas que, à luz da moral dos seus autores, representa a coragem de morrer livre, face ao que seria a cobardia de serem feitos escravos, assim que a cidade fosse tomada. Plutarco conta que, para além dos homens adultos e das mulheres, também as 'criancinhas' encontraram a morte das seguintes formas: saltando para o fogo, precipitando-se de cabeça do alto das muralhas da cidade e, por fim (esta é a que nos esclarece, sem margem para dúvidas, do voluntarismo com que corajosamente acompanham os pais na morte), com os pescoços desnudos e colocados sob as espadas dos pais, lhes 'ordenavam' ( $\kappa \varepsilon \lambda \varepsilon v ́ o v \tau \alpha)$ que desferissem o golpe fatal. Apesar de não podermos descurar que todo este ambiente corresponde a um fenómeno próximo do que se conhece por histeria colectiva (note-se a alusão no 
texto ao alarido e gritaria que envolve o momento do

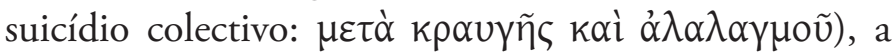
verdade é que, perante a eminência da captura, vários foram os grupos que optaram por matar-se a entregar-se, não poupando ninguém, nem mesmo os mais novos. Contra os Gauleses, César tem que lutar arduamente para capturá-los. Não são as muralhas das cidades que protegem o inimigo e servem de obstáculo à captura, mas sim os carros, com que formam uma fortaleza (Caes. 18. 4). Para a defender, o bárbaro conta também com a colaboração das mulheres e dos 'filhos' (paides).

Passemos agora à categoria dos pré-adultos, os neoi. De natureza impulsiva e dotados de força e astúcia, alguns distinguem-se pela audácia das sua iniciativas. Nesta capítulo temos de incluir o tebano Pelópidas. Apesar de ser um dos mais jovens exilados em Atenas, por se opor ao regime tirânico que imperava na sua cidade, cabe-lhe a iniciativa de urdir um plano para derrubar o governo da pátria (Pel. 7. 1-2). Do golpe traçado, faz parte a decisão de que seja um grupo dos mais novos (ỏ $\lambda$ íyous $\delta \dot{\varepsilon} \tau \tilde{\omega} v$

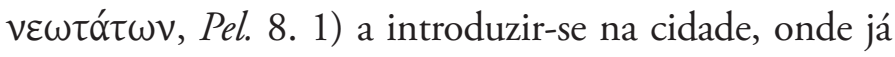
contam com apoios. Os rebeldes seguem disfarçados de caçadores, para poderem passar despercebidos e reduzir os riscos de fracasso. A alusão ao disfarce, quer aqui, quer como anteriormente referido a propósito do travesti, revela uma característica mais comum e própria dos jovens do que dos homens maduros, a maleabilidade para se adaptarem a situaçóes novas.

Quando são bem sucedidos estes actos de valentia, a cidade não é parca no reconhecimento prestado aos 
seus heróis. Para além de coroas e da recepção em cortejo por figuras distintas da cidade (como os sacerdotes, Pel. 12. 6), outras formas, não muito diferentes no essencial, de reconhecimento público da coragem e sucesso de um jovem vêm relatadas pelo nosso biógrafo. Consideremos apenas que ele escreve que, 'apesar de ser ainda jovem' (őv Marcelo combateu, sem nunca fugir a um único desafio (note-se a censura velada aos cobardes!), valeulhe o reconhecimento militar (com os comandantes a oferecerem-lhe coroas e prémios) e o civil e religioso (ganhando os lugares de edil curul e áugure).

Retomemos a 'sedução [dos jovens] pelos prazeres' (philedonia). Como seria de esperar, nem todos os jovens, porém, levam uma vida pautada pela satisfação dos prazeres sensoriais. Excepção a essa tendência geral para buscar as hedonai encontramo-la tanto num exemplo singular como colectivo. Veja-se o caso do rei espartano reformista Ágis, de quem se diz que, mal subiu ao trono, com menos de 20 anos, renunciou de imediato aos prazeres (Agis 4. 2). Atraídos pelo poder oratório do académico Carnéades, os jovens romanos intelectuais abandonam os seus 'outros prazeres e

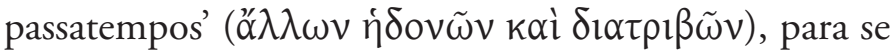
dedicarem à filosofia (Cat. Ma. 22. 3).

Outras duas características fundadas no conceito contido na raiz phil- ('gostar de') vêm claramente associadas aos jovens: a philoneikia ('paixão da vitória') e a philotimia ('paixão das honrarias', podendo também adquirir os sentidos decorrentes de 'ambição, 
rivalidade'). Em Num. 8. 21, Plutarco afirma que a

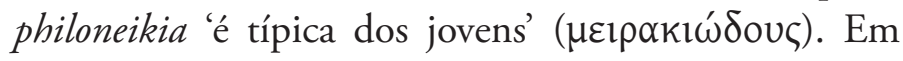
Pom. 29. 5, considera-se que Aquiles não se comportou

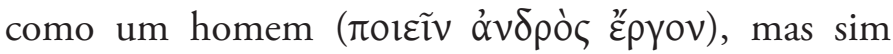
como um garoto ( $\alpha \lambda \lambda \hat{\alpha} \mu \varepsilon l \rho \alpha k i ́ o v)$, quando impediu os restantes Gregos de alvejarem Heitor, pois queria para si essa fama. Também o general romano, aqui comparado a Aquiles, norteia a sua estratégia militar movido pela inveja (phthonos) e rivalidade (philotimia) em relaçáo a Metelo.

Ter uma natureza que se caracterize pela 'paixão de aprender' (philomathia) e pela 'paixão do saber' (philosophos) não calha em sorte a todos os indivíduos. No entanto, em todos os tempos houve o que hoje se costuma chamar "crianças sobredotadas". Sobressaindo de forma indiscutível do círculo de colegas de escola pela inteligência e acuidade demonstradas em todas as matérias, podem tornar-se o centro das atençóes de companheiros e respectivos familiares, ou, o que também não é raro, despertar o despeito de pais mais incultos. Cícero foi uma dessas crianças, tanto que, ainda na infância, escreveu um poema (Cic. 2. 3). Criança e jovem favorecido pelo meio intelectual de alto nível que o rodeia, Alexandre exemplifica duas qualidades que, no entanto, lhe vêm atribuídas como inatas (i. e., que possui devido à sua physis): a 'paixão de estudar' (própria do philologos, ou 'erudito') e a 'paixão da leitura' (característica do philanagnostes) (Alex. 8. 2).

Passemos agora ao domínio dos afectos. Retomando o campo semântico de phil-, constatamos 
a sua aplicação ao pai, mãe e irmão do indivíduo (destinatários preferenciais do afecto de crianças, jovens e até mesmo adultos). Mostrar um apreço especial pelo pai é ser philopator (Demetr. 3. 1), pela mãe philometor (Sol. 27. 7; Sert. 2. 1) e pelo irmão philadelphos (Sol. 27. 7; Cat. Mi.3). Ao que nos parecem sugerir as histórias de Sertório e de Catáo de Útica, a perda de um ou dos dois progenitores durante a primeira infância leva a compensar essa carência emocional com o intensificar dos laços entre a criança e um outro familiar próximo. No domínio dos afectos, as crianças não restringem, no entanto, as suas manifestações às pessoas. Particular atenção merecem os animais de estimação (Bradley 1998), conforme atesta o pranto da filhinha de Emílio Paulo, motivado pela morte do cão Perseu (Aem. 10. 7-8).

Claramente identificada como traço típico da psicologia infantil é a 'vontade de agradar'. A atitude dos cortesãos do jovem tirano de Siracusa, Dionísio, de lhe darem conselhos que agradem ao monarca e não que zelem pelos seus interesses, é considerada pelo sensato tio do governante 'uma forma de pensar

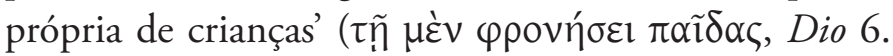
4). Desta comparação de adultos com crianças, percebese que se reconhecia que estas últimas eram "mentally incapable" (Golden 1990: 5). Daí que uma forma de insultar os adversários seja chamar-lhes 'criancinhas' ou, em português coloquial, 'putos' (paidarioi), como faz César aos jovens (neoi) filhos de Pompeio, que se batem valentemente contra o seu exército (Caes. 56. 3). Essa inferioridade intelectual ressalta ainda da 
associação das crianças a outras figuras vulgarmente tidas por portadoras de alguma limitação intelectual: mulheres, doentes, loucos, entre outros (Golden 1990: 7; Harlow and Laurence 2002: 34). Pois bem, como se lê em Dio 2. 4, a mente das 'crianças de tenra idade' (paidaria), segundo uma opiniáo corrente, é comparada à de 'mulheres' ( үúvala) e de 'pessoas perturbadas'

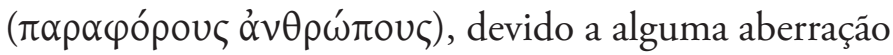
do espírito ou deficiência física. Essas fragilidades psíquicas e/ou físicas é que criariam as condiçóes para verem fantasmas e terem apariçóes.

A inocência, outro atributo próprio das crianças, merece particular respeito por parte de um romano apresentado como modelo de pai, Catão Censor, justamente apelidado de 'bom pai' (pater agathos, Cat. Ma. 20. 1). Evitar palavras indecentes e privar-se de tomar banho com o filho são formas de zelar pela preservação de um estado de alma que aproxima os mais novos do divino (Golden 1990: 10). A sugestão desse estatuto sagrado vem duas vezes inequivocamente referido no capítulo em apreço da Vida de Catão Censor. Primeiro, quando Plutarco escreve que Catão considera a mulher e o filho 'o

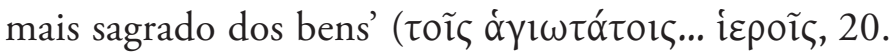
3). Mais adiante, quando, a propósito da decência das palavras que pronuncia na presença da criança, compara esta às virgens sagradas, as Vestais. Outra forma de se manifestar a afinidade das crianças com os deuses é reconhecer-lhes capacidades divinatórias. Assim sucedeu com o general Emílio Paulo, quando 
interpretou a morte do cão de estimação da filha um bom presságio (Aem. 10. 8), uma vez que este tinha o nome do seu inimigo, o rei Perseu ${ }^{3}$.

Também os jovens pensam de maneira diferente dos adultos, realidade que se constata quando Plutarco junta ao verbo $\pi \rho \circ \sigma \delta o k \alpha ́ \omega$ ('julgar’) a forma adverbial $v \varepsilon \omega \tau \varepsilon \rho 1 k \tilde{\omega} \zeta$ ('à maneira dos jovens'). Sendo jovem e por 'pensar como um jovem' ( $v \varepsilon \omega \tau \varepsilon \rho \iota k \tilde{\omega} \varsigma \pi \rho \circ \sigma \delta o k n ́ \sigma \alpha \varsigma)$ é que Díon acalenta a vã esperança de que, como sucedera consigo, os ensinamentos de Platão para atingir a virtude surtam efeito sobre o tirano de Siracusa, Dionísio (Dio 4. 7).

Ou seja, a imaturidade leva os indivíduos a avaliar mal as situaçóes. Porém, ao tornarem-se maduros, são capazes de reconhecer os erros que cometeram, atribuindo-lhes como causa uma outra característica própria de quem ainda está no início da vida: ser

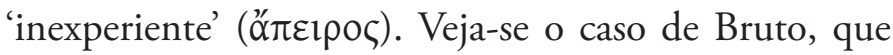
admite ter sido essa a razáo para, na juventude, ter criticado Catão por cometer suicídio (Brut. 40. 7). Uma das esferas em que a falta de experiência é apresentada como um risco sério para a vida ou reputação de um jovem é a militar. Sabendo nós que o serviço militar tinha início por volta dos 17 anos (Cat. Ma. 1. 8; cf. Eyben 1981: 345), os primeiros anos destinavam-se já a fazer todo o aprendizado das lides guerreiras.

${ }^{3}$ Como observa Johnston (2001) 108, reza um antigo provérbio grego que "o vinho e as crianças falam a verdade". Sobre o apego das crianças a animais, vd. Harlow and Laurence (2002) 49. 
Plutarco dá vários exemplos de generais a quem os soldados, conforme lemos nos seus textos,

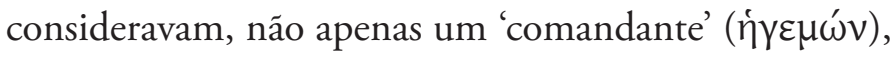
mas também um 'mestre benevolente em matéria

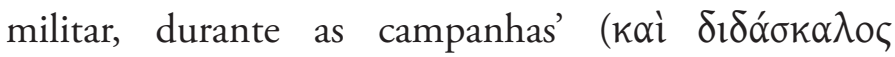

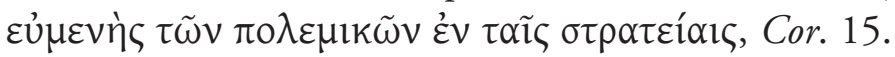
7). Ensinava-lhes os valores da virtude e da modéstia (ou seja, a não ter inveja dos êxitos dos outros nem a gabar-se dos seus). Emílio Paulo é outro general com esse pendor didáctico bem evidenciado (Aem. 17. 4, 27. 1). Reconhecido ao campo de batalha o estatuto de escola de formação militar, não é de admirar que sejam inúmeras as referências à participação dos protagonistas das Vitae, na sua juventude, em campanhas chefiadas por generais famosos (de que destacamos: Coriolano, ao lado de Tarquínio: Cor. 3; Catão Censor, aos 25 anos, sob o comando de Fábio Máximo: Cat. Ma. 2. 3; o filho de Catão ao lado de Emílio Paulo: Cat. Ma. 20. 10; Pirro ao de Demétrio: Pyrrh. 4. 4; Pompeio ao lado do pai: Pom. 3. 1; Cícero sob Sulla: Cic. 3. 2).

Dos dois filhos que levou consigo para a guerra, Emílio Paulo não só reconhece que sentia mais afecto pelo mais jovem, o futuro Cipiâo Emiliano, que haveria de destruir Cartago e Numância (a preferência por um dos membros da prole pode ser considerada mais uma característica intemporal no género humano), como atribui uma causa exacta para a sua pretensa morte em combate: a inexperiência (úđ’ ỏđzııías, Aem. 22. 4), responsável por se deixar capturar pelo inimigo (na verdade, ele há-de aparecer vivo, coberto de sangue e 
rejubilando de prazer pela sua primeira vitória: Aem. 22. 8). Do lado grego é um outro 'jovem inexperiente'

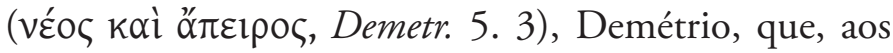
22 anos, sofre uma pesada derrota, em Gaza, diante de Ptolomeu. No capítulo seguinte desta mesma Vida (Demetr. 6. 1), a resposta que o pai de Demétrio, Antígono, teria enviado ao adversário que vencera o filho deixa bem clara a ideia de que o prestígio de uma vitória também se avalia pela idade dos vencidos. $\mathrm{O}$ que lhe manda dizer é que vencera 'rapazes imberbes' (åyeveíouৎ), mas que o próximo combate seria travado contra 'varōes' (ớv $\delta \rho \alpha \varsigma)$. O tom depreciativo é óbvio!

Audaz, mas jovem, Arato passa por grandes dificuldades para obter apoios que o ajudem a derrubar o tirano de Sícion, exactamente devido à sua inexperiência

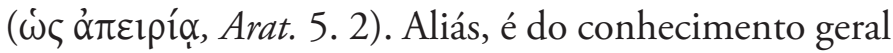
que se tratava de algo 'despropositado' (átotov) dar conselhos a um líder (neste caso o imperador Galba)

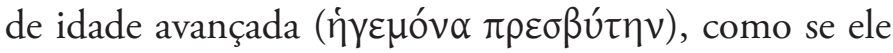
fosse um meirakion (Galb. 13. 4).

Mas, como temos vindo a sublinhar, a insistência constante do discurso de Plutarco assenta na crença de que os jovens estão em formação. Ou seja, a experiência adquire-se. Assim se deu com o jovem Fócion, ajudado a atingir a 'experiência militar' ( $\pi \circ \lambda \varepsilon \mu \imath \kappa \tilde{\omega} v$, Phoc. 6. 1). Foi um aluno tão virtuoso (ao que somos levados a supor) que lhe coube corrigir a natureza do mestre, quando esta era caprichosa e violenta. Em suma, centrando-nos na atitude de Cábrias, concluímos uma outra verdade intemporal 
sobre o homem e a sua idade: não são só os mais velhos que detêm a sensatez e nem todos os jovens fracassam à primeira. Da mesma sorte (de possuir um discípulo assim dedicado e educado) náo havia de gozar o próprio Fócion. Por morte do seu amigo Cábrias, coube-lhe ser tutor do órfão Ctesipo, cuja principal característica, insuportável, é a presunção (numa expedição, importuna o tutor e comandante com as suas tentativas de corrigilo ou partilhar com ele a chefia da guerra, Phoc. 7. 3-4).

Só mais uma evidência de que os jovens, ao contrário de Ctesipo e à imagem de Pompeio (cf. infra, Pom. 8. 5), podem ter consciência de algumas hierarquias naturais decorrentes da idade, ainda em termos militares. Bruto revela-se ciente de que o ser jovem e ser nomeado para substituir um general mais velho numa missão pode não só ofender este último como deixar o próprio incomodado com a situação (Brut. 3. 3). No entanto, não desobedece às ordens do tio, Catão de Útica, assumindo ele a responsabilidade de fazer chegar a Roma, intacto, o tesouro de Ptolomeu.

Há quem possua (ou se lhe atribua, pela fama e estatuto que veio a alcançar!) capacidades naturais ou adquiridas para, desde muito cedo, se revelar em campo um general de sucesso. Observemos, de seguida, o elenco dos mais distintos jovens génios militares. $\mathrm{O}$ voluntarismo, forma encoberta de demonstrar que um indivíduo se acha competente para determinada missão, revela-o o filho mais velho de Emílio Paulo, Fábio Máximo, ao oferecer-se para comandar uma das hostes de homens na guerra contra o rei Perseu da Macedónia, 
apesar de não passar ainda de um meirakion (Aem. 15. 4). Pompeio, jovem de 23 anos, audaz e determinado, decide desrespeitar o protocolo militar corrente, isto é, esperar que alguém o nomeasse 'general' (strategos, Pom. 6. 5). Toma a iniciativa de actuar como comandante de um exército, formado por três legióes, prerrogativa que lhe permite proclamar éditos e nomear oficiais militares. Semelhante idade náo lhe reduz a expertise guerreira e, após bater três ofensivas de generais do partido de Mário, acaba por ser designado por Plutarco como um

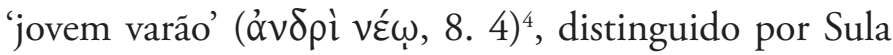
(idem, 8. 3) com o título militar supremo de Imperator (mérito inusitado em quem ainda não atingira o lugar de senador). Apesar de não recusar a honra, Pompeio não é pretensioso a ponto de desconhecer que a sua juventude o destinava mais a lugares de auxiliar de comandantes mais velhos, argumento com que se escusa de substituir Metelo à frente das tropas de Sula

${ }^{4}$ Não esqueçamos que a barreira entre a juventude e a do jovem adulto é ténue e oscilante, conforme precisamente confirma o caso de Pompeio. Apesar de aquele ser, como vimos, designado por Plutarco de aner neos ('jovem adulto'), quando Sula suspeitou que os movimentos independentes de Pompeio, chefiando um exército, poderiam ser um acto de sedição, atribui-lhe a ele e aos seus seguidores, uns potenciais rebeldes, a designação, que pode ser ou não depreciativa, de paides (Pom. 13. 5). Mais depreciativo, e até em parte falso, é César chamar aos 'filhos' ( $\pi \alpha \tilde{i} \delta \alpha \varsigma)$ de Pompeio

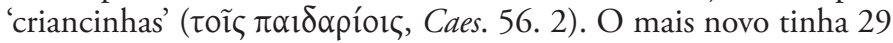
anos e o mais velho um pouco mais (Stadter 1999: 516, n. 346).

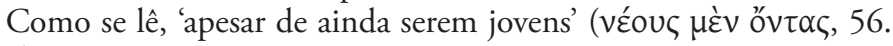
$1)$, conseguiram reunir um vasto exército e mereceram a posição de comandantes devido à valentia ( 
na Gália, mas oferece-se para ser seu assistente (Pom. 8. 5). Poderemos considerar a sensatez do general nesta matéria apenas aparente? De facto esta é uma pergunta pertinente, se tivermos em conta que o mesmo Pompeio tem a ousadia de pedir a Sula que o deixe entrar em triunfo em Roma (Pom. 14. 1), distinção concedida por lei apenas a um membro do senado ${ }^{5}$ e que não fora atribuída nem mesmo a Cipiáo, depois de vencer os Cartagineses. E as referências à juventude de Pompeio e despropósito daí decorrente para as suas pretensões são óbvias: a barba mal começava a despontar-lhe no rosto, logo não tinha idade para ser senador (Pom. 14. 2)!

Entre os Gregos, em particular um espartano, o jovem rei reformista Ágis, distingue-se, entre outros aspectos, por possuir o carisma e o talento para, não passando de um meirakion, um neaniskos e o mais novo dos neoi, comandar, por ordem dos magistrados, um contingente espartano em auxílio do líder da Liga Aqueia, Arato (Agis 14). O reconhecimento de que é ao mais velho e mais graduado chefe de uma expedição que cabe o poder é, nesse momento, o argumento do rei espartano para colocar nas mãos de Arato a decisão sobre como prosseguir as manobras em Corinto (Agis 14. 3). É caso para dizermos: valente, mas humilde!

Para o final deste elenco de jovens comandantes, guardei a figura de Alexandre. Não tanto pela grandeza

${ }^{5}$ A questura, a primeira magistratura após a qual se podia aceder ao Senado, náo se atingia antes dos 31 anos e, em 80 a. C., data dos acontecimentos em questáo, Pompeio tinha apenas 26 anos. 
da sua obra - a ponto de lhe valer a designação Alexandre Magno - mas porque o que de momento nos interessa é a juventude dos líderes e a confirmação dos seus dotes de chefes militares. No caso do herdeiro de Filipe da Macedónia, apesar de contar apenas 16 anos, por ausência do pai em expedição contra Bizâncio, fica ele no lugar de regente (Alex. 9. 1). Ainda na faixa etária do que hoje se designa por adolescente, foi capaz de submergir uma rebelião, bateu-se em Queroneia contra os Gregos e aí diz-se ter sido o primeiro a vergar as linhas de uma força de elite de 300 Tebanos (idem, 9. 2).

A imprudência de actos e palavras é outro traço de carácter associado aos jovens. Aos ouvidos do experiente e vivido Fócion, as palavras de incentivo à guerra que Leóstenes, um meirakion, dirige ao povo de Atenas evidenciam a arrogância e vanglória que caracterizam o seu autor (Phoc. 23. 2). Em Alex. 48.5 deparamos com a afirmação expressa de que as palavras imponderadas são recorrentes, o mesmo é dizer que são um traço típico, dos jovens, em particular quando, sob o efeito do vinho, se vangloriam dos seus feitos bélicos à mulher amada.

Os jovens são, por natureza, impulsivos (i.e., entregam-se aos 'instintos', ó $\rho \mu \alpha i ́)$, constatação que Plutarco regista em Them. 2. 7, precisamente ao caracterizar a fase da vida em apreço, a juventude. Essa tendência natural, responsável por tornar Temístocles

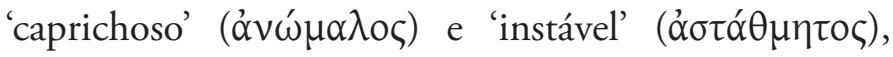
só poderá ser contrariada através da 'razáo' (logos) e da 'educação' (paideia). Outra característica natural,

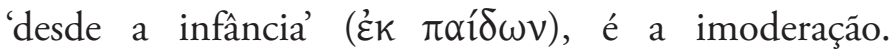


Segundo Plutarco, os legisladores tebanos suavizaram o carácter dos jovens ( sua tendência inata para serem 'irascíveis' ( $\theta u \mu o \varepsilon l \delta \varepsilon ́ c)$

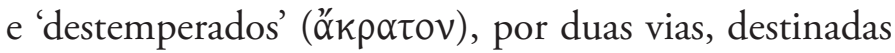
a amolecê-los: ouvir música de flauta e estimular os relacionamentos homoeróticos no principal espaço de convívio dos rapazes, a palestra (Pel. 19. 1).

Se, como vimos no início deste ponto, desde a infância o aspecto revela a alma, podemos perguntarnos se o amadurecimento acarreta ou não alteraçóes na psyche do indivíduo. Consideremos dois exemplos apenas. Uma vez mais, Plutarco dá-nos tanto uma resposta afirmativa como uma negativa. Não, o passar dos anos não modifica a alma do sujeito. Veja-se o caso de Catão de Útica, que, desde menino (Ėk $\pi \propto \iota_{1} \delta$ óou), mostrou possuir um carácter 'inalterável, impassível e

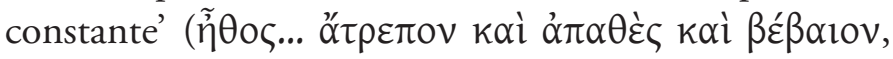
Cat. Mi. 1.3). Sim, os traços psicológicos que se revelam na juventude alteram-se na idade adulta. Alcandro é disso mesmo a prova viva. Foi sob a orientação de Licurgo que 'passou de jovem insubordinado e mal comportado a adulto bem educado e responsável' ('̇k

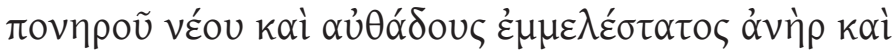

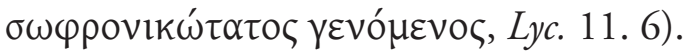


EduCAÇÃo 


\section{EDUCAÇÃo}

Sob esta rubrica consideraremos as informaçóes que as Vidas nos fornecem sobre os conteúdos formativos, os educadores (pais, tutores, amas, pedagogos e professores $)^{1}$ e os locais públicos de formação.

Embora seja um dado adquirido e, de tão banal que é, a dispensar longas reflexóes, a ideia de que a idade própria para formar os indivíduos corresponde aos períodos iniciais da sua vida (a infância e a juventude) merece da nossa parte uma evocação ilustrativa, que retiramos da Vida de Catáo Censor. Deduzimos das palavras de Plutarco que uma criança é como uma matéria prima bruta, pronta a ser 'moldada' ( $\pi \lambda \alpha$ á $\tau \tau o v \tau \imath)$

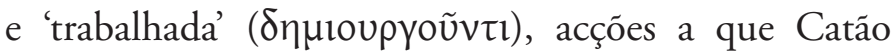
sujeitou o filho, educando-o (cap. 20. 9). Na mesma linha de pensamento, a pouca idade vem, mais adiante (cap. 21. 1), apresentada como condição sine qua non para se ser sujeito ao processo de educaçáo. De facto,

${ }^{1}$ Em Aem. 33. 6, a propósito da descrição do cortejo triunfal em que o general romano exibe o rei conquistado, Perseu, e os seus filhos, Plutarco menciona as habituais figuras responsáveis pela sua educação e cuidados (e que as acompanhavam no desfile): amas (tropheis), professores (didaskaloi) e pedagogos (paidadogoi). Da mesma tríade de 'cuidadores' não foi naturalmente dispensado Alexandre (Alex. 5. 7), se bem que os ensinamentos que the transmitiu Aristóteles não se assemelhavam em nada aos dessas três personagens tradicionais da educação das crianças. 
o Romano comprava escravos 'pequenos' ( $\mu$ ikpoús), isto é, que 'ainda podiam ser criados e educados'

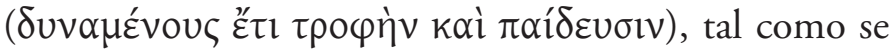
faz aos cachorrinhos e aos potros.

\section{Conteúdos formativos}

Espelho da cultura greco-romana em que se insere, Plutarco testemunha a aliança estreita entre intelecto e corpo, sintetizada por Gregos no ideal da kalokagathia e por Romanos na sentença mens sana in corpore sano ${ }^{2}$. Por um lado, o biógrafo enfatiza a dimensão moral da educação, afirmando que a 'tarefa' de educar é 'nobre' ( $\kappa \alpha \lambda$ òv ع́pyov), pois tem

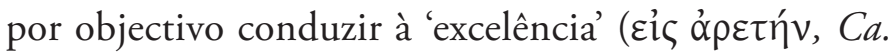
Ma. 20. 9), e afirma ser 'a mais importante e bela

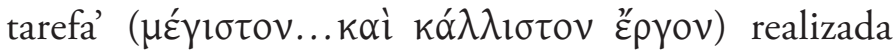
pelo famoso legislador espartano, Licurgo (Lyc. 14. 1). Por outro, não deixa de dar conta dos benefícios proporcionados pelos exercícios físicos, responsáveis, por exemplo, pela boa forma e bela aparência dos três mil rapazes persas educados segundo o modelo helenístico (Alex. 71. 1).

${ }^{2} \mathrm{O}$ termo kalokagathia (substantivo derivado da junção dos adjectivos kalos ka(i) agathos) designa a aliança entre corpo e espírito, i. e., entre o belo (kalos) e o bom (agathos), ideal almejado pela educação grega antiga (anterior à chamada educaçáo nova, impulsionada sobretudo pelos Sofistas, no séc. V a. C.). Emprego-o na sua acepção intemporal, ou seja, como conceito que traduz uma união indissociável entre as componentes intelectual e física. Já a expressão latina consagrou-a Juvenal (Sátira 10.356). 
Sabendo nós que as principais esferas de actuação de um adulto de condição livre eram a vida pública e o exército, que matérias e treinos eram esses a que eram sujeitos os meninos, para se fazerem homens? À excepção do modelo educativo espartano, a chamada agoge (à letra 'acção de conduzir', i. e., 'maneira de viver'), nenhum outro paradigma educativo merece da parte do biógrafo uma análise detalhada. Comecemos, pois, por tomá-lo como primeiro ponto da nossa reflexão sobre a paideia ('educação').

Não é de estranhar a atenção particular dedicada por Plutarco à educaçáo dos Espartanos, na medida em que lhe era reconhecida um estatuto singular no panorama cultural da época. Na verdade, a agoge teve um papel central na definição da identidade espartana, pois, devido ao seu carácter único, funcionou como factor de distinção dos Espartanos, primeiro no universo grego, posteriormente nos vastos impérios helenístico e romano. Ou seja, o que fez dos Espartanos indivíduos singulares no panorama da História da Antiguidade e contribuiu de forma decisiva para a sua fama lendária de soldados invencíveis foi esse seu 'modo de vida' (Kennell 1995: 148). Aliás, a prova de que esse sistema de treino constitui, ao tempo de Plutarco, uma referência no panorama educativo da época reside na atracção por ele exercida em jovens de toda a Grécia, que iam participar nesse "revived training regime" (Stadter in Waterfield and Stadter 1998: 4).

A popularidade do modelo e o orgulho dos Espartanos em que o seu programa formativo era o 
melhor são indirectamente atestados na Vida de Pirro (26. 21). Com o intuito de persuadir os embaixadores de Esparta de que estava do seu lado, o rei dos Molossos mente-lhes. Um dos argumentos usados para obter a aliança com os interlocutores consiste precisamente em fazer-lhes a falsa promessa de que enviaria os seus filhos mais jovens para Esparta, para estes serem educados

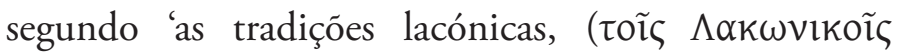
$\varepsilon^{\prime}(\theta \varepsilon \sigma \mathrm{lv})$, por acreditar que essa formação lhes daria vantagem sobre os restantes príncipes. Forma de pensar diversa tem Fócion, que acredita sinceramente nas potencialidades disciplinadoras do exercício físico e, em consciência, toma a decisão de curar o jovem filho (meirakion) do seu vício da bebida e vida desregrada, levando-o para Esparta, para se juntar aos jovens (neaniskoi) formados no sistema da agoge (Phoc. 20. 4).

$\mathrm{Na}$ Vida de Licurgo (16-22), o biógrafo fornece a descrição mais detalhada que até nós chegou do sistema educativo público espartano ${ }^{3}$. Do ponto de vista cronológico, o testemunho de Plutarco contém informaçóes de fases diversas da história da agoge. Enquanto o uso do presente do indicativo deve ser interpretado como indicador de que a prática em questão

${ }^{3}$ Como observa Stadter (in Waterfield and Stadter 1998: 3), "Lycurgus is not so much a biography as the account of a way of life, the Spartan regime and social system (agoge) which was ascribed to Lycurgus and which set Sparta apart from other cities of classical Greece". Para um estudo aprofundado da agoge, remetemos para a leitura de alguns títulos indicados na bibliografia final de Kennell (1995). 
continuava em vigor na época romana, os tempos do passado reportam hábitos que haviam caído em desuso (Kennell 1995: 24-25) ${ }^{4}$. O detalhe e extensão com que apresenta o sistema de treino típico espartano reflecte, quando a mim, o desejo do escritor em oferecer um relato pormenorizado de um assunto que sabia atrair o público, mas cuja memória, devido às origens remotas e extinção de alguns hábitos, era urgente preservar.

$\mathrm{O}$ principal traço distintivo do modelo educativo espartano reside na sua originalidade, i. e., em ser diferente das práticas em uso em todo o universo grego e romano. Esse carácter único ressalta da própria técnica discursiva de caracterização pela negativa, i. e., de "dizer o que não é”. Ou seja, ao descrever o que não é a prática espartana, Plutarco dá a saber o que era o hábito grecoromano. Assim, ao invés do que se passa no resto do mundo greco-romano, não é ao pai que cabe decidir como criar e educar um filho, missão em que contava habitualmente com os serviços de um pedagogo escravo ou assalariado (Lyc. 16. 7). O mesmo é dizer que a

${ }^{4}$ A história da agoge é feita de descontinuidades. A primeira, que vem pôr termo ao período clássico (iniciado ca. VI a. C.), tem lugar no reinado de Cleómenes III (235-222 a. C.). Esta revitalizaçáo do modelo de Licurgo, que dura apenas trinta e nove anos, volta a ser suspensa, em 188 a. C., desta feita pela mão de Filopémen, o chefe da Liga Aqueia, que obriga os Espartanos a trocarem 'a educaçáo

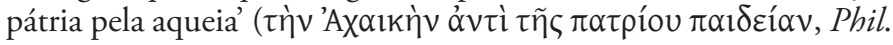
16). Ou seja, durante quarenta e dois anos, os Espartanos vivem sob as leis e o sistema educativo dos Aqueus. A última fase da agoge, a fase romana, tem início em 146 a. C. e estende-se pelo séc. IV A. D. (Kennell 1995: 5-27). 
iniciativa e responsabilidade formativa não competiam à família, mas ao estado. O sistema educativo espartano tem, pois, a originalidade de ser um ensino público, sob o controlo de um oficial, o paidonomos (Lyc. 17. 2), o magistrado responsável pela educação dos rapazes. Quanto aos conteúdos formativos, estes ajustam-se ao objectivo de preparar as crianças para serem cidadãossoldados. Daí que a primazia do investimento formativo resida numa preparação física adequada ao futuro desempenho militar. A componente intelectual não é descurada, embora se veja francamente secundarizada e reduzida ao essencial.

Apesar de a paideia espartana ser entendida como um processo de formação ao longo da vida, isto é, que se prolonga pela idade adulta (Lyc. 24), era entre os 7 e os 20 anos que decorria o que chamaríamos de ensino obrigatório dos futuros cidadãos espartanos. Plutarco individualiza quatro escalóes. A primeira etapa iniciase aos sete anos e a segunda aos doze. Quer numa quer noutra os indivíduos são considerados paides. Contudo, os mais velhos dos rapazes, isto é, aqueles que se encontram no ano imediatamente anterior ao que deixam de ser paides e passam a ser eirenes, são os melleirenes. Se aqueles são os que têm vinte anos, estes estão nos dezanove ( $L y c$. 17. 3). Dentro de cada escalão, os rapazes são divididos por 'grupos' (ảyć $\chi \propto$ l, que à letra significa 'rebanhos'). No caso do escaláo mais jovem, é eleito no seio do grupo um chefe, cargo consignado ao mais inteligente e ao mais valente em combate ( $L y c$. 16. 8). Já os rapazes que integram os grupos do escaláo 
que vai dos 12 aos 18 vão buscar os seus chefes fora do seu escaláo. Escolhem aquele que consideram o mais sensato e aguerrido dos eirenes (Lyc. 17. 2) $)^{5}$. Repare-se, em ambos os casos, no cuidado, pelo menos teórico, de Plutarco em sublinhar o equilíbrio entre a parte espiritual e física de um líder.

Disciplina, obediência, resistênciae combatividade são os valores inculcados nos formandos através de métodos e treinos rigorosos, de que o biógrafo destaca exemplos ilustrativos: despojamento dos confortos proporcionados por roupa, mobília e alimentação. Para além de usarem o cabelo rapado e andarem descalços, os instruendos praticam jogos nus, situação que se agrava a partir dos doze anos, altura em que prazeres como o banho e os unguentos se tornam raros, e em que, privados de vestir a túnica, passam a ter um único manto para todo o ano (Lyc. 16. 11-14). Deitam-se no chão, em leitos de plantas, feitos por eles próprios. As refeiçôes são parcas, muitas vezes conseguidas à custa do roubo, constrangimentos que os ensinam a defender-se da fome e estimulam a audácia e a astúcia (idem, 17. 4-6). Numa observaçáo curiosa para o leitor moderno, constantemente alertado para os prejuízos causados à saúde pelo consumo excessivo de alimentos, Plutarco refere que um efeito secundário da 'alimentação frugal'

${ }^{5}$ Embora abaixo dos eirenes venha identificado o grupo dos 'quase-eirenes' (melleirenes, à letra: 'os que hão-de ser eirenes'), nenhuma referência é feita ao seu modo de vida. Sobre a evoluçâo e partição em vários escalôes da agoge, vd. Kennell (1995: 28-48). 
(oligositia) é levar ao desenvolvimento físico (idem, 17. 7). Ao que se depreende, uma alimentação pouco abundante faz bem à saúde!

Com o fim da adolescência (i.e., a fase em que são denominados epheboi) e a passagem ao grupo dos eirenes, correspondente à categoria de jovens soldados, a agoge torna-se menos árdua (idem, 22). Ou seja, incentiva e consente aos neoi (= eirenes) o que proibia aos paides. No esplendor das suas figuras belas e bem arranjadas, os jovens guerreiros espartanos espelham a sua superioridade militar. Deixam crescer os cabelos, que tratam com esmero, sobretudo em momentos de guerra; engalanam as armas e os mantos. Também os exercícios físicos são aligeirados. No âmbito das referências a este modo de vida mais suave, há que não esquecer as regalias dos eirenes escolhidos para chefes de bandos de rapazes: dispóem dos serviços de preparação das refeiçôes dos paides que comandam (idem, 17. 4) e entregam-lhes, também a eles, a animação musical das mesmas (idem, 18. 3). O biógrafo não pode, pois, deixar de sublinhar a originalidade do sistema educativo dos Espartanos, na medida em que eles eram os únicos indivíduos para quem a guerra significava descansar dos exercícios de preparação para a mesma (idem, 22.3).

Como referimos acima, apesar de fortemente orientada para a preparação física, a agoge não oblitera a componente intelectual. Embora vagas, as informaçóes sobre esta matéria contemplam os domínios da comunicação e das artes. Sobre o conhecimento das letras (grammata), diz-se que estava reduzido ao estritamente 
necessário (idem, 16. 10). No entanto, simplicidade não significa incúria no ensino do poder da palavra. Esta deve ser usada com precisão, produzindo discursos concisos, mas profundos em sentido, a que corresponde

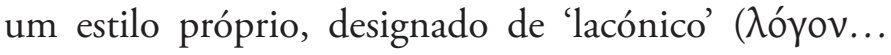

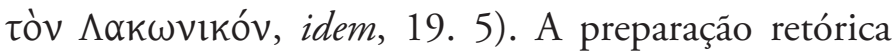
dos rapazes não era entregue a profissionais na matéria, como acontecia pelo resto do mundo greco-romano, mas aos seus formadores: os eirenes (que os treinavam a dar respostas ponderadas sobre matérias de interesse público, idem, 18. 3-5) e os adultos (que permitiam a sua presença nas messes, os syssitia, locais de convívio e discussão da vida política, assim transformados em verdadeiras 'escolas de bom senso', $\delta 1 \delta \alpha \sigma \kappa \alpha \lambda \varepsilon \tilde{\imath} \alpha$

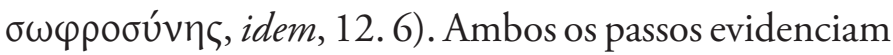
o cuidado colocado na formação cívica dos jovens.

O canto e a poesia são as áreas artísticas que integram a agoge. A simplicidade formal e o pendor moralizante das composiçóes continuam a ser, tal como no discurso, os seus elementos característicos. Combatendo a opiniáo comum de uma cultura espartana puramente militarista, Plutarco reconhece aos Lacedemónios (idem, 21.6) não só o título de 'os mais aguerridos' (polemikotatoi), mas também de 'muitíssimo cultos' (mousikotatoi) ${ }^{6}$.

Certamente devido ao seu carácter extraordinário no contexto da época, a educação das raparigas (parthenoi) espartanas corresponde à descrição mais

${ }^{6}$ Cf. Stadter (in Waterfield and Stadter 1998: 390, n. 31). 
extensa das Vidas sobre a paideia feminina (idem, 14). Aliás, Plutarco é explícito na afirmação de que essa formação possui uma natureza única e contrária ao padrão corrente. Como ele próprio esclarece, Licurgo determinou que as raparigas recebessem uma educação que punha de parte os atributos visados pelo modelo comum, a saber (14. 4): 'delicadeza' ( $\theta \rho u ́ \psi ı \varsigma)$, uma vida dentro de casa, isto é, 'sob a protecção das sombras' (a

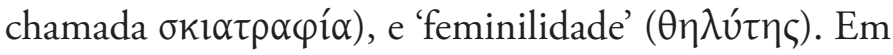
vez de uma educação feminina, as parthenoi espartanas são educadas de forma idêntica à dos rapazes. Uma boa preparaçáo física conseguem-na exercitando o corpo através da prática de diversas modalidades de atletismo (corrida, luta, lançamento do disco e do dardo). A força ( $\rho \omega ́ \mu \eta)$ que adquirem tem dois objectivos concretos: a perfeição da raça (mães saudáveis produzem filhos saudáveis) e facilitar o trabalho de parto (mães fortes suportam melhor as dores). A educação das jovens visa, tal como a dos rapazes, o que poderíamos chamar de culto do corpo e que Plutarco designa por enexia ('boa condição', 14. 7). Todavia a boa forma física não se almeja apenas pelos benefícios concretos que traz, mas também para ser publicamente exibida. A ocasião para essa mostra eram as paradas em que jovens dos dois sexos desfilavam nus ou sumariamente vestidos (ibidem) ${ }^{7}$.

7 O termo usado por Plutarco, gymnos, tanto pode significar 'nu', como 'sem a roupa ou equipamento usuais', o que quer dizer que, ainda assim, tinham alguma coisa vestida (Stadter, in Waterfield and Stadter 1998: 387, n. 22). 
Quanto à componente intelectual e artística da formação das parthenoi, inclui dança e canto, artes executadas no âmbito de festividades religiosas. Em suma, sujeito a uma educaçáo similar à dos rapazes, o género feminino pauta o seu código de valores pelos mesmos dos homens: 'excelência' (arete) e 'ambição' (philotimia).

Asdemaisinformaçóes das Vidassobre os conteúdos formativos da educação de Gregos e Romanos, além de bastante sumárias, confirmam a aposta em exercícios de corpo e do espírito. Para apurarmos o essencial da formação de um jovem comecemos por considerar os passos em que se dá conta da educação ministrada a um estrangeiro. A este há que dotá-lo dos saberes que viabilizem a sua aculturação, isto é, que promovam a aquisição de uma nova identidade. Essa nova identidade pode mesmo transformar-se no melhor prémio que um cativo pode receber. É precisamente nestes termos que se refere em Caes. 55. 3 a sorte do ainda filho pequenino (o bebé ou nepios) do rei númida Juba I. Ao ser educado na pátria do conquistador, pôde atingir 'o mais afortunado dos cativeiros', pois acabou por ser considerado 'um dos mais sábios escritores gregos' (por ser nesse idioma que redigia, a língua da elite da época).

Alexandre e Sertório são outros dois exemplos a considerar de promotores da educação dos filhos dos povos conquistados segundo a paideia pátria (paideia patrios, cf. Aem. 6. 8). Expoente máximo da expansão da cultura helenística, Alexandre determina que trinta mil rapazes persas aprendam o idioma grego (grammata... 
Hellenika) e sejam treinados no manejo das armas macedónias (Alex. 47. 6). Cá temos a preocupação constante em preparar os meninos para uma das suas principais funçóes, a de soldados. Do lado romano, encontramos Sertório a determinar a formação de alguns filhos de Iberos nas duas áreas de conhecimento em que, após a conquista romana da Grécia, um Romano culto devia ser industriado: os estudos (mathemata) helenos e romanos (Sert. 14. 3).

Essa bipolaridade cultural não colheu, no entanto, o entusiasmo de todos os patriarcas romanos. No seio da mais alta sociedade encontramos duas personalidade que espelham posições antagónicas em matéria de sistema educativo a ministrar aos filhos. Catão Censor, retratado como acérrimo resistente à influência da cultura grega, toma a seu cargo a função de mestre do filho nas várias áreas de conhecimento em que se devia formar (Cat. Ma. 20. 5). Antes de mais, as letras (grammata, 20.6), desempenhando a função habitualmente consignada ao mestre escola (gr. grammatistes). Chega mesmo a escrever um manual de história em letras maiúsculas, o que facilitaria o interesse do menino pelas gestas dos seus antepassados (20. 7). Ainda no domínio da formação intelectual, inclui-se o estudo das leis, regra geral da competência de um professor de direito (nomodidaktes, 20. 6) ${ }^{8}$. No domínio

${ }^{8}$ Desde a infância que as crianças aprendiam de cor os fundamentos da ciência jurídica, as Leis das XII Tábuas (Cic., Leg. 2. 59). 
da preparação física, também o mestre de educação física (gymnastes) é dispensado, embora as suas competências sejam transmitidas por Catão, que industria o filho nos tradicionais lançamento do dardo, combate armado e montar (ibidem). Todos estes exercícios, como é fácil de deduzir, têm uma componente utilitária óbvia, a preparaçáo física do futuro soldado. Apesar de, nos meios nobres, a educação física não se limitar a essa função prática, a verdade é que nunca, como na Grécia, pátria dos concursos de atletismo, ganhou grande expressáo a prática desportiva de cidadãos para fins competitivos ou de exibição (Marrou 1965: 351-352). Arato de Sícion exemplifica bem a paixão da aristocracia grega pelas competiçóes atléticas (Arat. 3. 1). Estes treinos, executados na palestra, faziam parte da formação liberal ( $\varepsilon \lambda \varepsilon v \theta \varepsilon \rho i ́ \omega \varsigma)$ dos jovens, permitindo que os corpos

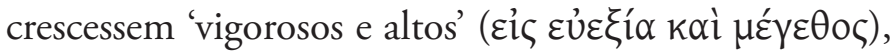
a ponto de poderem vir a alcançar a coroa da vitória, como sucedeu a Arato no concurso do pentatlo?.

Voltando à componente militar dos treinos físicos, recorde-se que havia em Roma um espaço especializado

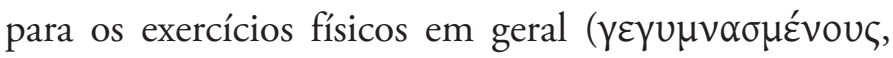
Cic. 44. 5) e militares, com armas e a cavalo, o Campo de Marte (Mar. 34. 5). Do elenco dos exercícios náo convencionais a que Catão sujeitava o filho parecem fazer parte os treinos enumerados após a expressão

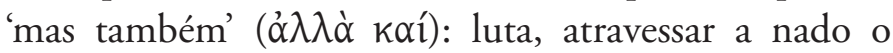
Tibre tumultuoso e aprender a suportar o calor e o frio

${ }^{9}$ Assunto retomado infra, sob a rubrica "Locais de formação". 
(Cat. Ma. 20. 6). Retomemos a questão da oposição do Censor 'a todas as formas de cultura e educação

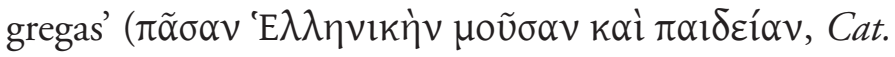
Ma. 23. 1), uma vez que contrasta nitidamente com a atitude de Emílio Paulo e com o caminho por que enveredariam, no futuro e em geral, os Romanos (a ponto de, ao tempo de Plutarco, cerca de quatro séculos mais tarde, o escritor afirmar que Roma 'se apropriara convenientemente de todos os ensinamentos e educação

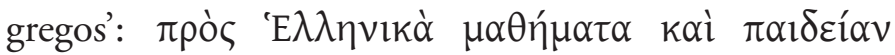

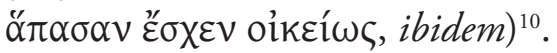

Para Catão Censor, e conforme se percebe pelo teor da educação ministrada ao filho, a paideia deve ser orientada para um objectivo moral (a aquisição da 'excelência' ou arete) e um resultado prático (a realização de feitos militares, i. e., a capacidade de mostrar a sua qualidade de aner agathos, 'homem distinto', em campo de batalha, Cat. Ma. 20. 10). Daí que a aposta da educação grega na eloquência (fulcral no programa formativo das escolas filosóficas que ao seu tempo começavam a implantar-se em Roma) lhe pareça 'desviar

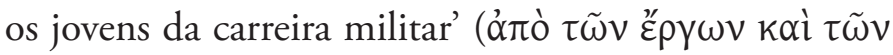

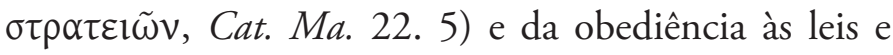

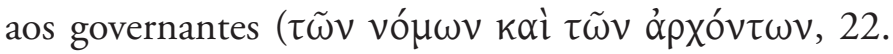

${ }^{10}$ Sobre a penetraçáo do helenismo na cultura e educação gregas, vd. Ferrary (1988) e Gruen (1992). Em particular sobre o papel preponderante que nesse movimento teve o ciclo de intelectuais de que se rodeou Cipião Emiliano, filho de Emílio Paulo adoptado por Cipião Africano, vide Marrou (1965: 365-373), Grimal (1975) e Henrichs (1995). 
7) ${ }^{11}$. O discurso radical da sua aversão à cultura helénica manifesta-se no vaticínio ameaçador de que a destruição dos Romanos residiria na adesão ao ensino grego (23. 2).

Contudo nem todos os Romanos tinham essa visão pessimista sobre os resultados de aderir à educação grega, que viam como uma forma de complementar 'a

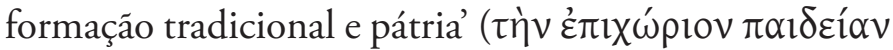

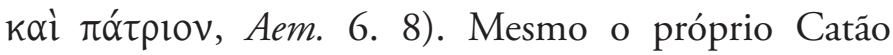
haveria de sucumbir, já na velhice, ao encanto das letras gregas (em particular a Demóstenes e Tucídides, Cat. Ma. 2. 5). Mas centremo-nos num paradigma diverso face à paideia helenística. Não obstante partilhar com o Censor a qualidade de ser um pai dedicado, Emílio Paulo limita-se a assistir aos treinos e exercícios dos filhos, entregando a mestres gregos a formação multifacetada que recebem (Aem. 6. 9). As áreas de formação indicadas e o emprego do substantivo neaniskoi para designar os filhos do Romano denunciam que a fase etária é a da

11 Recorde-se que Catão foi o responsável por persuadir o Senado a promulgar um decreto de expulsão de embaixadores filósofos vindos de Atenas (Cat. Ma. 22. 5-7), em 154 a. C. No entanto esse repúdio oficial tem dois precedentes que revelam a resistência da facção mais conservadora da sociedade romana às novas correntes de cultura, vindas da Grécia: em 173 foram banidos os filósofos epicuristas Álcio e Filisco; em 161 deu-se a expulsão de todos os rétores e filósofos gregos (Suet. Gram. 25, 1; Gell. 15. 11). Do lado oposto da barricada temos os esforços vários de cidadáos romanos para conseguir o estabelecimento legal desses homens de pensamento em Roma. Veja-se, por exemplo, o caso do peripatético Cratipo, para quem Cícero obteve a cidadania ( $\mathrm{Cic}$. 24. 7). 
juventude e não a da infância, como sucedia no caso do filho de Catão. Não se trata de ensinar uma criança a ler e de fortalecer o seu corpo de menino, mas de preparar jovens segundo as exigências refinadas da aristocracia. Assim, os estudos, a este nível médio e superior, incidem sobre a literatura ${ }^{12}$ (matérias que se incluem num ensino de tipo secundário, asseguradas por grammatikoi), a filosofia e a retórica (pertencentes à formação superior e entregues a sophistai e rhetores). O âmbito das artes também não é descurado, cabendo a escultores (plastai) e a pintores (zographai) a educação dos jovens patrícios. Contudo é de referir que o ensino das artes plásticas tinha, mesmo na educação helenística, um papel secundário (Marrou 1965: 363).

A preparação física continua a ser uma constante na formação. No entanto é de notar a particularidade de a actividade praticada revelar o estatuto social elevado da família. A caça, para a qual o pai arranja professores (didaskaloi), é sem dúvida um desporto chic, reservado às famílias aristocráticas já desde os tempos primordiais dos heróis homéricos (Marrou 1965: 77). O vocábulo grego para designar essa prática (kynegesia) denuncia, no primeiro termo que o compóe (kyn-), o papel fulcral que nela tinha o cáo (gr. kúwv, kuvó $)$. No caso dos Romanos, a caça fazia-se tanto a pé, mesmo por

${ }^{12}$ A instrução dos filhos há-de torná-los verdadeiros 'amantes

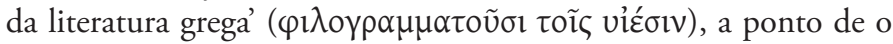
pai lhes vir a oferecer como recompensa de guerra pela vitória sobre o rei macedónio Perseu o prémio de retirarem para si os livros que quisessem da biblioteca real (Aem. 28. 11). 
membros de classes elevadas (Green 1996: 225), como a cavalo. Como imortalizou o poeta Horácio num dos seus versos, a caça é um campo de treino militar para o cidadão romano (militia Romana, Sat. 2. 2. 9-10). Esse era um treino obrigatório para os jovens de qualquer classe social (Green 1996: 227). Contudo, não é demais reforçar que, nos meios aristocráticos, a caça era também encarada como um desporto, mas que nem mesmo esta perspectiva deve ser tida como uma importação helénica, mas sim como um traço comum a civilizaçóes vizinhas (Vilanovenses, Etruscos, Latinos e Gregos) e que partilharam experiências (Green 1996: 237, 251). Compreendemos, assim, que o zelo de Emílio Paulo por uma preparação dos filhos nas artes nobres da caça e do hipismo o tenha levado a possuir uma criaçáo particular de potros e cachorros, que entrega à superintendência de encarregados também gregos (Aem. 6.9 9) ${ }^{13}$.

Claro que um objectivo incontestável da caça é ajudar ao fortalecimento físico e é uma actividade considerada não do quadro da formação escolar regular, mas de ocupação de 'tempos livres' (gr. $\sigma x 0 \lambda \eta ́$, correspondente em lat. a otium). Disso nos dá conta um passo da Vida de Filopémen (cap. 4. 2), onde colhemos

${ }^{13}$ Sobre o prestígio e o desenvolvimento da arte da cavalaria (sobretudo para fins militares) na Grécia desde os tempos imemoriais dos Poemas Homéricos até ao séc. IV a. C, com o Império Macedónio, cf. Hyland 2003: 126-163. Não é, pois, de estranhar que, também em questôes de treino dos filhos na arte de montar e para criadores de cavalos, Emílio Paulo tenha eleito mestres gregos. 
uma outra informação um tanto surpreendente (pelo menos à luz da mentalidade actual) quanto à forma de tornar o corpo mais ágil e vigoroso: os trabalhos agrícolas. Tal não significa que tenham sido descuradas as duas grandes valências pretendidas para a educação de um jovem grego: a de ser um cidadáo empenhado e um soldado competente. No que toca à formação do espírito, esta foi coberta pelos principais ramos da formação do adolescente (antipais), a filosofia e a literatura. No caso da primeira coube-lhe a orientaçáo de dois mestres académicos, Ecdelo e Demófanes ${ }^{14}$. Note-se que a formação filosófica ministrada se adequa perfeitamente ao carácter interventivo da personagem, pois foi claramente orientada para a 'vida política e para

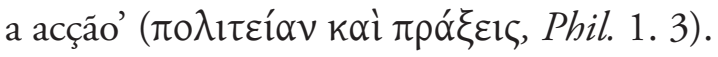

As liçóes dos filósofos continuou a ouvi-las e a ler as suas obras ao longo da vida, mas apenas aquelas que o ajudavam a atingir a excelência (arete). E a esfera da virtude que Filopémen almeja é uma só, a guerreira. Aliás, essa sua obsessão manifesta-se, 'desde a infância' (દ̇k $\pi \alpha 1 \delta o ́ \varsigma)$, a ponto de ser apelidado de 'apaixonado

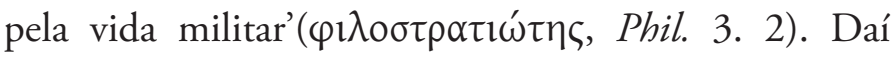

${ }_{14}$ Recorde-se que, quando se refere aos mestres que mais influenciaram Péricles, Plutarco, para além de indicar um hipotético músico (embora para Plutarco essa arte fosse apenas um disfarce para a sua verdadeira doutrina, a sofística), confere relevo especial aos nomes grandes de Zenáo de Eleia e, sobretudo, Anaxágoras de Clazómenas (Per. 4. 5). As grandes virtudes desta formação espiritual traduziram-se na capacidade de elaborar discursos irrepreensíveis e de ser uma pessoa de calma e tolerância exemplares para com quem o insultasse na praça pública (Per. 5. 1-2). 
que as matérias a que se dedicou com empenho tenham sido os seguintes treinos físicos: o combate com armas (ó $\pi \lambda o \mu \alpha \chi \varepsilon \tilde{\imath} v)$, a equitação (i $\pi \pi \varepsilon v ́ \varepsilon \mathfrak{l}$ ) e a luta ( $\pi \alpha \lambda \alpha i ́ \varepsilon ı v, 3.3)$, embora esta venha a abandonála por considerá-la prejudicial a um soldado (3. 5) ${ }^{15}$. É essa preferência exclusiva pela formação bélica que o leva a tomar uma atitude radical: abandonar a educação tradicional, ministrada por professores e supervisionada por pedagogos, e a ter "liçóes práticas" de combate, participando em expediçóes da sua cidade, Megalópolis, contra a Lacedemónia (Phil. 4. 1). Era de tal ordem o seu fascínio pela vida militar que mesmo as preferências literárias acabaram por reflectir uma tal vocação. Seleccionava dos Poemas Homéricos os passos que estimulavam o 'espírito combativo' (andreia), interessava-lhe o manual de táctica militar de Evângelo e as histórias que circulavam sobre um dos maiores estrategas do Mundo Antigo, Alexandre Magno (Phil. 4. 7-8). Náo restam dúvidas de que estamos perante

${ }^{15}$ A equitação era uma actividade em que as crianças romanas das famílias aristocráticas desde cedo se exercitavam, conforme atestam os referidos casos dos filhos de Catão, Emílio Paulo, Filopémen e o próprio Júlio César. Deste conta-se que montar foi 'desde a infância' (દ’k $\pi \alpha 1 \delta o ́ \varsigma)$ uma actividade fácil, a ponto de conseguir executar manobras de verdadeiro malabarista, como era cavalgar a uma velocidade máxima segurando as mãos atrás da cabeça ou cruzadas sobre o peito (Caes. 17. 6). É também de lembrar que a paixão pelo hipismo ganhou contornos de festival aristocrático

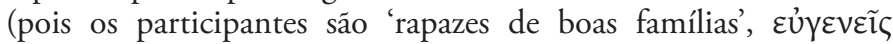
$\pi \alpha \tilde{i} \delta \alpha \varsigma$ (Cat. Mi. 3. 1). Tratava-se do ludus Troiae, instituído em 81 a. C. 
uma educação selectiva, pois foge ao padrão comum da bipolaridade entre armas e letras, almejada tanto por Gregos como por Romanos.

Tal como Filopémen, basta-nos enumerar mais dois Romanos ilustres que preferiram a carreira militar, impulsionados pela destreza ímpar revelada nesse domínio. Assim, Sertório (Sert. 2. 3), como qualquer Romano de boas famílias, dedica-se ao estudo da oratória e às leis, que lhe abririam portas para uma das carreiras mais almejadas (além da política e da militar), a de causídico. Um passo da Vida de Luculo dá conta de que há uma gradação a respeitar: antes de se enveredar pela carreira política, os Romanos viam com bons olhos que

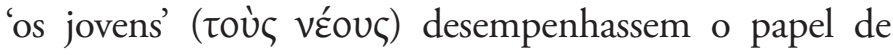
advogados de acusação de criminosos, treino que lhes desenvolveria a agressividade e capacidade de defesa, conforme se depreende da comparação estabelecida entre essa actividade e as lutas entre cachorros de caça e animais selvagens (Luc. 1. 2-3). Cícero é um bom exemplo do percurso formativo que o jovem romano seguia, 'depois de terminados os estudos da infância' ( $\alpha \pi \alpha \lambda \lambda \alpha \gamma \varepsilon i \zeta$

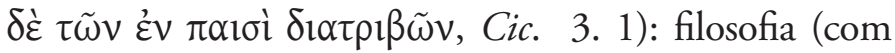
o académico Fílon), estágio forense, a que os Latinos davam o nome de tirocinium fori (sob a orientação de um dos nomes grandes do senado, Múcio Sévola, idem, 3. 2), e, por fim, o serviço militar (sob as ordens de Sula, idem, 3. 3). Há, no entanto, que considerar que, num conselho como aquele que o velho Demóstenes (exilado de Atenas) dá aos jovens que procuram aprender consigo (e que é de se afastarem da vida política, Dem. 26. 7), obtemos a 
confirmação de que o destino natural do jovem de boas famílias era mesmo servir 'a constituição' da sua cidade

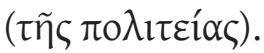

Outra figura famosa de general, 'desde tenra idade'

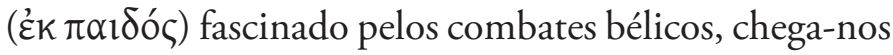
dos anais de Roma: Coriolano. Por considerar que a sua mais poderosa arma consistia no vigor físico, treinouse intensamente em todas as formas de luta (Cor. 2). À imagem de Filopémen, o que Coriolano ambiciona é uma forma física que lhe sirva o objectivo desejado: sair-se bem nos combates corpo a corpo com o inimigo. Tanto a corrida, como a luta, são treinos que favorecem a concretização de semelhante anseio.

Ainda sem sairmos do tema da preparação militar das crianças, vejamos como esta, mesmo que o discurso de Plutarco possa estar revestido de algum exagero, se inicia o mais precocemente possível. A propósito da educação dos filhos do rei Pirro do Epiro, não só se diz que, tal como Catão Censor, também ele se encarregou directamente dessa missão, mas sobretudo que "'logo

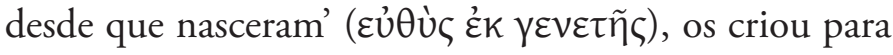
serem 'todos valentes no manejo das armas e fogosos'

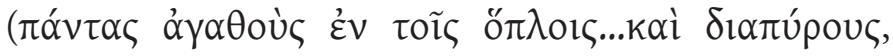
Pyrrh. 9. 4).

Para o final desta reflexão sobre os conteúdos da paideia, reservámos a figura a todos os níveis excepcional de Alexandre Magno. Plutarco, na referência que faz ao assunto, deixa bem evidente que a decisão de Filipe da Macedónia baseou-se em algo que já vimos, quando iniciamos o estudo deste capítulo: a educação é um 


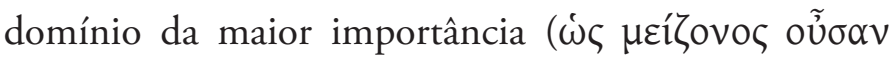

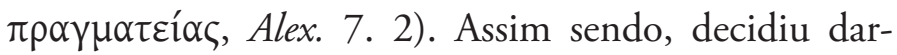
lhe uma formação também ela excepcional, i. e., que póe de parte o ensino habitual: os estudos culturais (ou, como os Gregos lhes chamavam, as artes das musas, a mousike $e^{16}$ ) e o 'currículo tradicional' (a enkyklios paideia, em cujo plano ideal sempre figuraram tanto as letras como as ciências matemáticas) ${ }^{17}$. As razóes por que o faz devem não ser obliteradas, pois continuam a ser válidas actualmente, no momento em que os progenitores (que podem) decidem sobre o que vai ser ensinado e quem vai ensinar o(s) seu(s) filho(s)! Por conhecer bem a natureza (physis) do filho, sabia que uma educação baseada na

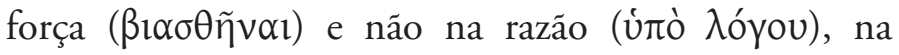

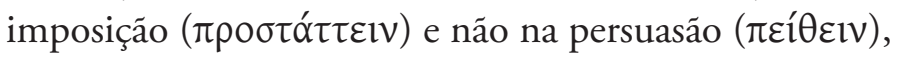
não se lhe adequava (Alex. 7. 1). A mesma ideia, de que um jovem é mais facilmente persuadido a seguir

${ }^{16} \mathrm{Na}$ Época Clássica fixou-se em nove o seu número, sendo gradualmente atribuída a cada uma a supervisão de determinado domínio cultural. Geralmente é a seguinte a lista de atribuiçóes: a poesia a Calíope, a história a Clio, a pantomima a Polímnia, a flauta a Euterpe, a poesia ligeira e a dança a Terpsícore, a lírica coral a Érato, a tragédia a Melpómene, a comédia a Talia e a astronomia a Urânia. Vd. Grimal 1992: sub verbum "Musas".

${ }^{17}$ Não obstante as dificuldades em dar uma definição única ao conceito em si mesmo genérico de enkyklios paideia, nascido no Período Helenístico e que há-de estar na origem das sete artes liberais da Idade Média (o trivium e o quadrivium), no essencial o programa era constituído por três disciplinas de cariz literário (gramática, retórica e dialéctica) e por quatro de teor matemático (geometria, aritmética, astronomia e teoria musical) (Marrou 1965: 267). 
as orientaçôes de um mestre, caso este lhe apresente a razão de ser das coisas em vez de usar da violência das palmadas, é um motivo que reaparece em Cat. Mi. 1. 10 .

De facto um dos motivos adiantados por Plutarco para Catão Censor ter assumido a missão de educador do filho foi precisamente a sua aversão a que este fosse fisicamente castigado (com puxóes de orelhas) e repreendido por palavras pelo professor (Cat. Ma. 20. 6). Aliás, semelhante atitude combinava com o facto de abominar um pai que espancasse o filho e a esposa (idem, 20). No entanto o hábito de dar castigos corporais às crianças e jovens seria tão vulgar que Sertório (Pom. 18. 1), desdenhando da juventude do general romano Pompeio, afirma que as armas de que necessita para bater-se com ele são a verdasca e o bordão (i. e., não as de um soldado, mas de um mestre ou pai irado).

Porque financeiramente tinha capacidade para tal e porque possuía a visão de espírito superior para o fazer, Filipe decidiu contratar para mestre de Alexandre o mais conceituado filósofo de então, Aristóteles (Alex. 7. 2). Como se sabe, mais tarde, em Roma, a prática comum entre os jovens afortunados era aproveitarem as liçóes dos mestres gregos que se vinham fixar na urbe ou, melhor ainda, prosseguir os estudos superiores longe de casa, indo beber directamente à fonte. Vejamse os casos de Bruto e Marco António. Aquele recruta, como apoiantes para derrubar os adversários políticos, jovens romanos que, tal como ele, estavam a estudar

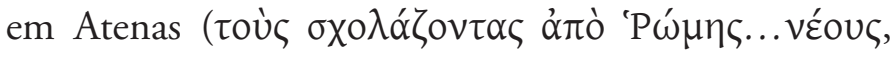


Brut. 24. 2). Este fora para a Grécia para prosseguir os estudos superiores em oratória (legein), mas também para treinar o corpo para concursos militares (Ant. 2. 7). Como ficamos a saber pela Vida de Cícero, havia também Romanos que, depois de instruídos com os mestres helenos, passavam a ministrar as suas liçóes aos jovens filhos das famílias mais nobres e proeminentes. No caso da figura em apreço, Cícero, Plutarco não esconde que essa era uma via usada pelo ambicioso romano para se aproximar do poder (Cic. 40. 1). Na mesma linha há que considerar que um dos mais poderosos e promissores discípulos de Cícero, Augusto, lhe foi entregue para

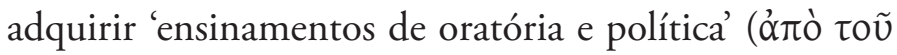

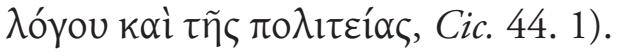

\section{Educadores}

O acompanhamento da primeira infância, que geralmente se prolongava até aos sete anos (cf. Lyc. 16. 7) ${ }^{18}$, estava entregue, por norma, às mulheres da casa: a mãe, alguma avó, se fosse caso disso, e as amas (de condição escrava). No que se refere às 'amas' ( estrangeiras, as mais famosas eram as Lacónias, por proporcionarem aos 'bebés' ( $\beta \rho \varepsilon ́ \varphi \eta)$ uma disciplina que os tornava mais cedo independentes e autónomos (contrárias ao enfaixamento dos recém-nascidos ${ }^{19}$,

${ }^{18}$ Sobre esta questão, vd. Marrou 1965: 218, Golden 1990: 14 e Rawson 2003: 135.

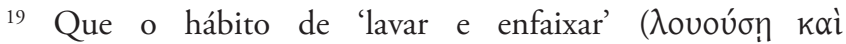

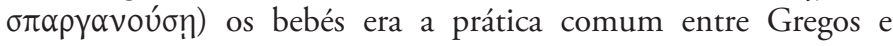


habituavam-nos a uma alimentação variada e a não temer o escuro e a solidão, bem como a não fazerem birras e a chorar). Alcibíades, entre outros, teve os primeiros cuidados entregues a uma dessas afamadas amas espartanas (idem, 16. 5).

São sobretudo três as mães mais célebres das Vidas pela afeição à prole e cuidado depositado na sua educação, atitude talvez acentuada pelo seu estatuto de viúvas: Rea, mãe de Sertório, Volúmnia, mãe de Coriolano, e Cornélia, mãe dos Gracos. Decidimos considerar primeiro Rea e Volúmnia por forma a respeitar o paralelo que a nível textual o próprio biógrafo estabelece, uma vez que diz, quase ipsis verbis, referindose a cada um dos meninos, 'foi (decentemente) criado pela mãe viúva' (

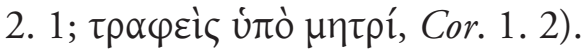

Para o final deste elenco de mães extremosas, guardei Cornélia, tanto pelo seu papel de educadora, como pelas qualidades reveladas no relacionamento com as suas doze crianças (que é o ponto que agora nos interessa considerar). Dela diz-se que 'criou com

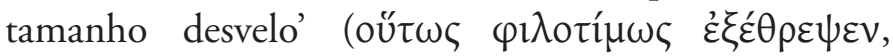
$T G$ 1. 7) os filhos que as virtudes que possuíam

Romanos, deduz-se não só do passo acabado de analisar, em que se enumeram as originalidades das amas lacónias, mas também em Cat. Ma. 20. Repare-se que em $L y c$. 16. 3 também se referia que os bebés eram lavados náo com água, mas com vinho, para lhes testar a robustez física. Outra alusão à lavagem do recém-nascido após o parto ocorre a propósito de um deus, Dioniso, mas náo deixa, por isso, de retratar uma prática da gente comum (Lys. 28. 7). 
'pareciam dever-se mais à educação do que à natureza'

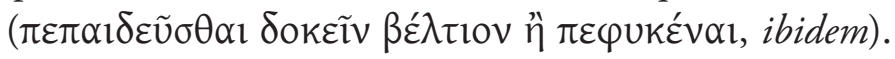
Este é, por certo, um dos mais rasgados elogios que se pode fazer a uma mãe, num contexto social em que a sua esfera de acção continuava, no que à gestáo dos bens patrimoniais e dos filhos diz respeito, na dependência directa de um 'senhor' (pai, irmão, cunhado ou até filho de maior idade). E as virtudes que Plutarco enumera para esta mãe (idem, 1-7), elevada, diríamos mesmo nós, a um estatuto quase lendário de heroína familiar, são as seguintes: 'sensatez' ( $\sigma \omega ́ \varphi \rho o v \alpha)$, 'amor aos filhos' (

Detenhamo-nos na exaltação do afecto à prole, para lembrar que dois progenitores do sexo masculino acima considerados devem agora ser evocados, uma vez que se elencam nos exemplos inequívocos (porque expressos por termos próprios) de semelhante característica (que mais não é do que a resposta à caracterização psicológica, feita supra, de crianças e jovens como 'amigos das mães'$\varphi \imath \lambda o \mu \eta ́ \tau \omega \rho \varepsilon \varsigma-$ e 'amigos dos pais' Duas das personagens em apreço provêm do mundo romano (Catão Censor e Emílio Paulo). Ao primeiro

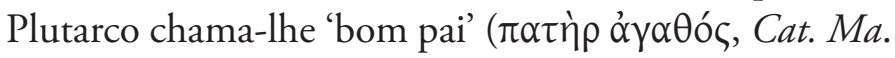
20. 1), ao segundo atribui a distinção de ser o Romano

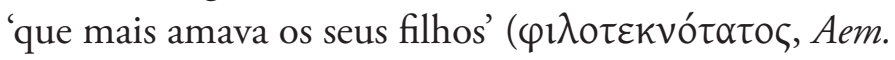
6. 10).

A estes há que juntar Agesilau, rei espartano, também denominado 'amigo dos filhos' (philoteknos, Ages. 25.11). A diferença para com as figuras anteriores reside no facto de continuarmos a ter progenitores/ 
educadores, mas que veiculam a formação através da brincadeira ${ }^{20}$. Sendo os filhos ainda pequeninos

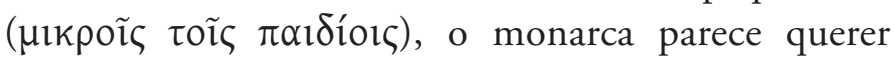
industriá-los numa das artes indispensáveis a futuros príncipes, a equitação. Mas esta é uma dedução puramente pessoal, pois, desde sempre e ainda hoje, mesmo que não pretendamos que os nossos filhos venham a saber montar, nada mais vulgar do que montarmos num pau e, com eles, simularmos uma cavalgada!

Claro que não é obrigatória a presença do vocábulo grego philoteknos, para encontrarmos nas Vidas numerosos exemplos desse afecto dos pais à prole. Evoco aqui um exemplo que me parece bastante ilustrativo da capacidade de abnegação mútua, ou seja, o sacrifício do filho (Antíoco), por respeito ao pai (Seleuco), e o deste por 'afeição' (eunoia) para com aquele (Demetr. 38. 5).

${ }^{20}$ Colocar crianças e adultos a brincarem juntos constitui, sem dúvida, uma forma de sociabilização e de aproximar os gostos e interesses de duas faixas etárias distintas, mas que necessariamente se relacionam no dia a dia. $\mathrm{O}$ contexto em que se insere a história recordada por Plutarco é festivo, logo de relaxe: a comemoraçáo de um aniversário (Cat. Mi. 2. 6). A ocasião, pelo menos nos meios mais abastados como era o caso da família de Catão de Útica, era assinalada por uma refeição, finda a qual havia lugar para o entretenimento. Aqui é que nos parece revelar-se o pendor didáctico do jogo escolhido, a encenação de julgamentos em tribunal, tanto

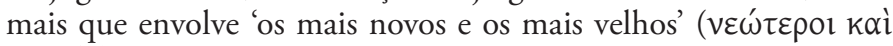
$\pi \rho \varepsilon \sigma \beta u ́ \tau \varepsilon \rho 01)$, como se uns pudessem orientar os outros, ao que nos atrevemos a deduzir! Este tipo de mimese ajusta-se bem à admiração que os Romanos tinham por que os filhos fizessem uma carreira de advocacia, conforme já vimos supra a propósito de Luc. 1. 2-3. 
Enquanto o jovem, enamorado pela também jovem madrasta (Estratonice), se deixa morrer de inaniçáo, fingindo-se doente, para não entrar em rivalidade com o pai, Seleuco, assim que o físico da corte lhe descobre a verdadeira causa da maleita do filho, profundamente emocionado e banhado em lágrimas, não só lhe entrega a esposa como o reino.

Por oposição a estes diversos exemplos de philoteknia ('amor aos filhos'), Plutarco aplica uma única vez nas Vitae o seu antónimo, a misoteknia. Atribui-a ao orador ateniense Demóstenes um seu rival, Ésquines, a quem pareceu um acto de falta de afecto pela filha o facto de, apenas volvidos seis dias sobre o falecimento da menina, este comemorar a morte de Filipe da Macedónia exibindo-se em público esplendidamente vestido e coroado (Dem. 22. 3). Contudo, a observação com que Plutarco prossegue desacredita os fundamentos das censuras tecidas ao pai, ao observar que as manifestaçóes de luto e os lamentos não são sinais, i. e., provas de uma 'alma que ama os seus' ( sim, sentenciar a sua morte por envenenamento (como fez Mitridates a Ariárates, Pom. 37. 2), situação que também se coloca precisamente ao contrário (com o filho a oferecer ao pai um bolo envenenado, Cic. 26. 7). Claro que a ambição pelo poder e os receios de que os herdeiros quisessem apoderar-se de algo que só lhes viria parar às máos por morte dos progenitores devem ser muitas vezes considerados um móbil forte por detrás destes parricídios e filicídios relativamente 
comuns em meios corrompidos pela ambição doentia de $\operatorname{poder}^{21}$.

Mas retomemos o assunto das mães extremosas. Neste ponto náo se pode silenciar uma atitude particular e, seguramente, sui generis relativamente ao padráo corrente, tomada pela esposa de Catão Censor. De facto, podemos dizer que se assiste a uma inversão de papéis entre a mãe e a ama, uma vez que aquela muitas vezes amamentava os bebés das escravas. $\mathrm{O}$ interessante é notar que esta prática não se deve a eventuais razóes de ordem biológica, mas sim de ordem moral. Tornando os escravos e o seu futuro senhor irmãos de leite, mais facilmente se criavam laços de lealdade daqueles para com este (Cat. Ma. 20. 5).

Também as avós, que partilham a casa com a família de um descendente, podem revelar-se um apoio útil e apreciado pelas crianças. Veja-se a mãe de Coriolano, apresentada no centro do círculo das mulheres da casa, com os netos ao colo (Cor. 33. 4).

21 Paradigmático, por ser uma excepção na longa linha de homicídios no seio dos familiares mais próximos das famílias dos sucessores de Alexandre Magno, é Antígono. O seu excelente relacionamento e profundo afecto pelo filho Demétrio já foi acima mencionado a propósito de a este ser atribuído o adjectivo de philopator (Demetr. 3. 1). Plutarco acrescenta que, com a excepção de Filipe V (Demetr. 3. 4, Aem. 8. 9), que eliminou apenas um dos seus filhos, todos os sucessores de Alexandre primaram por numerosos exemplos de execução de filhos, mães, esposas e até irmãos. Como se diz expressamente no texto (Demetr. 3. 5), todos esses ataques à philia familiar foram cometidos com o intuito de preservar a segurança do rei. 
Voltemos a considerar o tema dos órfãos. Sendo, muitas vezes, o pai o sustentáculo financeiro da família e quem assume a responsabilidade de orientar a educação dos filhos, a condição de órfẫo é, também de regra, uma situação de desvantagem para as crianças que se vêem nessa condição. Desde logo ficam na dependência de

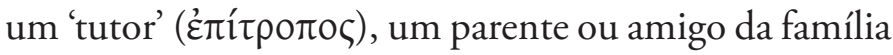
do sexo masculino, pois uma mulher não tem poderes legais para assumir os encargos que competiam a um pater familias romano ou kyrios grego $^{22}$. Nem sempre as coisas corriam bem sob a tutela do novo 'senhor' da criança. Prova inegável de semelhante regra é o caso relatado da infância de Demóstenes (Dem. 4. 4). Apesar de ter uma mãe atenta às fracas condições físicas do filho adoentado, que, juntamente com o apoio dos pedagogos, proibiu os esforços, a educação liberal - isto é, aquela que era ministrada a um 'rapaz de condição

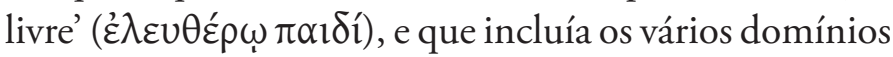

${ }^{22}$ Como se sabe, a falta de poder legal nunca serviu de obstáculo a que as esposas assumissem, no seio da família, uma autoridade a que os próprios maridos secreta ou abertamente reconheciam estar sujeitos. A esse propósito leiam-se as palavras atribuídas por Plutarco a duas grandes figuras de estado, o Romano Catão Censor (Cat. Ma. 8. 4: 'Todos os homens governam as suas mulheres, mas nós, apesar de governarmos todos os homens, são as nossas mulheres que nos governam') e o Ateniense Temístocles (idem, 8. 5: 'Mulher, os Atenienses governam os Gregos, eu os Atenienses, tu a mim, mas o teu filho a ti'). É de notar, nesta última fala, a referência a uma situação de inversão dos tradicionais papéis, segundo os quais deve ser a mãe a governar o filho e não o inverso. Estamos perante um quadro familiar que tem tanto de antigo quanto de actual: o da criança estragada com mimo. 
da formação física e intelectual já acima referidos ficou-lhe vedada, porque os tutores legais enganaramno, usurpando-lhe o pecúlio que lhe pertencia (a ponto de náo haver dinheiro para pagar aos didaskaloi). Mas o mais grave é que Demóstenes, ambicionando as liçôes do melhor mestre de retórica de então, não poderá custear as liçóes que tanto desejava ter com o orador Isócrates, precisamente 'devido à sua orfandade'

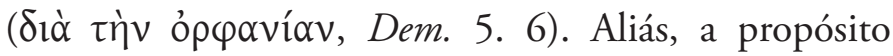
de Coriolano, fazia-se a observação geral de que 'ele tornou evidente que a orfandade pode ser contada entre

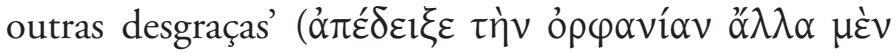

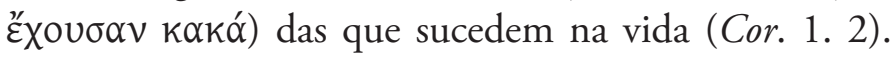
Ainda na Vida desta figura tomamos consciência de que a orfandade implica padecimento emocional e social, uma vez que, como o próprio lamenta, ao contrário do general tebano Epaminondas, quando atinge o auge do sucesso náo pode alcançar o cúmulo da felicidade: ter pai e mãe ambos vivos a assistir ao seu triunfo (Cor. 4. 6).

Quanto aos tutores, a sua necessidade coloca-se por morte do pai de um menor. É sua função zelar pelo património da criança, sua educação e, antes de tudo o mais, algo que pareceria demasiado óbvio para ter que ser referido, a sua vida. De facto náo é assim, em particular sob duas circunstâncias: a criança ser um herdeiro régio e, como tal, poder sempre haver pretendentes ao trono que desejem eliminá-lo; a cupidez dos guardióes sobrepor-se ao compromisso assumido, havendo registo de diversos pedagogos (temporariamente com funçóes 
práticas, não legais, equivalentes às de tutores) que não têm pejo de roubar e pôr em risco aqueles que deviam preservar.

No conjunto dos órfãos que têm familiares próximos por tutores, destacamos cinco situaçóes. Em todos os casos os órfãos são sobrinhos e os tutores tios. Comecemos por uma versão que Plutarco, embora não siga, acaba por recordar: a de Demétrio ser sobrinho e não filho de Antígono da Macedónia. O menino ainda era muito pequeno (um nepios), quando o pai morreu e a mãe casou com o cunhado, podendo passar, segundo a opiniáo de uma minoria, por essa via, a ser considerado seu legítimo filho (Demetr. 2. 1). Outro tio que toma a seu cargo 'a criação e a vida' ( três sobrinhos, entre os quais Catáo de Útica, é Lívio Druso (Cat. Mi. 1. 2). De Alcibíades diz-se apenas que

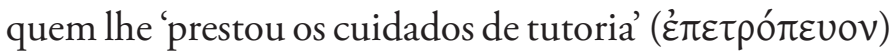
foram dois tios, Péricles e Árifron (Alc. 1. 2).

Consideremos, agora, tios de sobrinhos especiais, isto é de candidatos ao trono. Ser tutor de um herdeiro acarreta responsabilidades pessoais, mas também políticas, de não menor importância. Vejam-se os casos de dois espartanos, Licurgo e Leónidas. Após a morte do irmão sem herdeiro, Licurgo assume o trono, mas por pouco tempo (Lyc. 3). Ao saber que a cunhada se encontrava grávida, cumpre logo o seu principal papel de mentor, salva a criança de morrer antes de nascer, uma vez que a cunhada lhe oferecia o reino, bastando para tal ela abortar e Licurgo desposá-la. Assim que a criança, do sexo masculino (como tinha de ser para poder reinar), 
vem ao mundo, Licurgo senta-a de imediato no trono, reconhecendo-a como rei e reservando-se ao seu papel de tutor, com poder real (como era natural, atendendo à idade do soberano de direito). Apesar de a maioria dos Espartanos o ter na estima de homem honesto, alguns familiares do lado materno lançam a suspeita de que Licurgo era ambicioso a ponto de desejar o poder real para si, sendo capaz de atentar contra a vida da criança para atingir semelhante fim. Em prol do seu bom nome e da integridade da vida que lhe competia preservar exila-se voluntariamente, sob promessa de apenas regressar caso aquele falecesse sem ter gerado um herdeiro. Quanto a Leónidas, a sua história exemplifica a situação prevista por Licurgo. Na verdade, só ascendeu ao trono de Esparta, pela linha dos Agíadas, uma vez que o sobrinho-neto 'de quem tinha a tutoria' ( $\tau \grave{v} v$

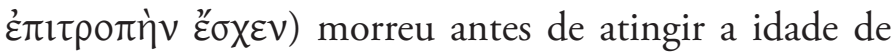
ser rei (Agis 3. 8).

Escolhas igualmente preferenciais para o cargo de tutores são indivíduos com quem o pai ou a família tenham tido, em vida do defunto, uma relação de proximidade, como sucede com a hospitalidade (xenia) e a amizade (philia $)^{23}$. Na verdade os sentidos de ambos os conceitos são de tal forma inclusivos entre si, isto é um hóspede torna-se num amigo e este, muitas vezes, acaba

${ }^{23}$ A produção bibliográfica sobre estes dois valores fundamentais da cultura grega é de tal forma vasta, que nos limitamos a indicar algumas referências ilustrativas: Oliveira 1973-74, Scott 1982, Blundell 1989, Konstan 1997, Belfiore 2000. 
também por se ver na condição de hóspede daquele, que, como veremos de seguida, os Gregos criaram um termo que os funde, a philoxenia.

Olímpia, avó do potencial herdeiro do trono da Macedónia, receando pela vida do filho de Alexandre, ainda menino (paidion), pede a Êmenes por carta que tome a criança a seu cargo e a crie (Eum. 13. 1). A relação da criança com o tutor náo tem de ser de sangue, como se vê desde já por este exemplo, uma vez que Êumenes provavelmente era filho de um hóspede e amigo ( $\delta i \grave{\alpha}$

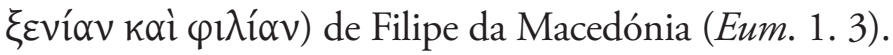
Também Filopémen recebe, por morte do pai, um tutor com uma relação de amizade e hospitalidade (philoxenia) com o seu progenitor (Phil. 1. 2). O já supra referido filho de Cábrias, estratego instrutor de Fócion, com quem certamente desenvolveu uma relação próxima de confiança, o pequeno Ctesipo, depois de órfẫo, teve por tutor o antigo instruendo do pai (Phoc. 7. 3).

Embora não se tratem já de tutores, mas de pedagogos, entendemos considerá-los a par destes, na medida em que, em casos especiais (ausência da figura paterna devido a razóes de variada ordem), são-lhes confiadas as vidas e os haveres de crianças que devem proteger. Outra mulher, certamente não menos famosa nem poderosa do que a mãe de Alexandre, Cleópatra, entrega a vida de um dos seus filhos, Cesarião, nas máos de um paidagogos, acompanhando esse acto de uma avultada quantia (Ant. 81. 4). No entanto, a cupidez do sujeito leva-o, ao contrário de Êumenes, a assumir a actuação de um traidor, entregando o jovem a Júlio César 
(que haveria de mandar matá-lo). Também Antilo, filho de Marco António e Fúlvia, pereceu devido ao igual mau carácter do pedagogo a cuja guarda fora entregue, acto que valeu a este último, depois de descoberto o roubo de uma jóia ao jovem, a crucificação (idem, 81. 2).

É caso para acrescentar que, não obstante os exemplos acabados de considerar, nem sempre são os tutores (ou figuras com essa missão) que causam a desgraça de quem devem estimar, substituindo-se, o melhor que podem, nas funçóes de um pai precocemente desaparecido. Uma história contada a propósito de Árron, um Etrusco, vem dar testemunho do 'azar' ( $\sigma u \mu \varphi \circ \rho \alpha ́)$ que o acolhimento de um meirakion trouxe ao tutor (Cam. 15. 4-6). A ingratidão resume-se ao facto de o jovem não só se envolver amorosamente com a esposa de Árron, mas em prosseguir com essa paixão a ponto de mover todas as influências que a sua vasta fortuna lhe proporcionava para, em tribunal, obter a sentença de ficar com ela para sua mulher.

Do que acima se acabou de relatar a propósito do pedagogo não se fique com a ideia errada de que eram homens de vil carácter. No geral não era assim. Basta-nos evocar um único testemunho, o do festival ateniense em honra de Teseu. Na véspera das festividades, até ao tempo de Plutarco, ainda era hábito sacrificar, em memória desse paedagogos exemplar, um carneiro (Thes. 4). Quanto à sua proveniência e condição, tanto Gregos como Romanos os escolhiam frequentemente entre os cativos de guerra que faziam. A informação que o biógrafo dá em matéria de pedagogos na agoge 
de Licurgo é esclarecedora de qual era a prática comum dos restantes Gregos (e podemos acrescentar também Romanos) ao afirmar o que os Espartanos não estavam autorizados a fazer (Lyc. 16. 7): comprá-los (como escravos que eram) ou pagar-lhes um salário (no caso de serem de condição livre), uma vez que os seus filhos lhes eram retirados para serem educados sob as regras e o controlo do Estado. Assim não se comportava a maioria dos Gregos, como bem prova a vida de Alcibíades, que teve por pedagogo Zópiro, segundo Platão ${ }^{24}$, um mero escravo (Lyc. 16. 6).

Tal como em todas as profissóes, o prestígio das mesmas não depende apenas dos seus autores, mas também da matéria prima que trabalham. Sendo Alexandre da Macedónia quem era, um parente do lado materno, Leónidas, indivíduo de carácter austero, não deprecia que lhe atribuam um título a que está ligada

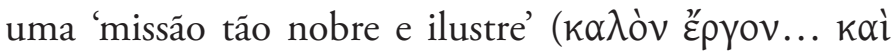

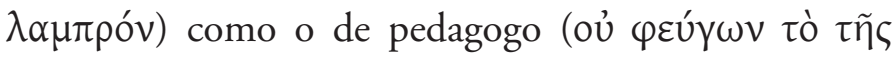

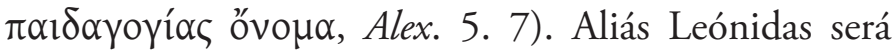
designado por 'pedagogo' ao longo da biografia (caps. 22 e 25). No entanto, pelo papel que desempenhou na educação do jovem, os títulos que lhe davam, talvez por acharem reflectir melhor o impacto que teve na sua

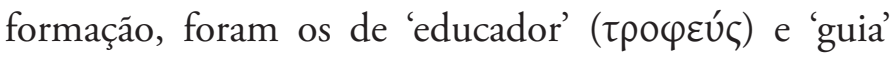

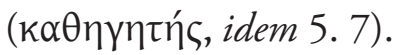

$\mathrm{O}$ cargo de pedagogo, mais humilde, pode ser entregue a um indivíduo mais limitado, ou como se lê no

${ }^{24}$ Alcibiades $122 \mathrm{~b}$. 
texto 'sem possuir nenhum refinamento especial' ( $\alpha \alpha \lambda \lambda_{0}$

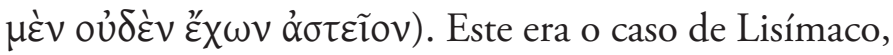
cujo único requisito, infantil, evocado para merecer o cargo de pedagogo era o de bajular o educando da maneira que ele mais apreciava, elevando-o ao estatuto do seu modelo, o herói da Ilíada (idem, 5. 8). Chamavalhe Aquiles, Peleu ao pai e a si Fénix. E Alexandre soube ser um aprendiz reconhecido, pois manifestou pelos dois pedagogos, de formas diversas, o grande apreço que lhes tinha. Ao primeiro entregou uma elevada quantidade de incenso e mirra, produtos bastante valiosos, como aquele lhe fizera saber nos tempos idos da infância (Alex. 25. 6-8). Ao segundo salvou-lhe a vida, tendo para tal, em plena campanha, abrandado a marcha por forma a que o velho pedagogo, já com poucas forças, não fosse deixado para trás pelo exército (idem, 24. 11).

Nem todos os pedagogos possuíam talento para o encargo exigente que sempre foi tomar conta de crianças, supervisionar-lhes as tarefas domésticas e escolares. Assim, havia aqueles pedagogos que, de tão desadequados que estavam à sua função, acabavam por ver o feitiço virar-se contra o feiticeiro, ou seja, as crianças espancavam-nos (Lyc. 30. 7), em vez de serem eles a ter o poder de aplicar as puniçôes físicas (Cat. Mi. 1. 10). Porém, como se evoca através de uma comparação na Vida de Marcelo (9. 7), um pedagogo é uma figura tutelar, que inspira respeito, sendo a sua principal função (pedagógica) ensinar o discípulo a

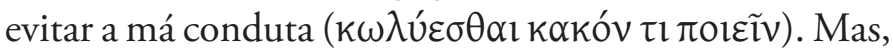
para se ser um bom pedagogo, não basta conseguir uma 
relação de respeito com a criança, muito menos baseada na violência. Ganhar a confiança do dono talvez seja o reconhecimento socialmente mais expressivo do valor do pedagogo. Assim sucedeu com Sicino, o escravo persa e pedagogo do filho de Temístocles, a quem o general entregou uma missão que só a um homem da maior confiança se pode dar: falar com Xerxes e persuadi-lo a avançar para Salamina (Them. 12. 4) ${ }^{25}$.

Em termos de competências e níveis de instrução do pedagogo, não podemos traçar um quadro geral, pois, como observa Rawson (2003: 165), "He was usually a slave but had to be carefully chosen for moral integrity, counscientiousness, and, if possible, some intellectual ability”. Ou seja, não era obrigatório possuir grande instrução. Acabámos de ver que Lisímaco era um rústico, mas também deparamos com o pedagogo dos filhos de Nicógenes, o homem mais rico da Eólia, apresentado como porta-voz dos deuses, cuja vontade exprime, tomado de delírio, sob a forma de versos (Them. 26. 2).

Os bons mestres - como vimos supra a propósito de Aristóteles (a quem Filipe da Macedónia entregou a educação do filho, cf. Alex. 7. 2) e de Demóstenes (que, graças ao roubo dos tutores, ficara sem dinheiro para pagar aos didaskaloi-Dem. 4. 3, pelo que não possuiria dez minas para custear as liçóes do orador Isócrates - Dem. 5. 6) - custam dinheiro. A fortuna pessoal é um argumento de peso para Plutarco acreditar que

${ }^{25}$ Heródoto dá conta deste episódio em VIII. 75. 
Fócion não provinha de progenitores humildes, pois, caso assim fosse, não teriam possuído os recursos que lhe proporcionaram 'a educação própria de um homem

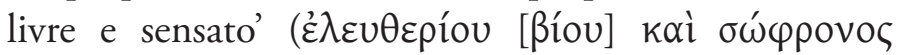

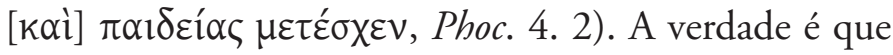
teve dois dos maiores mestres da Academia, Platão, o fundador, e Xenócrates, um dos seus sucessores. Aos filhos dos Atenienses que são exilados para Trezena a fim de escapar ao inimigo persa, os anfitrióes recebem-nos com tal cortesia que, entre as graças que lhes concedem,

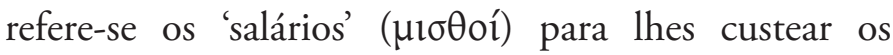
didaskaloi (Them. 10. 5)

\section{Locais de formação}

Os locais em que se ministra o ensino e se adquire formação nas mais variadíssimas áreas (desde as letras, passando pelo treino físico de vária ordem, incluído o militar, até chegar aos níveis mais elevados da oratória e da filosofia), conforme fomos oportunamente indicando, caracterizam-se pela variedade. Não me deterei nas referências residuais aos espaços privados em que eram educadas as crianças gregas e romanas ou seja a casa (Cat. Ma. 20 e Aem. 6. 8-10) e a escola (gerida por didaskaloi). Importa, sim, atentar no número significativo de passos em que se identificam espaços públicos aproveitados para formar os futuros cidadáos adultos, tanto do ponto de vista da boa preparação física que, enquanto potencial soldado, deve possuir, como da formação intelectual, valência indispensável ao seu bom desempenho na vida activa política. 
Dos locais frequentados pelos jovens, tendo em vista a aquisição do que se designa de "educação liberal"26, são três os mais procurados (a avaliar pela sua maior

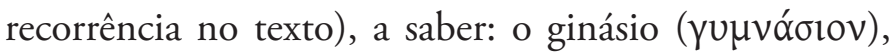
a palestra $(\pi \alpha \lambda \alpha i ́ \sigma \tau \rho \alpha)$ e o pórtico $(\sigma \tau o \alpha)^{27}$. No cap. 7 (\$5) da Vida de Timoleonte, Plutarco oferece ao seu leitor precisamente uma referência conjunta a estes três espaços públicos, trecho em que é de imediato evidente que o primeiro é destinado a uma faixa etária específica, os 'jovens'. Igual remissão para o grupo dos neoi surge mais adiante nesta mesma Vida (39. 6), bem como em Pel. 7. 5. Esses frequentadores vêm ainda indicados por outro sinónimo, neaniskoi (Them. 1.3, Cim. 16. 5, Arat. 6. 4).

Também a palestra (lugar vocacionado, como sugere o próprio nome, para o treino da 'luta'gr. pale) tinha por público alvo os indivíduos que ainda não haviam atingido a maturidade, i. e., os 'meninos' (paides: Alc. 3. 1, Eum. 1-2), os 'adolescentes' (meirakioi: Cat. Ma. 3. 628, Eum. 1-2) e os 'jovens' - neoi (Alc. 17. 4, Pel. 19. 1, Nic. 12. 1) e neaniskoi (Arat. 6. 4). Depreende-se ainda que a modalidade de combate

${ }^{26}$ Cf. supra, a propósito de Dem. 4. 4, Arat. 3. 1 e Eum. 1.1.

27 Sobre as funcionalidades e arquitectura destes espaços, vd. Roland (1974: 217-220, 275-281). Impóe-se, desde já, um esclarecimento: os pórticos eram galerias que integravam a arquitectura das palestras e dos ginásios, permitindo a prática de exercício físico a resguardo das agressóes do sol ou da chuva.

${ }^{28}$ Neste passo Plutarco, pela boca de Catão Censor, classifica de passatempos 'próprios de adolescentes' (adjectivo meirakiodes), as idas de Cipião às palestras e aos teatros. 
exercitado poderia variar de acordo com o "escalão" do praticante, pois, como se lê no referido trecho da Vida de Eumenes (1-2): 'conta o historiador Dúris que...quando (Êmenes) ainda era um menino, Filipe, dispondo de tempo livre na sua passagem pela cidade de Cárdia, pôs-se a observar os adolescentes a exercitaremse no pancrácio e os meninos na luta'. Como se sabe, o combate mais violento, permitindo quase todo o tipo de golpes (à excepção dos desferidos contra os olhos e das dentadas), devia a sua designação precisamente ao título 'todo poderoso' (pankration) aplicado ao deus supremo do panteão grego, Zeus. Daí que se exigisse aos seus praticantes um elevado vigor físico, prematuro na infância. Nesta idade, o treino no combate corpo a corpo iniciava-se, pois, através de exercícios menos exigentes e sem tantos riscos de lesão (a pale).

Ainda no âmbito das valências físicas desenvolvidas na palestra e no ginásio, compreende-se que uma categoria específica de profissionais frequentasse tais espaços, os atletas (justamente denominados 'os da palestra', oi $\pi \varepsilon \rho i$ $\pi \alpha \lambda \alpha i ́ \sigma \tau \rho \alpha v$, cf. Galb. 16. 2), tanto os já galardoados em diversos concursos desportivos afamados (Demetr. 5. 3), como os que aspiravam atingir tão prestigiada distinção (Arat. 3. 1). Estes dois últimos passos testemunham também aquela que era a prática adoptada nos concursos desportivos de distinguir dois escalóes, um de jovens outro de adultos. Na biografia de Arato, Plutarco reportase ao período da sua juventude (ou, como se lê no texto: 'educado em Argos, entre hóspedes e amigos paternos, segundo o padrão liberal, ao dar conta de que o seu 
corpo aumentava de vigor e tamanho, aplicou-se aos exercícios da palestra, de modo que veio a concorrer no pentatlo e a receber coroas da vitória'). Já na de Demétrio, o autor conta que este, com os seus vinte e dois anos, ao ser enviado por seu pai, Antígono da Macedónia, contra Ptolomeu, só podia ser comparado a um jovem (neos) inexperiente diante de um adulto (aner), 'vindo da palestra de Alexandre, um atleta que, à sua conta, disputara já muitos e importantes concursos'.

Porque reúnem a flor da juventude grega e/ou helenizada, os ginásios e as palestras, espaços naturalmente propensos à sociabilização do indivíduo do sexo masculino e de condição livre, são locais frequentados por duas categorias de pessoas bem individualizadas por Plutarco, os 'mais velhos' (presbyteroi) e os 'amantes' (erastai), dois grupos referenciais na educação do futuro adulto. Moralmente avesso ao amor homoerótico, o biógraforelata, como vimos atrás, várias histórias trágicas de tentativas de homens maduros que envidam esforços para concretizar um relacionamento sexual com um parceiro jovem, que, no entanto, os repudia ${ }^{29}$. Os locais escolhidos para o assédio são precisamente esses dois,

${ }^{29}$ Sobre a temática do homoerotismo, em particular, vd. Stadter 1995, Walcot 1998, Beck 2007. Os relacionamentos pederásticos constituem uma realidade distinta da anterior e, porque legítima e culturalmente aceite no mundo grego e romano helenizado, apenas surge abertamente censurada pelo nosso autor, quando revestida de contornos de violência (caso dos abusos referidos nas vidas de Demétrio e Címon, como vimos anteriormente). Para um balanço sobre a questão da pederastia na obra de Plutarco, vd. D' Ippolito 2007. 
como se lê a propósito do pretendido de Demétrio, 'que

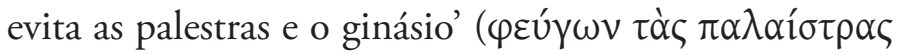

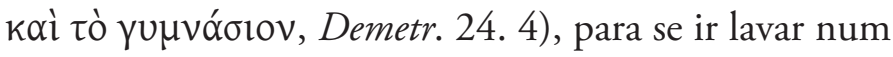
balneário privado ${ }^{30}$, de modo a escapar às investidas amorosas indesejadas. Ainda que náo revestido do tom recriminatório contido nos passos em que se desenha um cenário de violação, o relato da introdução, no código de leis dos Tebanos, da música de flauta no ambiente das palestras contém uma velada censura ( Pel. 19. 1). Na verdade, quando se acrescenta que tal medida surtiu o efeito de amolecer o carácter dos jovens, ficando implícita a perda de virilidade, a responsabilidade desse enfraquecimento vem atribuída ao estímulo da música para os relacionamentos amorosos.

Já no que se refere aos anciáos, estes constituem para os jovens uma fonte de informaçáo, seja ela sobre

${ }^{30}$ Os exercícios físicos eram realizados sob um solo coberto de areia, prática confirmada na Vida de Alexandre (40. 1), onde se refere o luxo extravagante do seu companheiro Leonato, que fazia vir do Egipto camelos carregados de areia. Se lembrarmos que, antes de se exercitarem, os atletas untavam os corpos com azeite (cf. Cim. 16. 5), da conjugaçáo destes dois elementos, a que acresce o suor decorrente do esforço, resulta natural que dos ginásios e das palestras os jovens se dirigissem para os balneários - fossem eles privados, como é o caso referido supra, ou públicos (as termas dos Romanos, cf. Marc. 27. 3). A avaliar pelos achados arqueológicos encontrados em algumas das salas anexas ao pátio central destinado aos exercícios de luta (a "palestra" propriamente dita) o complexo arquitectónico dos ginásios incluía já, além dos indispensáveis vestiários, balneários (para banhos que podiam ser de água fria ou quente, bem como de vapor). Sobre a arquitectura dos espaços destinados à prática do exercício físico, vd. Roland (1974: 275281). 
a vida política contemporânea ou sobre outra qualquer matéria de interesse. Aliás, Plutarco sintetiza bem na equivalência que estabelece entre estes e a figura paterna a função tutelar que, à luz da educação grega e romana antiga, um indivíduo de idade avançada exercia perante um jovem em formação. Como se lê em Lyc. 17. 1: 'Era

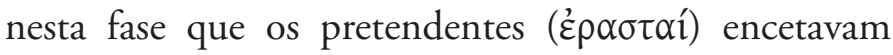
relaçóes com os jovens educados e que os mais velhos (oi $\pi \rho \varepsilon \sigma \beta u ́ \tau \varepsilon \rho o 1)$ se encarregavam deles, passando a frequentar com mais regularidade os ginásios, de modo a vigiarem-nos não só quando competiam, mas também quando brincavam, náo de forma displicente, mas com tal empenho que muitos os consideravam autênticos pais, pedagogos ou mestres'. A ideia de que a ocupação digna dos anciãos espartanos é esta (e não andar às compras na ágora), reaparece mais adiante na mesma biografia (Lyc. 25. 2).

São também 'os mais velhos' que, com os seus relatos empolgantes sobre os projectos de uma expedição naval à Sicília, ajudam a cativar o entusiasmo dos jovens pela estratégia agressiva do arrojado Alcibíades (Alc. 14. $4)^{31}$. Que essa é uma mensagem que começa a expandirse entre os Atenienses, atesta-o o facto de, no terreiro das palestras e dos hemiciclos, se começarem a ver desenhados mapas da ilha (ibidem). Aliás, a identificação

${ }^{31}$ A confirmação de que os ginásios, pelo público que reúnem, são locais eleitos também pelos líderes para angariarem apoios políticos e/ou armados para as suas causas encontramo-la, e.g., em Pel. 7. 5 . 
de determinado local como "propriedade" de uma faixa etária, é um elemento que recorre em Plutarco a propósito deste confronto jovens/velhos. Se as palestras e os ginásios são o território natural de quem ainda possui vigor físico para se entregar quotidianamente à prática desportiva, os lugares em que a motivação para o convívio é sobretudo conversar (como os pórticos, as lojas/oficinas e outros locais de reunião - pela sua forma geométrica, apelidados de 'hemiciclos') merecem a preferência dos mais velhos. Esta distinção evidenciase bem nos seguintes trechos: Nic. 12. 1 (onde se retoma a história da difusão da estratégia de Alcibíades, com a menção expressa de que 'os jovens, nas palestras, e os velhos, sentados nos ateliers e nos hemiciclos, desenhavam o mapa da Sicília...') e Cat. Ma. 3. 6 (onde se dá conta das censuras feitas pelo Censor a Cipião, acusado de se entregar ao ócio dos adolescentes, por gastar o seu tempo em palestras e teatros). 


\section{Observaçóes Finais}

A análise a que sujeitámos os retratos de crianças e jovens das Vidas permite-nos identificar aqueles que consideramos os resultados mais significativos da nossa investigaçáo, que passamos a apresentar.

1. $\mathrm{Na}$ existência do ser humano podem individualizar-se três etapas principais: a idade adulta (a mais relevante em termos biográficos), a que a antecede e a velhice. Na verdade, não obstante a panóplia de termos de que dispunha para designar crianças (brephos, nepios, paidion, paidarion e pais) e jovens (antipais, meirakion, neos, neanias, neaniskos e ephebos), Plutarco, no tratamento que dá a essas numerosas "sub-etapas", revela considerá-las sobretudo um todo, bem individualizado da idade adulta, mais do que uma construçáo baseada em realidades com fronteiras claramente distintas. Daí que nos tenhamos sentido autorizados a não enveredar por uma reflexão em separado da caracterização física e psicológica dos indivíduos, bem como da educação que os molda, primeiro para a infância e posteriormente para a juventude.

2. É sobretudo na infância e juventude, períodos de definição da identidade do sujeito, que se definem as figuras que, ao longo da sua vida, sobre ele hão-de exercer a função de modelos e/ou referências tutelares. $\mathrm{O}$ afecto, natural entre progenitores e filhos, funciona como veículo 
para estabelecer uma ligação emocional estruturante no período de formação do carácter do indivíduo. Permitimo-nos recordar dois exemplos em particular, uma vez que ambos apelam ao afecto dos pais pelos seus descendentes quando estes são de tenra idade, ou seja, quando se encontram na fase em que tradicionalmente se considera caber às mães o predomínio das manifestaçóes de 'amor à prole' (philostorgia ou philostorgon) ${ }^{1}$. Um dos gestos mais ternurentos é a participação de Catão no banho do seu recém-nascido (Cat. Ma. 20. 4), atitude que parece coadunar-se pouco ao cognome Censor, que lhe viria a ser atribuído devido à sua actuação implacável na magistratura em questão. Ainda dentro desta linha, lembremos o entusiasmo com que o rei espartano, Agesilau, se junta aos seus pequenotes numa cavalgada de faz de conta (Ages. 25. 11) ${ }^{2}$.

Para além dos laços de sangue, a relação próxima e o convívio (quase) diário da criança e/ou do jovem

${ }^{1}$ Embora seja extemporâneo tratar aqui demoradamente esta questão na produção literária de Plutarco, não poderemos deixar de remeter para um tratado exclusivamente dedicado ao afecto pelos filhos, na designação latina: De amore prolis, já disponível em tradução portuguesa (Soares 2010).

${ }^{2}$ Embora não seja este o local apropriado para tratar um tema que já tanta tinta tem feito correr entre os estudiosos, não podemos deixar de recordar que nem todos os bebés eram bem vindos. Vimo-lo para a prática espartana de eliminar os mais fracos ( $L y c$. 16. 2), recordo ainda a lenda dos gémeos Rómulo e Remo, lançados ao rio e inicialmente salvos pelo aleitamento de uma loba (Rom. 2-4). Sobre a prática da 'exposiçáo' (ekthesis) dos infantes, vejam-se os seguintes títulos: Patterson: 1985; Golden: 1990: 86-87; Harris 1994; Rawson 2003: 117-119. 
com outros adultos responsáveis pela sua educação afiguram-se contextos propícios a desenvolver no formando uma admiração (que pode ser acompanhada de afecto) por tais figuras tutelares. Vejamos três casos paradigmáticos desta situação. Até certa altura da sua vida, Alexandre tinham com o filósofo Aristóteles um entendimento e uma harmonia de tal forma intensos que Plutarco escreve: 'no início, como ele dizia, a sua

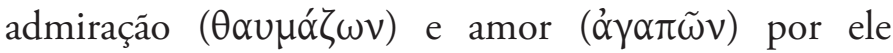
não era menor (oủx $\tilde{\eta} \tau \tau o v$ ) do que a que sentia pelo pai, uma vez que um lhe dera a vida, ao passo que com o outro aprendera uma vida virtuosa' ( $\kappa \alpha \lambda \tilde{\omega} \varsigma$ $\zeta \tilde{\omega} v$, Alex. 8. 4). Ainda que possa ser movido por intuitos de bajulação (o que Plutarco neste ponto concreto não refere), Augusto, meirakion ambicioso e precocemente coberto de poderes, graças à intervenção de Cícero, retribuiu o apreço manifestado pelo mentor, chamando-o de pai (Cic. 45.2). Para último guardámos o episódio que retrata a rivalidade que poderia existir entre progenitores e educadores pela preferência de uma criança. É o desejo de evitar afectos ou 'dívidas de

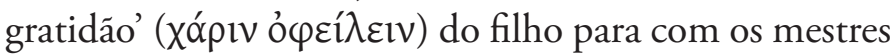
escravos - retribuiçóes que quereria apenas para si (Cat. Ma. 20. 6) - que leva Catáo Censor a encarregar-se pessoalmente da educação do menino na infância.

3. Os retratos de crianças e jovens delineados nas Vidas continuam, volvidos cerca de dezanove séculos sobre a sua redacção e salvas as diferenças decorrentes dos particularismos próprios de cada circunstância, a parecer familiares ao leitor contemporâneo. No geral, 
não despertam nele uma sensação de "estranhamento", mas sim de "reconhecimento".

Vemos, assim, uma vez mais confirmada a justeza de incluir Plutarco entre os grandes clássicos do pensamento universal. 


\section{BibLIOGRAFia}

\section{Ediçóes, traduçóes e comentários}

Flacelière, R, chambry, E. (1957-79), Plutarque. Vies. Paris. Les Belles Lettres. 15 vols.

Ziegler, K. (1959-2002), Plutarchi Vitae Parallelae. Leipzig. Teubner.

Perrin B. (1967-75), Plutarch's Lives. Harvard University Press. Loeb Classical Library. 11 vols. $2^{a}$ ed. iniciada em 1994.

Waterfield, R. (transl.) and Stadter, Ph. (introd. and notes) (1998), Plutarch. Greek Lives: a Selection of Nine Greek Lives. Oxford.

(1999), Plutarch. Roman Lives: a Selection of Eight Roman Lives. Oxford.

Hartog, F. (coord.) (2001), Plutarque. Vies parallèles. Traduction d' Anne-Marie Ozanam. Édition annotée par Claude Mossé, Jean-Marie Pailler et Robert Sablayrolles. Paris.

Pérez Jiménez, A. (2007-2009), Plutarco. Vidas paralelas. Madrid. Editorial Gredos.

Leâo, D., Fialho, M. C. (2008), Plutarco. Vidas Paralelas: Teseu e Rómulo. Centro de Estudos Clássicos e Humanísticos. Coimbra. 
Pinheiro, J. (2008), Plutarco, Da educação das crianças. Tradução do grego, introdução e notas. Centro de Estudos Clássicos e Humanísticos. Coimbra.

Ferreira, A., Rodrigues, A. (2010), Plutarco. Vidas Paralelas: Péricles e Fábio Máximo. Tradução do grego, introdução e notas. Centro de Estudos Clássicos e Humanísticos. Coimbra.

Fialho, M. C, Rodrigues, N. S. (2010), Plutarco. Vidas Paralelas: Alcibiades e Coriolano. Tradução do grego, introdução e notas. Centro de Estudos Clássicos e Humanísticos. Coimbra.

Soares, C., Rocha, R. (2010), Plutarco. Obras Morais. Sobre o Afecto aos Filhos. Sobre a Música. Tradução do grego, introdução e notas. Centro de Estudos Clássicos e Humanísticos. Coimbra.

Várzeas, M. (2010), Plutarco. Vidas Paralelas: Demóstenes e Cícero. Tradução do grego, introdução e notas. Centro de Estudos Clássicos e Humanísticos. Coimbra.

\section{Estudos}

Anderson, J. K. (1985), Hunting in the Greek World. London.

Arnett, J. J. (2004), Emerging Adulthood: The Winding Road from the Late Teens trough the Twenties. Oxford. 
Beck, M. (2007), "Eroticism, Power, and Politics in the Parallel Lives", in Nieto Ibañez, J. M., López López, R. (eds.), El Amor en Plutarco. Universidad de León, Secretariado de Publicaciones (León), 457-466.

Belfiore, E. S. (2000), Murder Among Friends. Violation of Philia in Greek Tragedy. New York, Oxford, cap. 1: "Philia Relationships and Greek Literature", 3-20.

Blundell, M. W. (1989), Helping Friends and Harming Enemies. A Study in Sophocles and Greek Ethics. Cambridge.

Bradley, K. (1999), "Images of Childhood : The Evidence of Plutarch', in Pomeroy, S. (ed.), Plutarch's Advice to the Bride and Groom and A Consolatio to his Wife. Oxford, 183-196.

Castellani, V. (2002), 'Plutarch's 'Roman' Women', in Ostenfeld, E. N. (ed.), Greek Romans and Roman Greeks. Aarhus, 142-155.

Cohen, A. and Rutter, J. B. (2007), Constructions of Childhood in Ancient Greece and Italy [Hesperia Supplement 41].

Corbier, M. (2001), "Child exposure and abandonement", in Dixon, S. (ed.), The Roman Family. Baltimore, 52-73.

D’ ippolito, G. (2007), “Omosessualità e pederastia in Plutarco”, in Nieto Ibañez, J. M., López López, R. 
(eds.), El Amor en Plutarco. Universidad de León, Secretariado de Publicaciones (León), 467-476.

Duff, T. (2003), "Plutarch on the Childhood of Alkibiades (ALK. 2-3)”, PCPhS 49: 89-117.

Eyben, E. (1981), "Was the Roman "Youth" an "Adult" Socially?”, $A C$ 50. 1-2: 328-350.

(1996) “Children in Plutarch", in Van der Stockt, L. (ed.), A Miscellany of Plutarchea Lovaniensia. Essays on Plutarch, [Studia Hellenistica 20]. Lovanii, 79-112.

FACQ, F. (2004/05) ,'L' attitude des adults vis-à-vis des enfants pendants les guerres, chez Plutarque", Ploutarchos n. s. 2: 41-54.

Ferrary, J.-L. (1988), Philhellénisme et impérialisme: aspects idéologiques de la conquête romaine $d u$ monde hellénistique. Rome.

Ferreira, L. N. (2010), “A criança na Grécia Antiga: concepçóes, normas e representaçóes", in Fonseca, A. C. (ed.), Crianças e adolescentes. Uma abordagem multidisciplinar. Almedina. Coimbra.

Golden, M. (1990), Children and Childhood in Classical Athens. Baltimore and London.

Green, C. M. C. (1996), "Did the Romans Hunt?", ClAnt 15. 2 : 222-260.

Grimal, P. (1975), Le siècle des Scipions: Rome et 
l'hellénisme au temps des guerres puniques. (2. éd. refondue et augm.), Aubier, 1975.

(1992), Dicionário da mitologia grega e romana. Trad. de V. Jabouille. Lisboa.

Gruen, E. S. (1992), Culture and National Identity in Republican Rome. Ithaca, New York, ch. 2: "Cato and Hellenism", 52-83.

Haentjens, A. M. F. (2000), "Reflexions on Female Infanticide in the Greco-Roman World", $A C$ 69: 261-264.

Harlow, M. and Laurence, R. (2002), Growing up and Growing old in Ancient Rome. A Life Approach. London, New York.

Harris, W. V. (1994), "Child Exposure in the Roman Empire”, JRS 84: 1-22.

Henrichs, A. (1995), “Graecia capta: Roman Views of Greek Culture”, HSCPh 97: 243-261.

Hubbard, Th. K. (2006), 'History's First Child Molester: Euripides' Chrysippus and the Marginalization of Pederasty in Athenian Democratic Discourse', in Davidson, J. et alii (ed.), Greek Drama III. Essays in Honour of Kevin Lee. London, 223-244.

Huys, M. (1996), 'The Spartan Practice of Selective Infanticide and its Parallels in Ancient Utopian Tradition', Ancient Society 27: 47-74. 
Hyland, A. (2003), The Horse in the Ancient World. Stroud.

Ingals, W. B. (2002), "Demography and Dowries: Perspectives on Female Infanticide in Classical Greece", Phoenix 56: 246-254.

Johnston, S. I. (2001), “Charming Children: the Child in Ancient Divination”, Arethusa 34: 97-117.

Kennell, N. M. (1995), The Gymnasium of Virtue. Education \& Culture in Ancient Sparta. Chapel Hill, London.

Konstan, D. (1997), Friendship in the Classical World. Key Themes in Ancient History. Cambridge.

Lear, A. and Cantarella, E. (2008), Images of Ancient Greek Pederasty. Boys Were their Gods. London, New York.

Le Corsu, F. (1981), Plutarque et les femmes dans les Vies parallèles. Paris.

Marrou., H. (1965), Histoire de l'éducation dans l' Antiquité. Paris.

Mcinerney, J. (2003), "Plutarch's Manly Women", in Rosen, R. M. and Sluiter, I. (eds.), Andreia: Studies in Manliness and Courage in Classical Antiquity [Mnemosyne Supplement 238]. Leiden and Boston, 319-344.

Nikolaidis, A. (1997), "Plutarch on Women and Marriage”, WS 110: 27-87. 
(ed.) (2008 a), The Unity of Plutarch's Work [Millenium Studies 19]. Berlin, New York.

(2008 b), “7. Women, Eros, Marriage, and Parenthood in Plutarch", in Nikolaidis, A. (ed.), The Unity of Plutarch's Work [Millenium Studies 19]. Berlin, New York, 657-727.

Oliveira, F. (1973-74), "O conceito de $\varphi \imath \lambda i ́ \alpha$ de Homero a Aristóteles", Humanitas 25-26: $217-$ 235.

Patterson, C. (1985), “'Not Worth the Rearing': the Causes of Infant Exposure in Ancient Greece”, TAPhA 115: 103-123.

Pelling, Ch. (1990), "Childhood and Personality in Greek Biography”, in Pelling, Ch. (ed.), Characterization and Individuality in Greek Literature. Oxford., 213-244.

Rawson, B. (2003), Children and Childhood in Roman Italy. Oxford.

Roland, M. (1974), L'urbanisme dans la Grèce antique. Second édition augmentée. Paris.

Russel, P. (1943), "L'exposition des enfants à Sparte”, REA 45: 5-17.

Scoтt, M. (1982), "Philos, philotês and xenia", AC 25 : 1-19.

Skinner, M. B. (2005), Sexuality in Greek and Roman Culture. Malden, Oxford. 
Soares, C. (2004), "Os laços de família em Plutarco: Consolatio ad uxorem (Moralia $608 \mathrm{C}$ )", Buletim de Estudos Clássicos 42 (Dezembro) 39-44.

(2005), "Os laços de família em Plutarco: Vita Solonis (VII. 5-6)", Buletim de Estudos Clássicos 44 (2005) 67-71.

(2006 a), "Os laços de família em Plutarco: Vita Coriolani (IV. 3-4)”, Buletim de Estudos Clássicos 45 (Junho) 31-34.

(2006 b), "Os laços de família em Plutarco: De amore prolis (495 a-b) - comparação entre animais racionais e irracionais", Buletim de Estudos Clássicos 46 (Dezembro) 23-27.

(2007 a), "Os laços de família em Plutarco: De amore prolis (495 B-C) - definição da essência do ser humano", Buletim de Estudos Clássicos 47 (Junho) 23-27.

(2007 b), "Referencias al amor paterno en Plutarco", in Nieto Ibañez, J. M., López López, R. (eds.), El Amor en Plutarco. Universidad de León, Secretariado de Publicaciones (León) 591597.

(2007 c), "Os laços de família em Plutarco: De amore prolis (496 A-C) - o amor materno", Buletim de Estudos Clássicos 48 (2007) 37-41.

(2008), "Parent-child Affection and Social Relationships in Plutarch: Common Elements in 
Consolatio ad uxorem and Vitae', in Nikolaidis, A. (ed.), The Unity of Plutarch's Work [Millenium Studies 19]. Berlin, New York, 719-727.

- (2009), "Os laços de família em Plutarco: De amore prolis (496 C-E) - o amor materno (II)", Buletim de Estudos Clássicos 51 (Junho) 21-24.

Stadter, Ph. A. (1995), "Subject to the Erotic: Male Sexual Behavior in Plutarch", in Innes, D. C., Hine, H. M. and Pelling, C. B. R. (eds.), Ethics and Rhetoric: Classical Essays for Donald Russell on his Seventy-Fifth Birthday. Oxford, 221-236.

(1999), "Philosophos kai Philandros: Plutarch's View of Women in the Moralia and Lives", in Pomeroy, S. (ed.), Plutarch's Advice to the Bride and Groom and A Consolatio to his Wife. Oxford, 173-182.

Walcot, P. (1998), "Plutarch on Sex", G\&R 45: 166-187.

(1999), "Plutarch on Women", Symbolae Osloenses 74: 163-183.

Williams, C. A. (1999), Roman Homosexuality. Ideologies of Masculinity in Classical Antiquity. Oxford.

Younger, J. G. (2005), Sex in the Ancient World from A to $Z$. London. 


\section{ÍNDICE ONOMÁSTICO}

\section{Autores Modernos}

Arnett: 14 n. 1

BECK: 104 n. 29

BELFIORE: 95 n. 23

BLUNDELL: 95 n. 23

Bradley: 51

Castellani: $26 \mathrm{n} .9$

Cohen: 28 n. 10

Corbier: 31 n. 2

D' Ippolito: 34 n. 4, 104 n. 29

Eyben: 13, 21 bis, 54

FERrary: 76 n. 10

FERREIRA: 13

Golden: 13, 18 n. 2, 26 n. 9, 33

n. $3,46,51,52$ bis, 86 n. 18 , 110 n. 2

GreEn: 79 ter

GRIMAL: 76 n. 10, 84 n. 16

GRUEN: 76 n. 10

Haentjens: 31 n. 2

Harlow and Laurence: 13, $21 \mathrm{n}$. 6, 52, 53 n. 3

HARris: 31 n. 2, 110 n. 2

HENRICHS: 76 n. 10

HubBard: 34

Huys: 31 n. 2

HyLAND: 79 n. 13

INGALS: $31 \mathrm{n} .2$

JOHNSTON: 53 n. 3

Kennell: 65, 66 n. 3, 67, 67 n.4, 69 n. 5

KONSTAN: 95 n. 23
Lear and Cantarella: 34 n. 4

Le Corsu: 26 n. 9

Liddell and Scott: 9

Marrou: 75,76 n. 10,78 bis, $84 \mathrm{n}$.

17,86 n. 18

MCINERneY: $26 \mathrm{n} .9$

Nikolaidis: 8 n. 3, 26 n. 9

Oliveira: 95 n. 23

Patterson: 31 n. 2,110 n. 2

Pelling: 28

Pinheiro: 8 n. 2

Rawson: 13, 20, 86 n. 18, 100, 110 n. 2

RoLAND: 102 n. 27,105 n. 30

RUSSEL: 31 n. 2

Sсотт: 95 n. 23

SKINNER: 34 n. 4

SoARES: 7,7 n. 1,8 n. 2,110 n. 1

Stadter: 26 n. 9, 57 n. 4, 65, 66 n.

3, 71 n. 6,72 n. 7,104 n. 29

Walcot: 26 n. 9, 104 n. 29

Williams: $34 \mathrm{n} .4$

YOUNGER: 34 n. 4

Ziegler: 9 


\section{Antropónimos}

Acrótato: 35

Agesilau: 17, 31 n.2, 32, 88, 110

Ágis: 58

Alcandro: 60

Alcibíades: 19, 32, 87, 94, 98, 106, 107

Álcio: 77 n. 11

Alexandre: 20, 36, 37, 43, $46 \mathrm{n}$. 2, 50, 59 bis, 63 n. 1, 73 bis, $83,85,91$ n. 21 bis, 96 bis, $98,99,111$

Anaxágoras: 80 n. 14

Aníbal: 18

Antífates: 33

Antígono da Macedónia: 23, 55, 91 n. $21,94,104$

Antilo: 20 n. 4, 20 n. 5, 97

Antíoco: 89

Antípatro: 46 n. 2

Aquiles: 50, 99

Arato: $23,43,44,55,58$ bis, 75 bis

Ariárates: 90

Árifron: 94

Aristides: 34

Aristóteles: 63 n. 1, 85, 100, 111

Arquíloco: 45

Árron: 97 bis

Augusto: 20, 21 bis, 22 bis, 43, 86,111

Bruto: 47, 53, 56, 85

Cábrias: 18, 56 bis, 96

Calíope: 84 n. 16

Capitolino: 34

Carnéades: 24, 49

Cássio: 45

Catão Censor: 15, 16, 22, $22 \mathrm{n}$. $7,53,54,63,74,75$ bis, 76 bis, 77 bis, 77 n. $11,78,81$ n. $15,83,85,88,91,92 \mathrm{n}$. 22, 102 n. $28,107,110,111$ Catáo de Útica: 45, 56, 60, 89 n. 20, 94

Catilina: 42

Cesarião: 20 n. 4, 20 n. 5, 24, 96

Cícero: 42, 43, 46, 50, 54, $77 \mathrm{n}$. $11,82,86$ bis, 111

Címon: 42, 44, 104 n. 29

Cipiāo Africano: 76 n. 10

Cipião Emiliano: 54, 58, 76 n. 10, 102 n. 28,107

Cleómenes: 23, 33, 67 n. 4

Cleónimo: 32

Cleópatra: 20 n. 4, 96

Clio: 84 n. 16

Clódio:37, 38

Coriolano: 54, 83 bis, 87, 91, 93

Cornélia: 87 bis

Cratipo: 77 n. 11

Ctesipo: 18, 56 bis, 96

Cúrio: 43

Dâmocles: 36

Demétrio: 23, 36, 54, 55 bis, 91 n. 21, 94, 104 n. 29,105

Demófanes: 21,80

Demóstenes: 36 bis, 77, 82, 90, $92,93,100$

Diógenes: 24

Díon: 53

Dionísio: 44, 53

Dioniso: 15, 35, 87 n. 19

Ecdelo: 21, 80

Emílio Paulo: 32, 54 ter, 56, 76, 76 n. $10,77,79,79$ n. 13,81 n. 15,88 
Epaminondas: 93

Érato: 84 n. 16

Ésquines: 90

Estesilau: 34

Estratonice: 90

Êmenes: 96 ter

Euterpe: 84 n. 16

Fábio Máximo: 22 n. 7, 54, 5657

Fénix: 99

Filipe II: 43, 59, 83, 85, 90, 96, 100

Filipe V: 91 n. 21

Filisco: 77 n. 2

Fílon: 82

Filopémen: 22, 57 n. 4, 80, 81 n. $15,82,83,96$

Fócion: 44, 46 bis, 55, 56, 59, 67, 96, 101

Fúlvia: 20 n. 4, 97

Gaio Lúsio: 33

Górgias: 42

Heitor: 50

Juba: 73

Ísidas: 18

Isócrates: 93, 100

Júlio César: 15, 20 n. 4, 35, 48, 57 n. 4,81 n. 15,96

Leonato: 105 n. 30

Leónidas: 94, 95, 98 bis

Leóstenes: 46, 59

Licurgo: 16, 60, 64, 67 n. 4, 72, 94 ter, 95 ter, 98

Lisímaco: 99, 100

Lívio Druso: 94

Luculo: 42

M. Fúlvio Flaco:33

Marcelo: 34, 49

Marco António: 20 n. 4, 20 n. 5, $42,85,97$

Mário: 33, 35, 57
Metelo: 50, 58

Melpómene: 84 n. 16

Mitridates: 90

Múcio Sévola: 82

Nícias: 35

Nícocles: 43

Nicógenes: 100

Numitor: 41

Olímpia: 43, 96

Panteu: 33

Peleu: 99

Pelópidas: 32,48

Péricles: 80 n. 14, 94

Perseu: 53, 57, 63 n. 4, 78 n. 12

Pirro: $15,54,83$

Platáo: 53, 101

Polidectes: 14,16

Polímnia: 84 n. 16

Pompeio: 15, 23, 35, 54, 56, 57 bis, 57 n. 4 ter, 58 bis, 58 n. 5,85

Ptolomeu: 23, 55, 56, 104

Rea: 87

Remo: 14, 16, 33, 41 bis, 110 n. 2

Rómulo: 14, 16, 41, 110 n. 2

Seleuco: 89, 90

Sertório: 73, 74, 82, 85

Sicino: 100

Sólon: 37

Sula: $21,44,45,54,57,57$ n. 4, 58,82

Talia: 84 n. 16

Temístocles: 33, 34, 59, 92 n. 22, 100

Terpsícore: 84 n. 16

Tucídides: 77

Tarquínio: 54

Teseu: 37, 97

Urânia: 84 n. 16

Volúmnia: 87

Xenócrates: 101 
Xerxes: 100

Zenão: 80 n. 14

Zeus: 103

Zópiro: 98 


\section{EtNónimos}

Aqueus: 57 n. 4

Atenienses: 37, 46, 59, 92 n. 22

bis, 101, 106

Beócios: 46 n. 2

Cartagineses: 18 bis, 58

Espartanos: 31, 33 n. 3, 36, 65,

57 n. 4 bis, 70, 95, 98

Etruscos: 79

Gauleses: 18, 48

Gregos: 50, 58, 59, 64, 65, 73, 79, 82, 84, 86 n. 19, 92 n.

22, 96, 97, 98 bis

Iberos: 74

Lacedemónios: 71

Latinos: 79, 82

Macedónios: 46 n. 2

Molossos: 67

Romanos: $64,73,76,77$ bis, 82 bis, 86,87 n. 19,89 n. 20 , 97, 98,105 n. 30

Sabinas: 15

Tebanos: 18, 59, 105

Tessálios: 46 n. 2

Vilanovenses: 79 


\section{Topónimos}

Alexandria: 20 n. 5

Argos: 43

Atenas: 48, 59, 77 n. 11, 82, 85

Ática: 36 n. 5

Beócia: 46

Bizâncio: 59

Cartago: 54

Corinto: 58

Egipto: 20 n. 5, 105 n. 30

Eólia: 100

Esparta: 67 ter, 95

Farsália: 35

Gália: 58

Gaza: 55

Grécia: 74, 75, 77 n. 2, 79 n.

13,86

Lacónia: 14

Lâmias: 46 n. 2

Lícia: 47

Macedónia: 96

Numância: 54

Numídia: 35

Pireu: 46 n. 2

Queroneia: 59

Roma: 24, 56, 58, 75, 76, 83, 85

Salamina: 100

Sicília: 18, 44, 47, 106, 107

Sícion: 43,55

Siracusa: 53

Trezena: 101

Tarento: 22 n. 5

Xanto: 47 


\section{ÍNDICE DAS VIDAS}

Aem.

6. 8: 73, 77,

6. 8-10: 101

6. 9: 77,79

6. $10: 88$

8. 9: 91

10. $6: 16$

10. 7-8: 51

10. $8: 53$

15. $4: 57$

17. $3: 25$

17. $4: 54$

22. $4: 21,54$

22. $8: 55$

27. 1: 54

28. $11: 78$

33. 6: 16, 24, 63 n. 1

39. $8: 23,32$

Ages.

2. $3: 31$ n. 2

3. $1: 17$

11. $2: 33$

20. $9: 33$ n. 3

25. $1: 32$

25. 11: $16,88,110$

34. 9: 18

Agis

3. 8: 95

4. 2: 49

6. 1-2: 23

14: 58

14. $3: 58$

Alc.

1. 2: 94

1. $4: 19,22,32$
3. 1: 102

7. $1: 25$

14. 4: 106 bis

17. 4: 102

18. $8: 45$

Alex.

1. 2: 27

5. 7: 63 n. 1,98 bis

5. 8: 99

8. $2: 50$

8. 4: 111

7. $1: 84$

7. $2: 84,85,100$

9. $1: 59$

9. $2: 59$

10. $6: 43$

11. $6: 19,20$

22: 98

22. $1: 35$

24. 11: 99

25: 98

25. 6-8: 99

35. $6: 36$

40. 1: 105 n. 30

47. 6: 74

48. 5: 59

53. $1: 23$

71. 1: 37, 64

72. $2: 37$

Ant.

2. $4: 43$

2. $7: 86$

71. 3: 20 n. 4 e n. 5, 24

81. $2: 97$

81. 4: 96 
Arat.

3. 1: 75, 102 n. 26, 103 bis-104

5. 2: 55

6.4: 43

6. 4-5: 24, 102 bis

36. $5: 23$

53. 6: 24

Arist.

2. 2-4: 34

2. $4: 32$

Brut.

3. 3: 56

9. 1-2: 45

24. 2: 86

27. 3: $21,22,43$

31. $4: 16,47$

31. $5: 16$

40. 7: 53

$C G$

16. 1: 33

16. 1-2: $24+$

Caes.

10. 1: 37

10. 3: 38

17. $6: 81$

18. $4: 48$

23. $6: 15$

45. 3: 23

45. 3-4: 35

55. 3: 73

56. 1: 57 n. 4

56. 2: 57

56. 3: 52
Cam.

15. 3-4: 24

15. 4-6: 97

21. $1: 15$

Cat. Ma.

1. 8: 22,53

2. 3: 22,54

2. 5: 77

3. $6: 102,107$

8. 4: 92 n. 22

8. 5: 92 n. 22

17. $2: 25$

20: 85,87 n. 19,101

20. 1: 52,88

20. 3: 52

20. $4: 15$

20. 5: 16, 74, 91

20. 6: $74,76,85,111$

20. 7: 74, 75

20. 9: 63

20. 10: 54,76

21. 1: 63

22. 2-3: 24

22. 3: 49

22. $4: 24$

22. $5: 76$

22. 5-7: 77 n. 11

22. $7: 76$

23. $1: 76$

23. 22: 77

Cat. Mi.

1. 2: 94

1. 3: 41,60

1. $9: 43$

1. $10: 84,99$

2. $6: 89$ n. 20

3: 51

3. 1: 81

3. $8: 17$ 
7: 45

13. $1: 24$

Cic.

2. 3: 50

3. $1: 82$

3. $2: 54$

6. $2: 47$

7. $7: 21$

10. $4: 25,42$

22. $2: 46$

24. $7: 77$

24. $8: 42$

26. $7: 90$

28. $2: 37$

28. $3: 38$

40. $1: 86$

44. $1: 86$

44. 5: 75

45. 1-2: 22

45. 2: 111

46. $1: 23$

46. $2: 23$

Cim.

1. $2: 33$ n. 3,34

1. $3: 25$

4. $4: 23,44$

16. 5: $25,102,105$ n. 30

Cleom.

2. $2: 25$

12. $4: 23$

37. $14: 33$

Comp. Cim. Luc.

1. $4: 25,42$

Cor.

1. $2: 87,93$

2: 83
3: 54

3. $1: 22$

4. $6: 93$

15. $7: 54$

33. $4: 16,91$

Dem.

4. 3: 100

4. $4: 36,92,102$ n. 26

4. $5: 36$

4. 6-7: 36 n. 5

5. 6: 93,100

22. $3: 90$ bis

26. 7: 83

Demetr.

2. 1: 94

3. $1: 51,91$ n. 21

3. 4: 91 n. 21

3. $5: 91 \mathrm{n} .21$

5. 3: $23,55,103,104$

6. $1: 55$

24. $3: 34,36$

24. 4: 105

24. $5: 33$ n. 3,34

38. $5: 89$

Dio

2. $4: 52$

4. 7:53

6. $4: 51$

7. $4: 44$

35. $6: 17$

55. $4: 21$

Eum.

1. 1: 102 n. 26

1. 2: 19

1-2: 102 bis, 103

1. 3: 96

13. $1: 96$ 
Fab.

22. 3: 25

Galb.

13. $4: 55$

16. 2: 103

19. $1: 44$

Luc.

1. 2-3: 82, 89

1. $4: 25$

9. $7: 17$

31. 3: 15

Lyc.

3: 94

3. $3: 14$

3. $5: 16$

11. 6: 60

12. $6: 71$

12. $12: 24$

14. 1: 64

14. $4: 72$

14. $5: 42$

14. $7: 72$

16. $1: 16,31$

16. $2: 31,110$ n. 2

16. 3: 87 n. 19

16. $4: 14,46$

16. $5: 87$

16. 6: 98

16. $7: 67,86,98$

16. $8: 68$

16. 10: 71

16. 11-14: 69

16-22: 66

17. 1: 106

17. 2: 68,69

17. $3: 68$

17. $4: 70$

17. 4-6: 69
17. $7: 70$

17. $8: 15,31$

18. $3: 70$

18. 3-5: 71

19. 5: 71

20. $14: 45$

21. $6: 71$

22: 70

22. $3: 70$

24: 68

25. 2: 106

26. $1: 17$

30. 7: 17, 99

Lys.

26. 1: 17

28. 7: 15,87 n. 19

Mar.

14. 4: 33

14. 5-6: 24

23. $1: 76$ bis

27. $2: 15$

34. 5: 75

40. 11-12: 35

46. 7: 23

Marc.

1. 4: 25

1. $5: 18$

2. $2: 49$

2. $3: 33$ n. 3,34

9. 7: 99

27. 3: 105 n. 30

Nic.

3. $4: 35$

11. 3: 23,45

12. $1: 23,102,107$

24. $1: 17$ 
Num.

8. 21: 50

Pel.

7. 1-2: 48

7. 5: 102,106 n. 31

8. $1: 48$

12. $6: 49$

19. 1: $60,102,105$

33. $4: 32$

33. $5: 24$

Per.

1. $1: 16$

4. 5: 80 n. 14

5. 1-2: 80 n. 14

39. $2: 36$

Phil.

1. 2: 21,96

1. $3: 80$

3. $2: 80$

3. $5: 81$

4. $1: 81$

4. $2: 79$

4. 7-8: 81

7. $5: 22$

11. $2: 25$

16: 67 n. 4

16. $8: 24$

Phoc.

4. 2: 101

6. $1: 55$

7. $3: 18,96$

7. $3-4: 56$

7. 4: 25

20. $1: 44$

20. 1, 4: 24

20. 4: 66
23. $2: 59$

23. 3: 46

Pom.

3. $1: 54$

6. 5: 57

8. 3: 57

8. 3 e $5: 23$

8. 4: 57

8. $5: 56$

8. $7: 28,58$

13. $5: 57$ n. 4

14. $1: 58$

14. $2: 58$

18. $1: 85$

29. 5: 50

37. 2: 90

40. 3: 24

53. $5: 16$

69. 5-6: 35

76. $7: 21$

Pyrrh.

1: 46

2. $1: 15$

26.18: 22

26. $21: 67$

28. 5: 35

30. $6: 25$

30.6-7: 24, 25

33. $2: 25$

Rom.

2-4: 110 n. 2

2. $7: 14,16$

3. $5: 14$

4. 1,2 e $4: 14$

6. 1: 14

6. $3: 41$

7. $5: 33,41$

8. $2: 16$ 
19. $2: 15,16$

20. $4: 19$ n. 3

21. $8: 15$

Sert.

2. 1: 51

2. $3: 82$

14. 3: 74

14. $4: 19$

Sol.

8. 5: 37,38

27. 7: 51 bis

Sull.

2. 6: 44

37. $6: 15$

TG

1. $7: 87,88$

Them.

1. 3: 102

2. $7: 25,59$

3. $2: 34$

10. 5: 101

12. $4: 100$

18. $2: 33$

26. 2: 100

Thes.

6. 2: 22

23. $2: 37,41$

23. $3: 37,38$

26. 3 e $5-7: 25$

Tim.

7. 5: 102

39. 6: 102 


\section{COLECÇÃo AUtores \\ GREgos E LATINos - SÉrIe ENSAIOS}

1. Carmen Soares, José Ribeiro Ferreira e Maria do Céu Fialho: Ética e Paideia em Plutarco (Coimbra, $\mathrm{CECH}, 2008)$.

2. Joaquim Pinheiro, José Ribeiro Ferreira, Nair Castro Soares, Rita Marnoto: Caminhos de Plutarco na Europa (Coimbra, CECH, 2011). 2a edição, revista e com um novo estudo.

3. Cláudia Teixeira, Delfim F. Leão and Paulo Sérgio Ferreira: The Satyricon of Petronius: Genre, Wandering and Style (Coimbra, CECH, 2008).

4. Teresa Carvalho, Carlos A. Martins de Jesus: Fragmentos de um Fascinio. Sete ensaios sobre a poesia de José Jorge Letria (Coimbra, CECH, 2009).

5. Delfim Ferreira Leão, José Ribeiro Ferreira e Maria do Céu Fialho: Cidadania e Paideia na Grécia Antiga (Coimbra, CECH, 2010).

6. Maria de Fátima Silva and Susana Hora Marques: Tragic Heroines on Ancient and Modern Stage (Coimbra, $\mathrm{CECH}, 2010)$.

7. Ália Rosa Rodrigues, Carlos A. Martins de Jesus, Rodolfo Lopes: Intervenientes, Discussão e Entretenimento, No Banquete de Plutarco (Coimbra, CECH, 2010). 
8. Luísa de Nazaré Ferreira, Paulo Simóes Rodrigues e Nuno Simóes Rodrigues: Plutarco e as Artes. Pintura, Cinema e Artes Decorativas (Coimbra, CECH, 2010).

9. Nair Castro Soares, Margarida Miranda, Carlota Miranda Urbano (Coord.): Homo eloquens homo politicus. A retórica e a construção da cidade na Idade Média e no Renascimento (Coimbra, CECH, 2011).

10. Carmen Soares: Crianças e jovens nas Vidas de Plutarco (Coimbra, CECH, 2011). 
IMPRESSÃO:

Simốes \& Linhares, Lda.

Av. Fernando Namora, n. ${ }^{\circ} 83$ - Loja 4

3000 CoImbra 
Os retratos de crianças e jovens delineados nas Vidas continuam, volvidos cerca de dezanove séculos sobre a sua redacção e salvas as diferenças decorrentes dos particularismos próprios de cada circunstância, a parecer familiares ao leitor contemporâneo. No geral, não despertam nele uma sensação de "estranhamento", mas sim de "reconhecimento".

Vemos, assim, uma vez mais confirmada a justeza de incluir Plutarco entre os grandes clássicos do pensamento universal. 